\title{
Cost-Effectiveness Analysis of the 2009 and 2012 IECC Residential Provisions - Technical Support Document
}

\author{
V Mendon \\ $R$ Lucas \\ $S$ Goel
}

April 2013

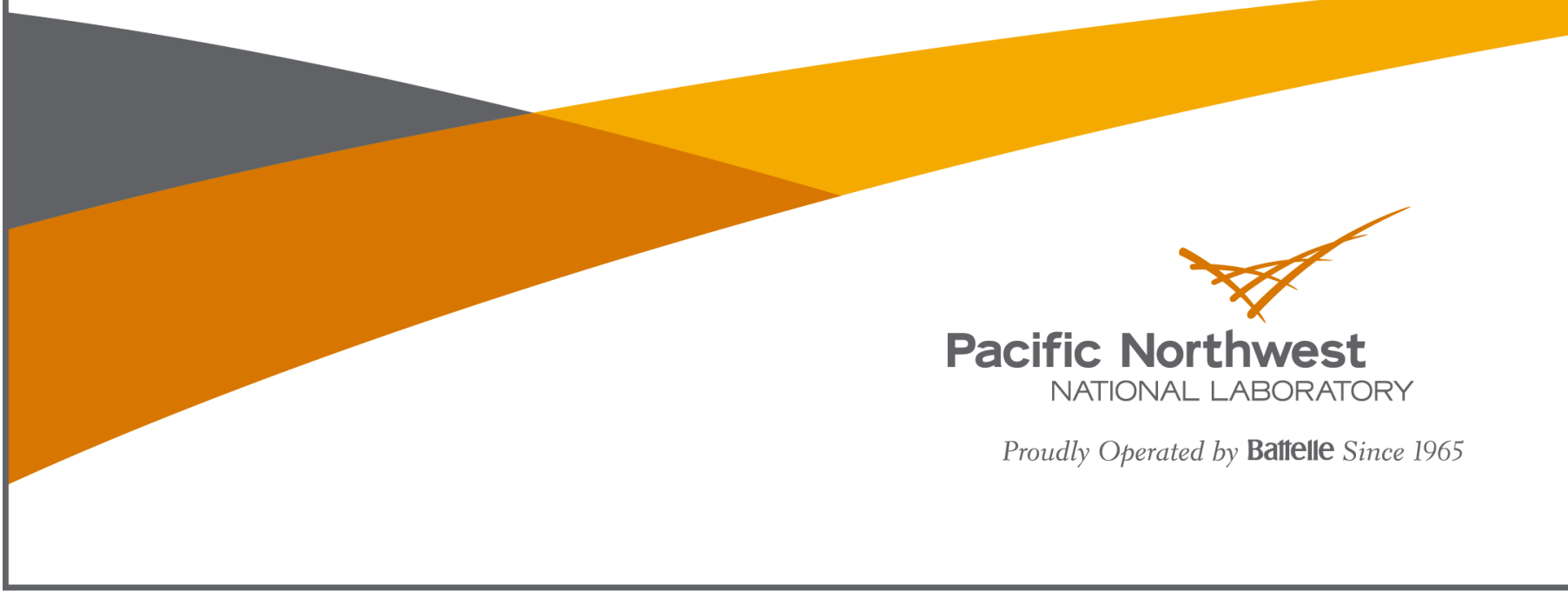




\title{
DISCLAIMER
}

This report was prepared as an account of work sponsored by an agency of the United States Government. Neither the United States Government nor any agency thereof, nor Battelle Memorial Institute, nor any of their employees, makes any warranty, express or implied, or assumes any legal liability or responsibility for the accuracy, completeness, or usefulness of any information, apparatus, produet, or process diselosed, or represents that its use would not infringe privately owned rights. Reference herein to any specific commercial product, process, or service by trade name, trademark, manufacturer, or otherwise does not necessarily constitute or imply its endorsement, recommendation, or favoring by the United States Government or any agency thereof, or Battelle Memorial Institute. The views and opinions of authors expressed herein do not necessarily state or reflect those of the United States Government or any agency thereof.

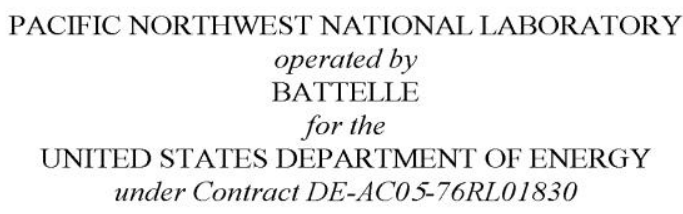

\section{Printed in the United States of America}

Available to DOE and DOE contractors from the Office of Scientific and Technical Information,

P.O. Box 62, Oak Ridge, TN 37831-0062;

ph: (865) 576-8401

fax: $(865) 576-5728$

email: reports@adonis.osti.gov

\author{
Available to the public from the National Technical Information Service, \\ U.S. Department of Commerce, 5285 Port Royal Rd., Springfield, VA 22161 \\ ph: (800) 553-6847 \\ fax: (703) 605-6900 \\ email: orders@ntis.fedworld.gov \\ online ordering: http://www.ntis.gov/ordering.htm
}

This document was printed on recycled paper

$(9 / 2003)$ 


\title{
Cost-Effectiveness Analysis of the 2009 and 2012 IECC Residential Provisions - Technical Support Document
}

\author{
V Mendon \\ R Lucas \\ $S$ Goel
}

April 2013

Prepared for

the U.S. Department of Energy

under Contract DE-AC05-76RL01830

Pacific Northwest National Laboratory

Richland, Washington 99352 


\section{Executive Summary}

This analysis was conducted by Pacific Northwest National Laboratory (PNNL) in support of the U.S. Department of Energy's (DOE) Building Energy Codes Program (BECP). DOE supports the development and adoption of energy efficient and cost-effective residential and commercial building energy codes. These codes set the minimum requirements for energy efficient building design and construction and ensure energy savings on a national level. This analysis focuses on one and two family dwellings, townhomes, and low-rise multifamily residential buildings. For these buildings, the basis of the energy codes is the International Energy Conservation Code (IECC). This report does not address commercial and high-rise residential buildings (four or more stories).

The IECC is developed and published on a three-year cycle, with a new version published at the end of each cycle. This analysis examines the 2006, 2009, and 2012 versions of the IECC as applied to individual states. Each version of the IECC includes provisions that increase energy-efficiency levels over its predecessor.

This report documents the analysis PNNL conducted to assess the cost effectiveness of the 2009 and 2012 IECC over the 2006 IECC at the state level. For each state, PNNL's analysis compares the newer version (or versions) of the IECC against an older version currently in use in the state. For states that have adopted the 2006 IECC or equivalent, the analysis evaluates the cost effectiveness of updating the state code to either the 2009 or 2012 IECC. For a state with a code already equivalent to the 2009 IECC, the analysis evaluates moving up to the 2012 IECC.

While some states adopt the IECC as published, other states amend the code. Still other states develop entirely unique state energy codes. Finally, some states have either no code at all or have a code based on a pre-2006 version of the IECC. PNNL conducted customized analyses for those states with amended IECC versions; assumed states with no code or an old code as using the 2006 IECC, and did not analyze state with custom codes.

DOE has established a methodology for determining energy savings and cost effectiveness of various building energy codes (Taylor et al. 2012). The methodology defines an analysis procedure including:

- Definitions of two building prototypes (single-family and multifamily)

- Identification of preferred calculation tools

- Climate locations

- Construction cost data sources

- Cost-effectiveness metrics and associated economic parameters

- Procedures for aggregating location-specific results to state, climate-zone, and national levels.

This technical support document provides additional detail and documents the specific assumptions used in applying the cost-effectiveness methodology. 
The analysis is conducted using DOE's EnergyPlus simulation software. PNNL developed two prototype building models to represent the single-family and the multifamily buildings defined in the methodology. These two prototypes were then expanded to a suite of 32 energy models to represent four commonly used heating systems in homes (i.e., gas furnace, oil furnace, heat pump, and electric furnace) and four commonly used foundations (i.e., vented crawlspace, slab-on-grade, heated basement, and unheated basement). Different versions of the models are created to match the requirements of the 2006, 2009, and 2012 IECC for each location. The entire set is simulated across 119 locations to represent the different climate-zone and moisture regimes in each state across the country.

The annual energy consumption for space heating, cooling, domestic hot water heating, and lighting is extracted for each case. The energy use is converted to energy cost using fuel costs in the different states. Incremental first costs are calculated for each location for the energy provisions of the 2009 and 2012 IECC over the baseline code, as applicable, using the Building Component Cost Community (BC3) data repository. ${ }^{1}$ These first costs are adjusted for variation in construction and material costs across the country using location multipliers developed by Faithful+Gould for PNNL. ${ }^{2}$ The energy costs and first costs are aggregated based on new housing construction starts from the U.S. Census data ${ }^{3}$, weights of the different foundation types from the Residential Energy Consumption Survey data ${ }^{4}$, and heating system weights based on National Association of Home Builders data (NAHB 2009). Life cycle cost (LCC) analysis is then conducted for each case to assess cost effectiveness. DOE uses LCC as the primary measure of cost effectiveness.

Table ES.1 shows the final energy cost savings results of the analysis. Table ES.2 summarizes the LCC savings results for each state. These data show that construction based on the 2009 and 2012 IECC results in greater energy savings than construction based on the 2006 IECC and is cost effective for all states.

Table ES.1. National Weighted Energy Cost Savings

\begin{tabular}{lcc}
\hline & 2009 IECC & 2012 IECC \\
\hline $\begin{array}{l}\text { National Energy Cost Savings over } \\
\text { the 2006 IECC }\end{array}$ & $10.8 \%(\$ 168)$ & $32.1 \%(\$ 500)$ \\
\hline
\end{tabular}

Table ES.2. State Life Cycle Cost Savings over the 2006 IECC (2012 dollars)

\begin{tabular}{|c|c|c|}
\hline \multirow[b]{2}{*}{ State } & \multicolumn{2}{|c|}{ Life Cycle Cost Savings over the 2006 IECC (\$) } \\
\hline & 2009 IECC & 2012 IECC \\
\hline Alabama & 2,117 & 6,182 \\
\hline Alaska & 5,861 & 20,745 \\
\hline Arizona & 3,245 & 6,550 \\
\hline
\end{tabular}

\footnotetext{
${ }^{1}$ http://bc3.pnnl.gov/wiki/index.php/Main_Page.

${ }^{2}$ http://bc3.pnnl.gov/wiki/images/7/7f/Location_Factors_Report.pdf.

${ }^{3}$ United States Census Bureau Building Permits; Accessed April 27, 2012 at http://censtats.census.gov/bldg/bldgprmt.shtml.

${ }^{4} 2009$ RECS Survey Data 'Structural and Geographic Characteristics' http://www.eia.gov/consumption/residential/data/2009/\#undefined.
} 
Table ES.2. (contd)

\begin{tabular}{|c|c|c|}
\hline \multirow[b]{2}{*}{ State } & \multicolumn{2}{|c|}{ Life Cycle Cost Savings over the 2006 IECC (\$) } \\
\hline & 2009 IECC & 2012 IECC \\
\hline Arkansas & 1,948 & 6,679 \\
\hline California & 1,192 & 2,136 \\
\hline Colorado & 1,528 & 5,435 \\
\hline Connecticut & 3,793 & 13,709 \\
\hline Delaware & 4,316 & 14,778 \\
\hline District of Columbia & 2,024 & 6,852 \\
\hline Florida & 2,320 & 4,147 \\
\hline Georgia & 2,210 & 6,415 \\
\hline Hawaii & 5,150 & 14,238 \\
\hline Idaho & 1,444 & 5,515 \\
\hline Illinois & 1,784 & 6,506 \\
\hline Indiana & 1,781 & 6,764 \\
\hline Iowa & 2,823 & 10,416 \\
\hline Kansas & 2,556 & 8,828 \\
\hline Kentucky & 2,279 & 7,646 \\
\hline Louisiana & 1,663 & 4,107 \\
\hline Maine & 5,109 & 18,944 \\
\hline Maryland & 3,473 & 11,688 \\
\hline Massachusetts & 3,914 & 14,777 \\
\hline Michigan & 3,363 & 12,346 \\
\hline Minnesota & 3,196 & 11,817 \\
\hline Mississippi & 2,022 & 5,400 \\
\hline Missouri & 2,229 & 7,826 \\
\hline Montana & 1,668 & 5,920 \\
\hline Nebraska & 1,908 & 7,141 \\
\hline Nevada & 2,543 & 7,352 \\
\hline New Hampshire & 3,925 & 14,573 \\
\hline New Jersey & 3,445 & 11,877 \\
\hline New Mexico & 1,835 & 5,897 \\
\hline New York & 3,870 & 13,677 \\
\hline North Carolina & 1,844 & 5,911 \\
\hline North Dakota & 2,353 & 8,719 \\
\hline Ohio & 1,959 & 7,120 \\
\hline Oklahoma & 2,526 & 8,621 \\
\hline Oregon & 1,422 & 4,917 \\
\hline Pennsylvania & 3,189 & 11,845 \\
\hline Rhode Island & 4,043 & 15,074 \\
\hline South Carolina & 2,215 & 6,650 \\
\hline South Dakota & 2,583 & 9,514 \\
\hline Tennessee & 1,809 & 6,102 \\
\hline
\end{tabular}


Table ES.2. (contd)

\begin{tabular}{lcc}
\hline & \multicolumn{2}{c}{ Life Cycle Cost Savings over the 2006 IECC $(\$)$} \\
\cline { 2 - 3 } \multicolumn{1}{c}{ State } & 2009 IECC & 2012 IECC \\
\hline Texas & 2,433 & 5,942 \\
Utah & 1,385 & 4,879 \\
Vermont & 5,133 & 18,861 \\
Virginia & 2,186 & 7,487 \\
Washington & 1,498 & 5,299 \\
West Virginia & 1,996 & 7,301 \\
Wisconsin & 3,056 & 11,272 \\
Wyoming & 1,809 & 6,441 \\
\hline
\end{tabular}




\section{Acronyms and Abbreviations}

$\mathrm{ACH} 50$

ANSI

ASHRAE

$\mathrm{BC} 3$

BECP

CFL

CFM

DOE

ECPA

EF

ELA

HVAC

ICC

IECC

IES

IMC

IRC

LCC

PNNL

SHGC

TMY

U-factor

WFR

WHAM

WWR
50-Pa pressure differential

American National Standards Institute

American Society of Heating, Refrigerating, and Air-Conditioning Engineers

Building Component Cost Community

Building Energy Codes Program

compact fluorescent lamp

cubic feet per minute

U.S. Department of Energy

Energy Conservation and Production Act

Energy Factor

effective leakage area

heating, ventilation, and air conditioning

International Code Council

International Energy Conservation Code

Illuminating Engineering Society of North America

International Mechanical Code

International Residential Code

life cycle cost

Pacific Northwest National Laboratory

solar heat gain coefficient

Typical Meteorological Year

effective thermal conductance

window-to-floor ratio

Water Heater Analysis Model

window-to-wall ratio 


\section{Contents}

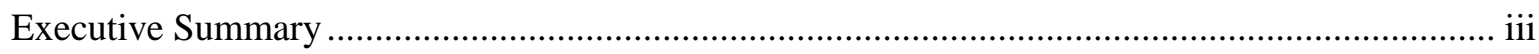

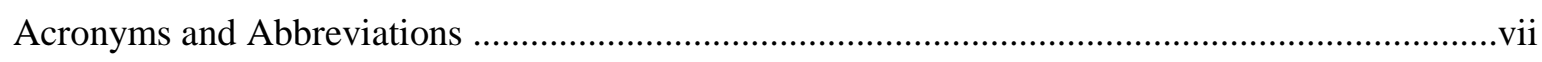

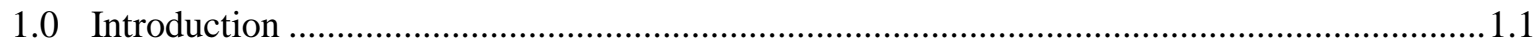

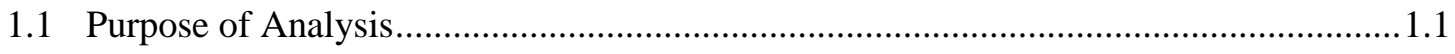

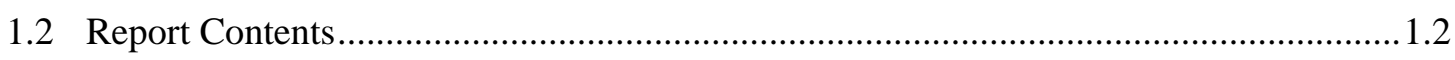

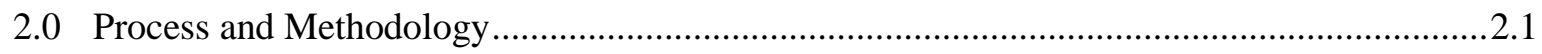

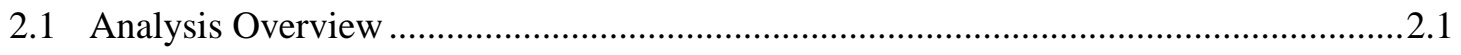

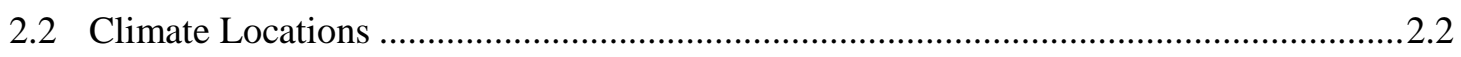

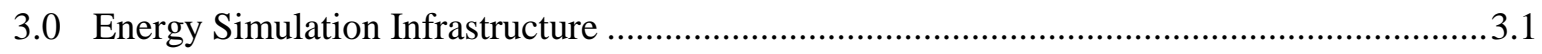

4.0 Prototype Building Models.......................................................................................... 4.1

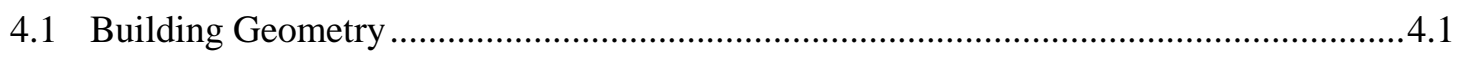

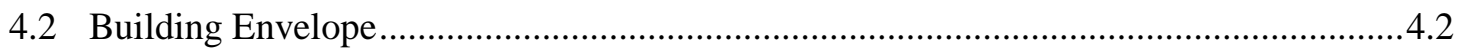

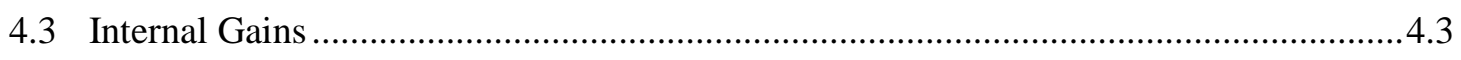

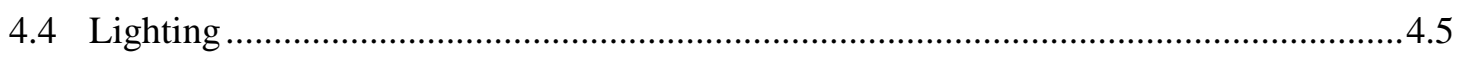

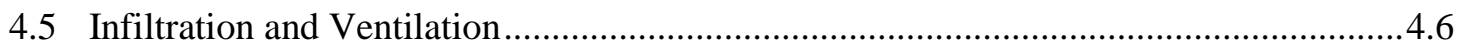

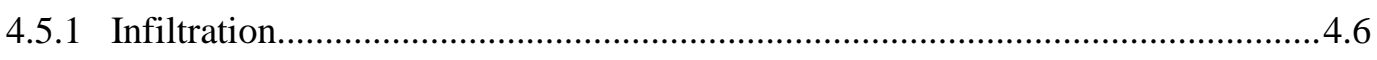

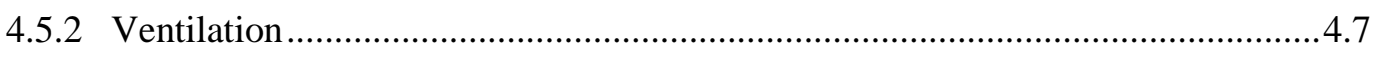

4.6 Heating, Ventilation, and Air-Conditioning Systems .............................................. 4.8

4.6.1 Operating Conditions ............................................................................... 4.8

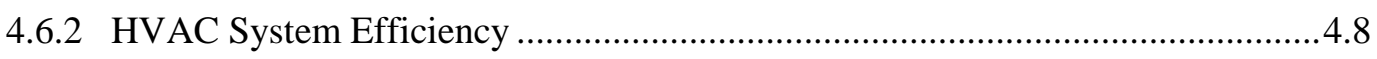

4.6.3 Air Distribution System and Duct Leakage Rates.............................................. 4.9

4.7 Domestic Hot Water System ................................................................................. 4.9

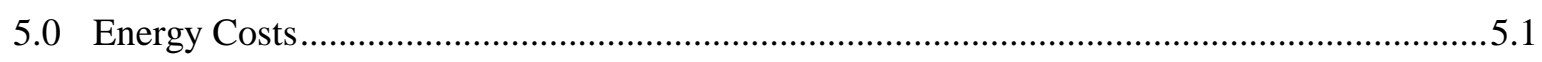

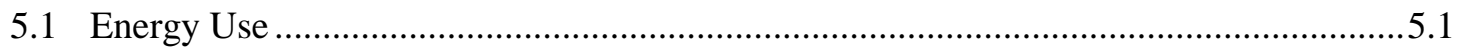

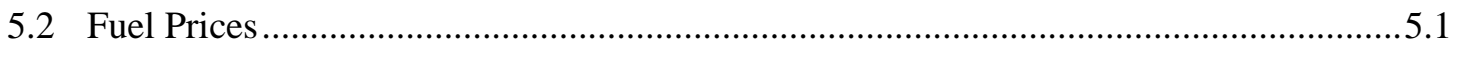

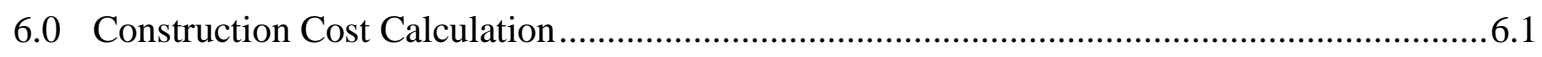

6.1 Requirements by Climate Zone for Each Code Level................................................. 6.1

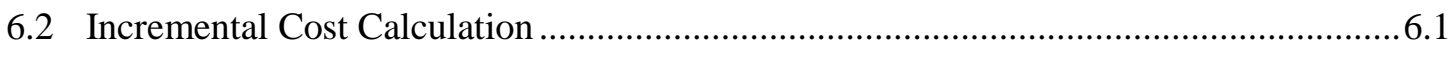

6.2.1 Duct Testing and Improved Duct Sealing ...................................................... 6.1

6.2.2 Building Envelope Testing and Improved Envelope Sealing..............................6.4

6.2.3 Window Improvements (U-Factor and Solar Heat Gain Reduction) ...................6.4

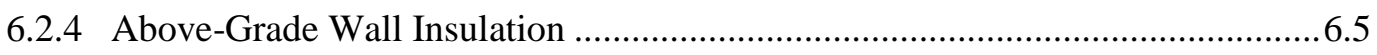

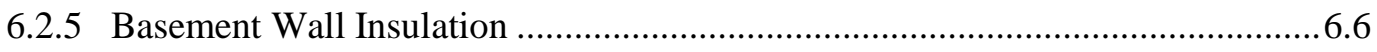

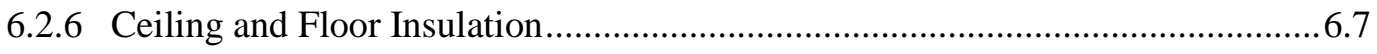

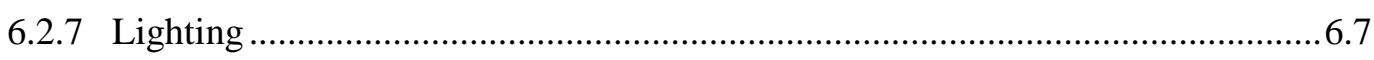

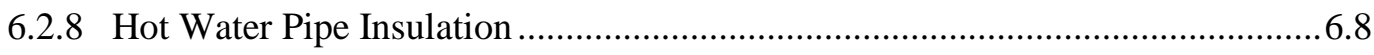


6.2.9 Total Incremental Construction Costs - 2006 to 2009 IECC ...............................6.8

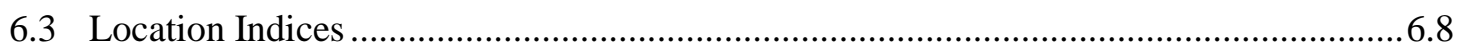

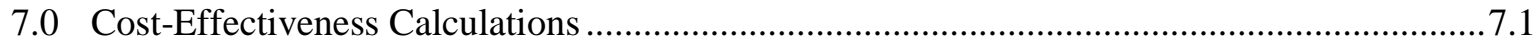

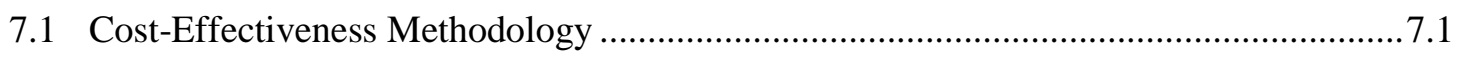

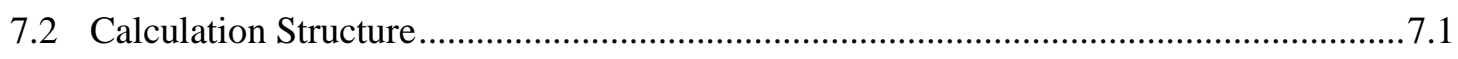

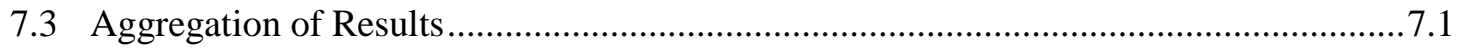

7.3.1 Aggregation Across Foundation Types ......................................................... 7.3

7.3.2 Aggregation Across Heating System Types ...................................................... 7.4

7.3.3 Aggregation Across Building Types ............................................................... 7.5

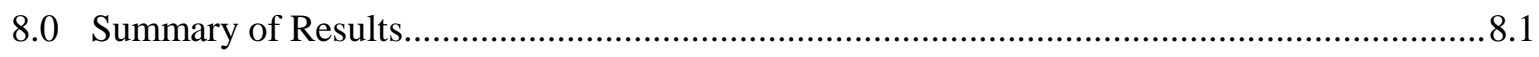

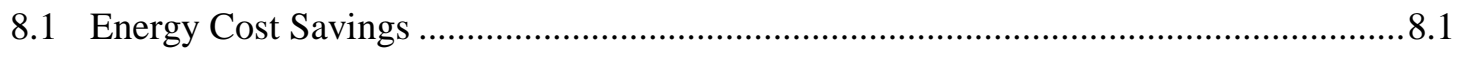

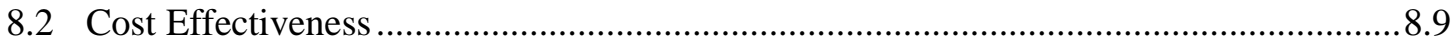

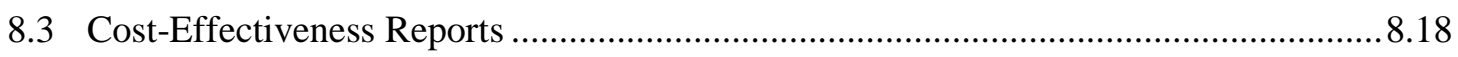

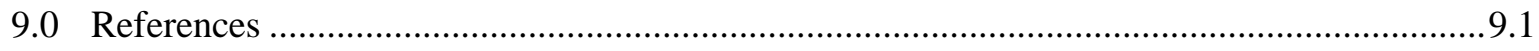

Appendix A - Building Energy Model Description ............................................................... A.1

Appendix B - Major Prescriptive Code Requirements for the 2006 IECC, the 2009 IECC, and the

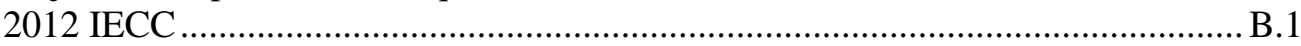

Appendix C - Custom State Requirements and Analyses ..................................................... C.1 


\section{Figures}

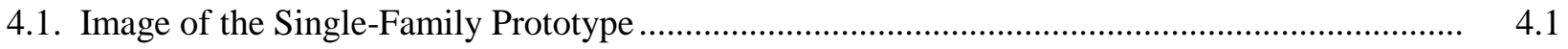

4.2. Image of the Multifamily Prototype.....................................................................................

4.3. Plan View Showing Prototype Central Breezeway ................................................................... 4.2

7.1. Overview of the Aggregation Process ................................................................................

\section{Tables}

ES.1 National Weighted Energy Cost Savings ............................................................................ iv

ES.2 State Life Cycle Cost Savings over the 2006 IECC ........................................................... iv

2.1. Locations for Cost-Effectiveness Analysis ........................................................................ 2.2

4.1. Internal Gains for Single-Family and Multifamily Prototypes as Specified by the 2006 IECC ... 4.3

4.2. Breakdown of Internal Gains for the Single-Family Prototype .............................................. 4.4

4.3. Breakdown of Internal Gains for the Multifamily Prototype ....................................................

4.4. Baseline Lighting Energy Use for the 2006 IECC .................................................................. 4.5

4.5. Lighting fixture type fractions for the 2006, 2009 and 2012 IECC ....................................... 4.5

4.6. Air Changes at $50 \mathrm{~Pa}$ and Effective Leakage Area by IECC Version ...................................... 4.7

4.7. Outdoor Air Flow Rates Used in Simulations ........................................................................ 4.7

4.8. Heating and Cooling Equipment Efficiencies used in this Analysis........................................ 4.8

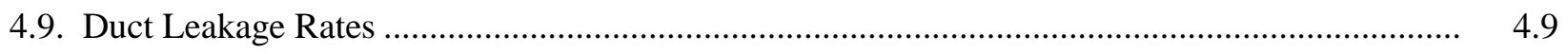

4.10. Water Heater Energy Factor used in the Analysis ................................................................ 4.10

4.11. Standby Losses and Burner Thermal Efficiencies for Water Heaters..................................... 4.10

5.1. Fuel Prices by State.................................................................................................

6.1. Prescriptive Code Requirements that Vary by Climate Zone …............................................... 6.2

6.2. Major Code Requirements that do not Vary by Climate Zone .............................................. 6.3

6.3. U-Factor and SHGC Requirements for Windows in the 2006, 2009, and 2012 IECC ............... 6.5

6.4. Incremental Costs for the 2009 IECC over the 2006 IECC for the Single-Family Prototype ...... 6.9

6.5. Incremental Costs for the 2009 IECC over the 2006 IECC for the Multifamily Prototype......... 6.10

6.6. Incremental Costs for the 2012 IECC over the 2009 IECC for the Single-Family Prototype ...... 6.11

6.7. Incremental Costs for the 2012 IECC over the 2009 IECC for the Multifamily Prototype.......... 6.11

6.8. Construction Cost Multiplier by State ................................................................................. 6.12

7.1. Economic Parameters Used in LCC Calculations.................................................................

7.2. Percent Shares of Foundation Types..................................................................................

7.3. Share of Heating Systems - Single-Family Home (percent) …..............................................

7.4. Share of Heating Systems - Multifamily Home (percent) …...................................................

7.5. New Housing Construction Starts from the 2010 Census Data ................................................ 
8.1. National Energy Cost Savings for the 2009 and 2012 IECC Compared to the 2006 IECC

8.2. Energy Cost Savings by Climate Zone for the 2009 and 2012 IECC Compared to the 2006 IECC

8.3. Energy Cost Savings by State and Climate Zone for the 2009 and 2012 IECC Compared to the 2006 IECC

8.4. National Energy Cost Savings for the 2012 IECC Compared to the 2009 IECC

8.5. Energy Cost Savings by Climate Zone for the 2012 IECC Compared to the 2009 IECC.

8.6. Energy Cost Savings by State and Climate Zone for the 2009 and 2012 IECC Compared to the 2006 IECC

8.7. Life Cycle Cost Savings by Climate Zone for the 2009 and 2012 IECC Compared to the 2006 IECC (2012 dollars)

8.8. Life Cycle Cost Savings by State and Climate Zone for the 2009 and 2012 IECC Compared to the 2006 IECC (2012 dollars).

8.9. Life Cycle Cost Savings by State and Climate Zone for the 2012 IECC Compared to the 2009 IECC (2012 dollars). 


\subsection{Introduction}

The U.S. Department of Energy (DOE) supports the development and adoption of building codes that promote energy efficiency. Title III of the Energy Conservation and Production Act (ECPA), as amended, mandates that DOE participate in the development of model building energy codes and assist states in adopting and implementing these codes. The designated residential model energy code is the International Energy Conservation Code (IECC) published by the International Code Council (ICC).

This report documents the methodology and assumptions used in a state-by-state analysis of two recent versions of the IECC (2009 and 2012) conducted by the Pacific Northwest National Laboratory (PNNL) in support of the DOE's Building Energy Codes Program (BECP). The analysis and associated methodology cover single-family detached homes and low-rise multifamily buildings.

\subsection{Purpose of Analysis}

The IECC is developed and published on a three-year cycle, with a new version published at the end of each cycle. This analysis examines the 2006, 2009, and 2012 versions of the IECC as applied to individual states. These versions are referred to as the 2006 IECC, the 2009 IECC, and the 2012 IECC in this report. Each version of the IECC includes provisions that increase energy-efficiency levels over its predecessor. For each state, PNNL's analysis compares the newer version (or versions) of the IECC against an older version currently in use in the state. For states that have adopted the 2006 IECC or an equivalent code, the analysis evaluates the cost effectiveness of updating the state code to either the 2009 or 2012 IECC. For a state with a code already equivalent to the 2009 IECC, the analysis evaluates energy efficiency-improvements that would be realized by adopting the 2012 IECC.

Not all states adopt the IECC directly. Some states adopt amended versions, some develop custom state codes, and some have either no code or an older code based on a pre-2006 IECC. PNNL conducted customized analyses for those states with amended versions of the IECC and assumed homes in states with no code or an older code are built to a level of energy efficiency equivalent to the 2006 IECC. PNNL did not analyze custom state codes that are not based on the IECC.

DOE has established a methodology for determining energy savings and cost effectiveness of various building energy codes (Taylor et al. 2012). The methodology, hereafter referred to as the costeffectiveness methodology, is available for download from DOE's energy codes website. ${ }^{1}$ The costeffectiveness methodology defines an energy analysis procedure, including definitions of two building prototypes (single-family and multifamily), identification of preferred calculation tools, and selection of climate locations to be analyzed; establishes preferred construction cost data sources; defines costeffectiveness metrics and associated economic parameters; and defines a procedure for aggregating location-specific results to state, climate-zone, and national levels. This technical support document provides additional detail and documents the specific assumptions used in applying the cost-effectiveness methodology.

\footnotetext{
${ }^{1}$ http://www.energycodes.gov/development/residential/methodology.
} 


\subsection{Report Contents}

This report documents the process of evaluating energy cost savings and cost effectiveness of newer versions of the IECC relative to an older version. Energy savings are computed using energy simulations of two base residential building prototypes - a single-family detached home and a low-rise multifamily building. These two prototypes are simulated using four different heating systems (i.e., gas furnace, heat pump, oil furnace, and electric furnace) and four different foundation types (i.e., vented crawlspace, slabon-grade, heated basement, and unheated basement) to represent typical residential new-construction stock. These options result in an expanded set of 32 models that are simulated across 119 representative climate locations, yielding a set of 3808 building-energy models for each analyzed version of the IECC.

The energy savings results and the associated incremental costs for each case are aggregated to state, climate zones and national levels using U.S. Census data on new housing construction starts. ${ }^{1}$ A costeffectiveness analysis is carried out to determine three cost-effectiveness metrics-life-cycle cost (LCC), simple payback period, and consumer cash flow—for each analyzed version of the IECC.

This report is divided into three parts. Part one (Chapters 2 through 5) provides details on the energy modeling and assumptions. Part two (Chapters 6 and 7) details the incremental cost calculation for each location, economic calculations, and the aggregation scheme for generating state and national average energy cost savings and cost effectiveness results. Finally, part three (Chapter 8) summarizes state and national energy cost savings and cost effectiveness results. These final results also are published as a part of the individual state and national cost effectiveness reports. ${ }^{2}$

More details are provided in the appendices. Appendix A provides detailed modeling assumptions and prototype descriptions used in the energy simulations, including internal heat gains assumptions, and various schedules. Appendix B lays out the prescriptive code requirements of the 2006, 2009, and 2012 IECC. Finally, Appendix C describes prescriptive code requirements for states with amended versions of the IECC that are modeled in the customized state analyses.

\footnotetext{
${ }^{1}$ United States Census Bureau Building Permits; Accessed April 27, 2012 http://censtats.census.gov/bldg/bldgprmt.shtml.

${ }^{2}$ Residential IECC Cost Effectiveness Analysis and Results http://www.energycodes.gov/development/residential/iecc_analysis.
} 


\subsection{Process and Methodology}

\subsection{Analysis Overview}

The 2009 and 2012 IECC include provisions that promote substantial improvements in energy efficiency compared to the 2006 IECC. The focus of this analysis is assessing the energy savings and cost effectiveness of the two newer versions of the IECC for typical single-family detached homes and low-rise multifamily buildings, and aggregating those results to appropriate state and/or national levels. The sequence of operations for a given state is described below:

1. Identify the relevant state code and any state-specific amendments. This establishes the baseline code for the state and determines whether both the 2009 and 2012 IECC will be analyzed (if the 2006 IECC is the baseline) or just the 2012 IECC (if the 2009 IECC is the baseline).

2. Assemble construction cost data for the building elements that have changed between the baseline code and the analyzed code(s). Apply regional adjustments to these national average costs so they represent the specific locations analyzed.

3. Simulate the energy differences (savings) between the baseline code and the newer code(s) for each of the climate locations.

4. Aggregate energy savings and incremental costs to state, climate-zone, and national levels and calculate cost-effectiveness metrics (e.g., LCC, payback period, consumer cash flow, etc.) for each new code.

Annual energy use for each case is simulated using DOE's EnergyPlus ${ }^{\mathrm{TM}}$ software, Version 5.0. ${ }^{1}$ The cost-effectiveness methodology defines details of the single-family and multifamily prototype buildings such as typical constructions, mechanical systems, internal gains and operating assumptions. The building prototypes include four foundation types and four heating system types to appropriately account for location-specific construction practices and fuel usage. The energy results are aggregated across building types, foundation types, heating equipment types, and locations using weighting factors defined in the cost-effectiveness methodology to provide national, climate-zone-specific, and state-specific energy cost savings.

The cost effectiveness of code changes is determined using energy cost savings from the improvements in the code(s) and the associated incremental first cost of construction. Incremental first costs of energy efficient code changes are determined through several sources as detailed in subsequent chapters. Location-specific cost multipliers are used to account for regional variations in construction costs. Location-specific fuel prices are taken from the most recent state-specific residential fuel prices available from DOE's Energy Information Administration. . 2,3,4

\footnotetext{
${ }^{1}$ EnergyPlus at http://apps1.eere.energy.gov/buildings/energyplus.

${ }^{2}$ U.S. Department of Energy (DOE). 2012a. Electric Power Monthly. DOE/EIA-0226. Washington, D.C. http://www.eia.doe.gov/cneaf/electricity/epm/table5_6_a.html

${ }^{3}$ U.S. Department of Energy (DOE). 2012b. Natural Gas Monthly. DOE/EIA-0130. Washington, D.C. http://www.eia.gov/oil_gas/natural_gas/data_publications/natural_gas monthly/ngm.html

${ }^{4}$ U.S. Department of Energy (DOE). 2012c. Petroleum Marketing Monthly. DOE/EIA-0380. Washington, D.C. http://www.eia.gov/petroleum/marketing/monthly/
} 


\subsection{Climate Locations}

The cost-effectiveness methodology details the selection of the climate locations used in this analysis. In each state, one representative climate location is chosen for each unique combination of climate zone 1 through 8 and moisture regime - moist, dry, marine, and warm-humid. This results in 119 weather locations that are used in the analysis. Table 2.1 lists these locations.

To simulate energy use for each case, the latest Typical Meteorological Year weather files (TMY3) ${ }^{1}$ are used with EnergyPlus. The TMY3 dataset contains 1020 locations nationwide, including Guam, Puerto Rico, and the U.S. Virgin Islands. However, a complete TMY3 file is not available for some stateclimate zone combinations. In these cases, professional judgment is used to select a best representative TMY3 data location outside the state.

Table 2.1. Locations for Cost-Effectiveness Analysis

\begin{tabular}{lccl}
\hline \multicolumn{1}{c}{ State } & Climate Zone & Moisture Regime ${ }^{(\text {a) }}$ & \multicolumn{1}{c}{ Location } \\
\hline Alabama & 2 & A, WH & Mobile \\
Alabama & 3 & A & Birmingham \\
Alabama & 3 & A, WH & Montgomery \\
Alaska & 7 & & Anchorage \\
Alaska & 8 & & Fairbanks \\
Arizona & 2 & B & Phoenix \\
Arizona & 3 & B & Kingman \\
Arizona & 4 & B & Prescott \\
Arizona & 5 & B & Winslow \\
Arkansas & 3 & A & Little Rock \\
Arkansas & 3 & A, WH & Shreveport (Louisiana) \\
Arkansas & 4 & A & Springfield (Missouri) \\
California & 2 & B & Tucson (Arizona) \\
California & 3 & B & Los Angeles \\
California & 3 & C & San Francisco \\
California & 4 & B & Sacramento \\
California & 4 & C & Arcata \\
California & 5 & B & Reno (NV) \\
California & 6 & B & Eagle \\
Colorado & 4 & B & Trinidad \\
Colorado & 5 & B & Colorado Springs \\
Colorado & 6 & B & Eagle County \\
Colorado & 7 & & Gunnison County \\
Connecticut & 5 & A & Hartford-Bradley \\
Delaware & 4 & & Wilmington \\
& & & \\
\hline & 5 & & \\
\hline
\end{tabular}

\footnotetext{
${ }^{1}$ National Solar Radiation Data Base. 1991-2005 Update: Typical Meteorological Year 3. Accessed April 27, 2012 at http://rredc.nrel.gov/solar/old_data/nsrdb/1991-2005/tmy3/.
} 
Table 2.1. (contd)

\begin{tabular}{|c|c|c|c|}
\hline State & Climate Zone & Moisture Regime $^{(\mathrm{a})}$ & Location \\
\hline District of Columbia & 4 & $\mathrm{~A}$ & Baltimore (Maryland) \\
\hline Florida & 1 & $\mathrm{~A}, \mathrm{WH}$ & Miami \\
\hline Florida & 2 & $\mathrm{~A}, \mathrm{WH}$ & Tampa \\
\hline Georgia & 2 & $\mathrm{~A}, \mathrm{WH}$ & Savannah \\
\hline Georgia & 3 & A & Atlanta \\
\hline Georgia & 3 & $\mathrm{~A}, \mathrm{WH}$ & Macon \\
\hline Georgia & 4 & A & Chattanooga (Tennessee) \\
\hline Hawaii & 1 & A & Honolulu \\
\hline Idaho & 5 & B & Boise \\
\hline Idaho & 6 & B & Pocatello \\
\hline Illinois & 4 & A & St. Louis (Missouri) \\
\hline Illinois & 5 & A & Peoria \\
\hline Indiana & 4 & A & Evansville \\
\hline Indiana & 5 & A & Indianapolis \\
\hline Iowa & 5 & A & Des Moines \\
\hline Iowa & 6 & A & Mason City \\
\hline Kansas & 4 & A & Topeka \\
\hline Kansas & 5 & A & Goodland \\
\hline Kentucky & 4 & A & Lexington \\
\hline Louisiana & 2 & $\mathrm{~A}, \mathrm{WH}$ & Baton Rouge \\
\hline Louisiana & 3 & A & Monroe \\
\hline Louisiana & 3 & $\mathrm{~A}, \mathrm{WH}$ & Shreveport \\
\hline Maine & 6 & A & Portland \\
\hline Maine & 7 & & Caribou \\
\hline Maryland & 4 & A & Baltimore \\
\hline Maryland & 5 & A & Harrisburg (Pennsylvania) \\
\hline Massachusetts & 5 & A & Boston-Logan \\
\hline Michigan & 5 & A & Lansing \\
\hline Michigan & 6 & A & Alpena County \\
\hline Michigan & 7 & & Sault Ste. Marie \\
\hline Minnesota & 6 & A & Minneapolis-St. Paul. \\
\hline Minnesota & 7 & & Duluth \\
\hline Mississippi & 2 & $\mathrm{~A}, \mathrm{WH}$ & Mobile (Alabama) \\
\hline Mississippi & 3 & A & Tupelo \\
\hline Mississippi & 3 & $\mathrm{~A}, \mathrm{WH}$ & Jackson \\
\hline Missouri & 4 & A & St. Louis \\
\hline Missouri & 5 & A & Kirksville \\
\hline Montana & 6 & B & Helena \\
\hline Nebraska & 5 & A & Omaha \\
\hline Nevada & 3 & B & Las Vegas \\
\hline
\end{tabular}


Table 2.1. (contd)

\begin{tabular}{|c|c|c|c|}
\hline State & Climate Zone & Moisture Regime ${ }^{(\mathrm{a})}$ & Location \\
\hline Nevada & 5 & $\mathrm{~B}$ & Reno \\
\hline New Hampshire & 5 & A & Manchester \\
\hline New Hampshire & 6 & A & Concord \\
\hline New Jersey & 4 & A & Newark \\
\hline New Jersey & 5 & A & Allentown (Pennsylvania) \\
\hline New Mexico & 3 & B & Lubbock (Texas) \\
\hline New Mexico & 4 & B & Albuquerque \\
\hline New Mexico & 5 & B & Winslow (Arizona) \\
\hline New York & 4 & A & New York \\
\hline New York & 5 & A & Albany \\
\hline New York & 6 & A & Binghamton \\
\hline North Carolina & 3 & $\mathrm{~A}$ & Charlotte \\
\hline North Carolina & 3 & $\mathrm{~A}, \mathrm{WH}$ & Wilmington \\
\hline North Carolina & 4 & A & Raleigh \\
\hline North Carolina & 5 & A & Elkins (West Virginia) \\
\hline North Dakota & 6 & A & Bismarck \\
\hline North Dakota & 7 & & Minot \\
\hline Ohio & 4 & A & Cincinnati (Kentucky) \\
\hline Ohio & 5 & A & Columbus \\
\hline Oklahoma & 3 & A & Oklahoma \\
\hline Oklahoma & 4 & B & Amarillo (Texas) \\
\hline Oregon & 4 & $\mathrm{C}$ & Portland \\
\hline Oregon & 5 & B & Redmond \\
\hline Pennsylvania & 4 & A & Philadelphia \\
\hline Pennsylvania & 5 & A & Harrisburg. \\
\hline Pennsylvania & 6 & A & Bradford \\
\hline Rhode Island & 5 & A & Providence- \\
\hline South Carolina & 3 & A & Columbia \\
\hline South Carolina & 3 & $\mathrm{~A}, \mathrm{WH}$ & Charleston \\
\hline South Dakota & 5 & A & Sioux City (Iowa) \\
\hline South Dakota & 6 & A & Pierre \\
\hline Tennessee & 3 & A & Memphis \\
\hline Tennessee & 4 & A & Nashville \\
\hline Texas & 2 & $\mathrm{~A}, \mathrm{WH}$ & Houston \\
\hline Texas & 2 & $\mathrm{~B}, \mathrm{WH}$ & San Antonio \\
\hline Texas & 3 & A & Wichita Falls \\
\hline Texas & 3 & $\mathrm{~A}, \mathrm{WH}$ & Fort Worth-Alliance. \\
\hline Texas & 3 & B & El Paso \\
\hline Texas & 4 & B & Amarillo \\
\hline Utah & 3 & B & Saint George \\
\hline Utah & 5 & B & Salt Lake City \\
\hline Utah & 6 & B & Vernal \\
\hline
\end{tabular}


Table 2.1. (contd)

\begin{tabular}{lccl}
\hline \multicolumn{1}{c}{ State } & Climate Zone & Moisture Regime $^{(\mathrm{a})}$ & \multicolumn{1}{c}{ Location } \\
\hline Vermont & 6 & $\mathrm{~A}$ & Burlington \\
Virginia & 4 & A & Richmond \\
Washington & 4 & C & Seattle \\
Washington & 5 & B & Spokane \\
Washington & 6 & B & Kalispell (Montana) \\
West Virginia & 4 & A & Charleston \\
West Virginia & 5 & A & Elkins \\
Wisconsin & 6 & A & Madison \\
Wisconsin & 7 & & Duluth (Minnesota) \\
Wyoming & 5 & B & Scottsbluff (Nebraska) \\
Wyoming & 6 & B & Cheyenne \\
Wyoming & 7 & & Jackson Hole \\
\hline
\end{tabular}

(a) Moisture zone designations are defined as follows:

$$
\begin{aligned}
& \mathrm{A}=\text { Moist } \\
& \mathrm{B}=\text { Dry } \\
& \mathrm{C}=\text { Marine } \\
& \mathrm{WH}=\text { Warm-Humid. }
\end{aligned}
$$

Climate zones 7 and 8 have no moisture designations in the code. 


\subsection{Energy Simulation Infrastructure}

Energy savings estimates are generated using DOE's EnergyPlus, version 5.0, simulation software. The two prototype building models (i.e., single-family detached home and low-rise multifamily apartment building) are simulated with four heating systems and four foundation types, resulting in 32 separate models for each of three IECC versions. These 96 models are simulated in each of the 119 locations for a total of 11,424 EnergyPlus simulations for the entire national analysis.

The numerous input files (EnergyPlus Input Data Files-IDF) are generated using a PNNL in-house utility that combines a generic input data file template with a large table of input parameters. The generated files are executed in batch style on a Linux computer cluster and managed with the Make ${ }^{1}$ utility to minimize the need for manual intervention to synchronize output files with input files. Custom post-processing scripts written in the Perl ${ }^{2}$ language are used to automate the process of retrieving key values from the simulation outputs and forwarding them to a statistical analysis software package for calculating the cost-effectiveness metrics and aggregating results to appropriate levels.

The simulation input and output files are available for download from DOE's Energy Codes website at http://www.energycodes.gov/development/residential/iecc_models.

\footnotetext{
${ }^{1}$ Make http://www.gnu.org/software/make/.

${ }^{2}$ Perl http://www.perl.org/.
} 


\subsection{Prototype Building Models}

The single-family and multifamily prototype building models are intended to represent residential new-construction stock. The cost-effectiveness methodology defines the major elements that characterize these prototypes and the relevant code's primary prescriptive manifestation defines the prototypes' envelope efficiencies in each location of interest. Appendix A summarizes those characteristics along with numerous additional details required to assemble complete EnergyPlus input files for the various simulations. It also provides details on internal gains assumptions and calculations and includes schedules used in the energy simulations. Two electronic spreadsheets, known as scorecards ${ }^{1}$ which contain key modeling assumptions and inputs for the two prototypes, are available on DOE's energy codes website. ${ }^{2}$ All 11,424 EnergyPlus input files and associated output files from this analysis also are available for download on the same website. ${ }^{2}$

\subsection{Building Geometry}

The single-family prototype is configured as a $2400 \mathrm{ft}^{2}$, two-story detached home with one of four different foundation types. The house is divided into either two or three thermal zones based on the foundation type. All models contain a living space zone and an attic zone; an additional foundation zone is added for models with a crawlspace or basement foundation. Figure 4.1 shows a snapshot of the single-family model with a crawlspace extracted from OpenStudio ${ }^{3}$, which is an EnergyPlus plug-in for the SketchUp ${ }^{4}$ software.

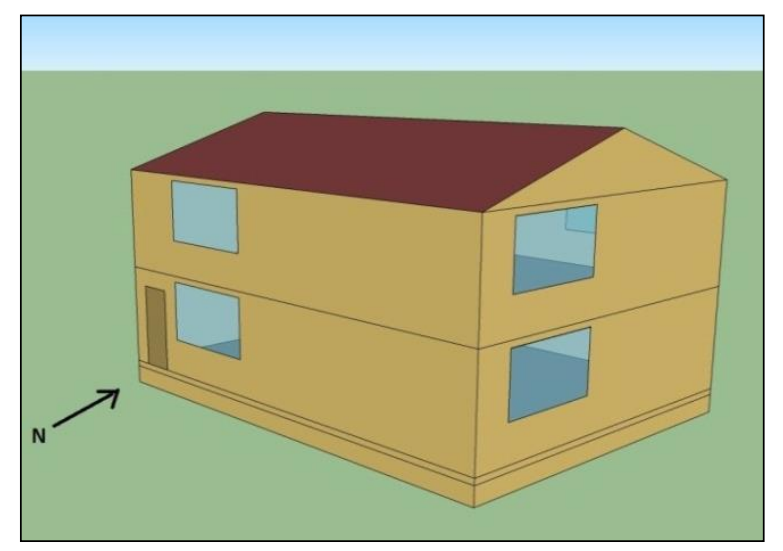

Figure 4.1. Image of the Single-Family Prototype

As depicted in Figure 4.2 and Figure 4.3, the multifamily prototype is configured as a three-story building with six dwelling units per floor, arranged in two rows with an open breezeway running through the middle. Each dwelling unit is modeled as a separate thermal zone. In addition to the resulting 18

\footnotetext{
${ }^{1}$ The term scorecard was coined by the ASHRAE project committee for Standard 90.1 for summaries of commercial building simulation inputs. These scorecards summarize only inputs, not outputs or scores or any kind.

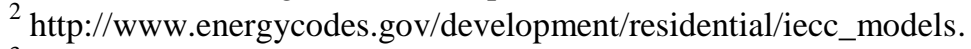

${ }^{3} \mathrm{http}: / /$ apps1.eere.energy.gov/buildings/energyplus/openstudio_suite.cfm.

${ }^{4}$ http://www.sketchup.com/.
} 
thermal zones (one for each dwelling unit), the model has an attic zone and, for models with a crawlspace or basement, a foundation zone.

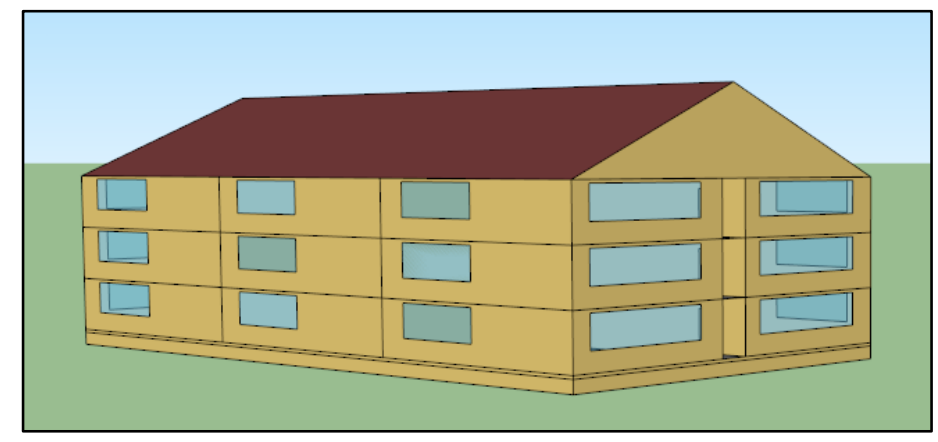

Figure 4.2. Image of the Multifamily Prototype

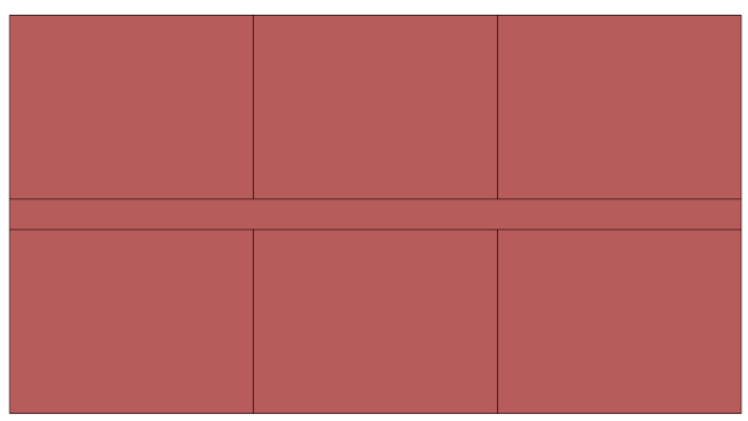

Figure 4.3. Plan View Showing Prototype Central Breezeway

\subsection{Building Envelope}

Both prototypes have gabled roofs with a 4:12 roof slope. Roof construction is assumed to be medium colored asphalt shingles with ceiling insulation placed entirely in the attic on the attic floor. For the multifamily prototype, ceiling insulation is assumed to be placed only on the ceilings at the top story exposed to unconditioned attic air. The attic is considered to be vented for both prototype buildings. The exterior walls are assumed to be wood-framed, with $2 \times 4$-in. studs spaced 16 in. on center or $2 \times 6$-in. studs spaced $24 \mathrm{in}$. on center depending on the thickness of wall insulation specified by the IECC. The floors are assumed to have wood joists spaced 24 in. on center. The ceiling, wall, and floor insulation levels are modeled according to the IECC code requirements for each code vintage.

Vertical fenestration for the single-family prototype is configured as a 15 percent window-to-floor ratio (WFR) distributed equally along all cardinal directions. The multifamily prototype is modeled with 23 percent window-to-wall ratio (WWR). However, the WWR calculation for the multi-family prototype does not include exterior walls facing the central breezeway. The WFR for the multifamily building prototype then is $10 \%$.Vertical fenestration is modeled using the U-factor and solar heat gain coefficient (SHGC) requirements specified in each version of the IECC. The models do not account for external shading geometry. No skylights are assumed for either prototype.

Four foundation types are simulated in this analysis: 1) slab-on-grade, 2) crawlspace vented to the outdoors with insulation assumed to be placed entirely in the floor joists, 3) heated basement with the 
below grade walls insulated to the requirements of the IECC, and 4) unheated basement with the insulation placed entirely in the floor joists.

\subsection{Internal Gains}

The IECC provides limited guidance on specifying internal gains for the standard reference and proposed designs (Table 404.5.2(1) in the 2006 IECC). The table specifies equation 4.1 below for use in calculating total daily internal heat gains based on the conditioned floor area and the number of bedrooms of the home. Table 4.1 below summarizes the corresponding internal gains applicable to the singlefamily and multifamily prototypes.

$$
\text { Internal Gains }=17,900+23.8 \times \mathrm{CFA}+4104 \times \mathrm{Nbr}(\mathrm{Btu} / \mathrm{day})
$$

where CFA is the conditioned floor area $\left(\mathrm{ft}^{2}\right)$ and Nbr is the number of bedrooms.

Table 4.1. Internal Gains for Single-Family and Multifamily Prototypes as Specified by the 2006 IECC

\begin{tabular}{lcccc}
\hline & $\mathrm{CFA}^{(\mathrm{a})}$ & $\mathrm{Nbr}^{(\mathrm{b})}$ & $\begin{array}{c}\text { Internal Gains } \\
\text { (Btu/Day) }\end{array}$ & $\begin{array}{c}\text { Internal Gains } \\
\text { (kBtu/year) }\end{array}$ \\
\hline Single-family & 2,400 & 3 & 87,332 & 31,876 \\
Multifamily & 1,200 & 2 & 54,668 & 19,954 \\
\hline
\end{tabular}

(a) $\mathrm{CFA}=$ Conditioned floor area.

(b) $\mathrm{Nbr}=$ Number of bedrooms.

To facilitate evaluation of lighting and appliance changes in EnergyPlus, these daily totals are split into various end uses. This breakdown of appliance loads and corresponding appliance-use schedules (Appendix A, Section A.4) is developed to match, as closely as possible, the Building America research benchmark (Hendron and Engebrecht 2009). The approximate difference between the internal gains specified by the IECC and the sum of lighting and appliances from Building America, an IECC adjustment factor, is added as an additional miscellaneous load component. A breakdown of annual energy consumption and associated internal loads for major appliances and other equipment for the single-family and multifamily prototypes are shown in Table 4.2 and Table 4.3 , respectively. 
Table 4.2. Breakdown of Internal Gains for the Single-Family Prototype

\begin{tabular}{|c|c|c|c|c|c|c|c|c|}
\hline \multirow[b]{2}{*}{ Appliance } & \multirow[b]{2}{*}{ Power } & \multirow{2}{*}{$\begin{array}{c}\text { Total } \\
\text { Electricity } \\
(\mathrm{kWh} / \mathrm{yr}) \\
\end{array}$} & \multicolumn{3}{|c|}{$\begin{array}{l}\text { Internal Heat Gain } \\
\text { (Fractions) }\end{array}$} & \multicolumn{3}{|c|}{$\begin{array}{c}\text { Internal Heat Gains } \\
(\mathrm{kWh} / \mathrm{yr})\end{array}$} \\
\hline & & & $\begin{array}{l}\text { Fraction } \\
\text { Sensible }\end{array}$ & $\begin{array}{l}\text { Fraction } \\
\text { Latent }\end{array}$ & $\begin{array}{l}\text { Fraction } \\
\text { Lost }\end{array}$ & $\begin{array}{l}2006 \\
\text { IECC }\end{array}$ & $\begin{array}{c}2009 \\
\text { IECC }\end{array}$ & $\begin{array}{c}2012 \\
\text { IECC }\end{array}$ \\
\hline Refrigerator & $91.09 \mathrm{~W}$ & 668.90 & 1.00 & 0.00 & 0.00 & 669 & 669 & 669 \\
\hline $\begin{array}{l}\text { Clothes } \\
\text { Washer }\end{array}$ & $29.6 \mathrm{~W}$ & 109.16 & 0.80 & 0.00 & 0.20 & 87 & 87 & 87 \\
\hline Clothes Dryer & $222.11 \mathrm{~W}$ & 868.15 & 0.15 & 0.05 & 0.80 & 174 & 174 & 174 \\
\hline Dishwasher & $68.33 \mathrm{~W}$ & 214.16 & 0.60 & 0.15 & 0.25 & 161 & 161 & 161 \\
\hline $\begin{array}{l}\text { Range } \\
\text { (electric/gas) }\end{array}$ & $248.97 \mathrm{~W}$ & 604.90 & 0.40 & 0.30 & 0.30 & 423 & 423 & 423 \\
\hline $\begin{array}{l}\text { Miscellaneous } \\
\text { Plug Loads }\end{array}$ & $\begin{array}{c}0.228 \\
\text { W/sq.ft }\end{array}$ & 3238.13 & 0.69 & 0.06 & 0.25 & 2429 & 2429 & 2429 \\
\hline $\begin{array}{l}\text { Miscellaneous } \\
\text { Electric Loads }\end{array}$ & $182.5 \mathrm{~W}$ & 1598.00 & 0.69 & 0.06 & 0.25 & 1199 & 1199 & 1199 \\
\hline $\begin{array}{l}\text { IECC } \\
\text { Adjustment } \\
\text { Factor }\end{array}$ & $0.0275 \mathrm{~W} / \mathrm{ft}^{2}$ & 390.56 & 0.69 & 0.06 & 0.25 & 293 & 293 & 293 \\
\hline Lighting & & & 1.00 & 0.00 & 0.00 & 1635 & 1345 & 1164 \\
\hline Occupants & \multicolumn{2}{|c|}{3 Occupants } & & & & 2123 & 2123 & 2123 \\
\hline Totals & & & & & $\begin{array}{l}\text { kWh/yr } \\
\text { kBtu/yr } \\
\text { Btu/day }\end{array}$ & $\begin{array}{c}9192 \\
31,362 \\
85,924\end{array}$ & $\begin{array}{c}8902 \\
30,373 \\
83,213 \\
\end{array}$ & $\begin{array}{c}8721 \\
29,755 \\
81,522\end{array}$ \\
\hline
\end{tabular}

Table 4.3. Breakdown of Internal Gains for the Multifamily Prototype (per dwelling unit)

\begin{tabular}{|c|c|c|c|c|c|c|c|c|}
\hline \multirow[b]{2}{*}{ Appliance } & \multirow[b]{2}{*}{ Power } & \multirow{2}{*}{$\begin{array}{c}\text { Total } \\
\text { Electricity } \\
(\mathrm{kWh} / \mathrm{yr})\end{array}$} & \multirow[b]{2}{*}{$\begin{array}{l}\text { Fraction } \\
\text { Sensible }\end{array}$} & \multirow[b]{2}{*}{$\begin{array}{c}\text { Fraction } \\
\text { Latent }\end{array}$} & \multirow[b]{2}{*}{$\begin{array}{c}\text { Fraction } \\
\text { lost }\end{array}$} & \multicolumn{3}{|c|}{$\begin{array}{c}\text { Internal Heat Gains } \\
(\mathrm{kWh} / \mathrm{yr})\end{array}$} \\
\hline & & & & & & $\begin{array}{l}2006 \\
\text { IECC }\end{array}$ & $\begin{array}{l}2009 \\
\text { IECC }\end{array}$ & $\begin{array}{l}2012 \\
\text { IECC }\end{array}$ \\
\hline Refrigerator & $91.09 \mathrm{~W}$ & 668.90 & 1.00 & 0.00 & 0 & 669 & 669 & 669 \\
\hline $\begin{array}{l}\text { Clothes } \\
\text { Washer }\end{array}$ & $29.6 \mathrm{~W}$ & 109.16 & 0.80 & 0.00 & 0.2 & 87 & 87 & 87 \\
\hline Clothes Dryer & $222.11 \mathrm{~W}$ & 868.15 & 0.15 & 0.05 & 0.8 & 174 & 174 & 174 \\
\hline Dishwasher & $68.33 \mathrm{~W}$ & 214.16 & 0.60 & 0.15 & 0.25 & 161 & 161 & 161 \\
\hline $\begin{array}{l}\text { Range } \\
\text { (electric) }\end{array}$ & $248.97 \mathrm{~W}$ & 604.00 & 0.40 & 0.30 & 0.3 & 423 & 423 & 423 \\
\hline $\begin{array}{l}\text { Miscellaneous } \\
\text { Plug Loads }\end{array}$ & $0.228 \mathrm{~W} / \mathrm{ft}^{2}$ & 1619.00 & 0.69 & 0.06 & 0.25 & 1214 & 1214 & 1214 \\
\hline $\begin{array}{l}\text { Miscellaneous } \\
\text { Electric Loads }\end{array}$ & $121.88 \mathrm{~W}$ & 1067.00 & 0.69 & 0.06 & 0.25 & 800 & 800 & 800 \\
\hline $\begin{array}{l}\text { IECC } \\
\text { Adjustment } \\
\text { Factor }\end{array}$ & $0.0275 \mathrm{~W} / \mathrm{ft}^{2}$ & 195.28 & 0.69 & 0.06 & 0.25 & 146 & 146 & 146 \\
\hline Lighting & & & 1.00 & 0.00 & 0 & 493 & 405 & 351 \\
\hline Occupants & 2 Occupants & & & & & 1416 & 1416 & 1416 \\
\hline Total & & & & & $\begin{array}{l}\text { kWh/yr } \\
\text { kBtu/yr } \\
\text { Btu/day }\end{array}$ & $\begin{array}{c}5583 \\
19,049 \\
52,189\end{array}$ & $\begin{array}{c}5495 \\
18,748 \\
51,364\end{array}$ & $\begin{array}{c}5440 \\
18,562 \\
50,855\end{array}$ \\
\hline
\end{tabular}




\subsection{Lighting}

Lighting is modeled as hardwired, plug-in, exterior, and garage lighting. The baseline 2006 IECC lighting characteristics and energy consumption are based on the Building America Simulation Protocols (Hendron and Engebrecht 2010). The corresponding lighting energy use for the 2006 IECC is calculated using Building America's equations shown in Error! Reference source not found. based on conditioned floor area (CFA).

Table 4.4. Baseline Lighting Energy Use for the 2006 IECC

\begin{tabular}{lll}
\hline \multicolumn{1}{c}{ Type } & & \multicolumn{1}{c}{ Energy Use } \\
\hline Interior Hardwired & $=.8 \times($ CFA $\times 0.542+334) \mathrm{kWh} / \mathrm{yr}$ \\
Interior Plug-in Lighting & $=$ & $0.2 \times($ CFA $\times 0.542+334) \mathrm{kWh} / \mathrm{yr}$ \\
Garage Lighting & $=$ & Garage Area $\times 0.08+8 \mathrm{kWh} / \mathrm{yr}$ \\
Exterior Lighting & $=$ & CFA $\times 0.145 \mathrm{kWh} / \mathrm{yr}$ \\
\hline
\end{tabular}

Building America assumes that 66 percent of all lamps are incandescent, 21 percent are compact fluorescent, and the remaining 13 percent are T-8 linear fluorescent in the baseline. The 2009 IECC and the 2012 IECC require 50 percent and 75 percent, respectively, of all lighting in permanently installed fixtures to be high efficacy. The lighting energy consumption for the 2009 and 2012 IECC is calculated using Building America's smart lamp replacement approach using fractions specified in Table 4.5 and equations $4.2,4.3$ and 4.4 .

Interior Hardwired lighting energy $=L h w x\{[($ Finc, $H W+0.34)+(F C F L, H W-0.21) \times 0.27+$

FLED, HW $\times 0.30+(F L F, H W-0.13) \times 0.17] \times S A F \times 0.9+0.1(\mathrm{kWh} / y \mathrm{r})$

Garage lighting energy $=$ LGAR $x\{[($ Finc, GAR + 0.34 $)+(F C F L, G A R-0.21) \times 0.27+F L E D, G A R x$ $0.30+(F L F, G A R-0.13) \times 0.17] \times 0.9+0.1(\mathrm{kWh} / \mathrm{yr})$

Exterior lighting energy $=$ LOUT $x\{[(F i n c, O U T+0.34)+(F C F L, O U T-0.21) \times 0.27+F L E D, O U T$ $x 0.30+(F L F, O U T-0.13) \times 0.17] \times 0.9+0.1(\mathrm{kWh} / \mathrm{yr})$

In those equations, LHW is the baseline hard-wired lighting energy, LGAR is the baseline garage lighting energy and LOUT is the baseline exterior lighting energy. Finc and FCFL are the fractions of fixture with incandescent lamps and fluorescent lamps, respectively.

Table 4.5. Lighting fixture type fractions for the 2006, 2009 and 2012 IECC

\begin{tabular}{lccc}
\hline & 2006 IECC & 2009 IECC & 2012 IECC \\
\hline Fraction Incandescent & 0.66 & 0.5 & 0.25 \\
Fraction CFL & 0.21 & 0.37 & 0.62 \\
Fraction Linear Fluorescent & 0.13 & 0.13 & 0.13 \\
\hline
\end{tabular}


Based on the Building America Simulation Protocols, when estimating the energy savings of the 2009 and 2012 IECC, a 10-percent take back is included in the form of an increase in operating hours to account for operational differences when incandescent lamps are replaced with energy-efficient lamps.

\subsection{Infiltration and Ventilation}

\subsubsection{Infiltration}

The infiltration rates are handled differently in each of the three versions of the IECC. The 2006 IECC does not require a blower door test nor does it include a detailed sealing inspection checklist. A benchmark construction infiltration rate of eight air changes at a $50 \mathrm{~Pa}$ pressure differential (ACH50) was established for the 2006 IECC based on the lower end of envelope leakage rates for typical new construction presented by Sherman (2007). ${ }^{1}$

The 2009 IECC provides two paths for compliance with its infiltration requirements. One is a standard blower door test with a seven-ACH50 limit and the other is inspection against a detailed air sealing checklist. This analysis assumes either path results in the same effective infiltration rate, so a leakage rate of seven-ACH50 is assumed for the 2009 IECC.

The 2012 IECC allows a maximum of five-ACH50 in Climate Zones 1 and 2, and three-ACH50 in Climate Zones 3 through 8, as determined by a standard blower door test. EnergyPlus contains multiple modules that can be used to model infiltration. The EnergyPlus ZoneInfiltration: EffectiveLeakageArea model, based on work done by Sherman and Grimsrud for smaller residential type of buildings ${ }^{2}$, was used in this analysis. This model uses the effective leakage area (ELA) derived from a standard blower door test to model infiltration loads on the zone.

The input to EnergyPlus is the ELA at a $4 \mathrm{~Pa}$ reference pressure differential. In contrast, a standard blower door test yields a leakage rate in air changes per hour at a 50-Pa pressure differential (ACH50). This value is converted to the EnergyPlus input using equations 4.5, 4.6, and 4.7 below. ${ }^{3}$

$$
\begin{gathered}
c f m 50=\frac{A C H 50 \times \text { Volume of the House }}{60} \\
C_{\text {ela }}=\frac{c f m 50}{50^{0.65}} \\
E L A=0.2833 * C_{\text {ela }} *\left(4^{0.65}\right)
\end{gathered}
$$

\footnotetext{
${ }^{1}$ M. Sherman 'Trends in US Ventilation' http://www.aivc.org/medias/pdf/07_USA.pdf

${ }^{2}$ EnergyPlus Input Output Reference http://apps1.eere.energy.gov/buildings/energyplus/pdfs/inputoutputreference.pdf ${ }^{3}$ P. Fairey 'EnergyGauge Envelope Leakage and Infiltration Conversions' http://www.energygauge.com/DOWNLOADS/EgUSA2802.pdf.
} 
In those equations, $c f m 50$ is the leakage flow-rate during the blower door test, $C_{\text {ela }}$ is the leakage co-efficient, and ELA is the equivalent leakage area that is the input parameter to EnergyPlus. Table 4.6 lists the specific ELA values used in this analysis as input to EnergyPlus.

Table 4.6. Air Changes at $50 \mathrm{~Pa}$ and Effective Leakage Area by IECC Version

\begin{tabular}{lccc}
\hline & & \multicolumn{2}{c}{ Effective Leakage Area (in. ${ }^{2}$ ) } \\
\cline { 3 - 4 } \multicolumn{1}{c}{ Code } & ACH50 & $\begin{array}{c}\text { Single-Family } \\
\text { Prototype }\end{array}$ & $\begin{array}{c}\text { Multifamily } \\
\text { Prototype }\end{array}$ \\
\hline 2006 IECC & 8 & 149.22 & 74.61 \\
2009 IECC & 7 & 130.57 & 65.28 \\
2012 IECC Climate Zones 1-2 & 5 & 93.26 & 46.63 \\
2012 IECC Climate Zones 3-8 & 3 & 55.96 & 27.98 \\
\hline
\end{tabular}

\subsubsection{Ventilation}

The 2012 IECC sets mechanical ventilation requirements for one and two family dwelling units and townhomes based on the 2012 International Residential Code (IRC) and those for low-rise multifamily buildings based on the 2012 International Mechanical Code (IMC). The maximum five or three-ACH50 leakage requirements in the 2012 IECC, coupled with mechanical ventilation requirements of the 2012 IRC and the 2012 IMC, mandates mechanical ventilation for all homes built under the 2012 IECC. $^{1}$ The IRC allows the ventilation system to be either continuously operating with a lower required outdoor air flow-rate or intermittently operating with a higher required outdoor air flow-rate. The IMC requires ventilation air to be supplied continuously when the building is occupied.

For the single-family prototype, the minimum outdoor air flow-rates are based on conditioned floor area and number of bedrooms and are listed in table M1507.3.3(1) of the 2012 IRC. For the low-rise multifamily prototype, the minimum outdoor air flow-rates are based on occupant density and are listed in table 403.3 of the 2012 IMC. For the purpose of this analysis, a whole-house continuously operating ventilation system is assumed. Outdoor air flow rates required by the 2012 IRC and the 2012 IMC used in the simulations are summarized in Table 4.7.

Table 4.7. Outdoor Air Flow Rates Used in Simulations

\begin{tabular}{lc}
\hline \multicolumn{1}{c}{ Prototype } & $\begin{array}{c}\text { Outdoor Air Flow Rate used in Simulation } \\
\left(\mathrm{ft}^{3} / \mathrm{min}\right)\end{array}$ \\
\hline Single-Family & 60 \\
Multifamily & 45 \\
\hline
\end{tabular}

\footnotetext{
${ }^{1}$ Section R303.4 of the 2012 IRC actually requires ventilation only when envelope leakage is less than five ACH50. Ventilation is not required for a home with a leakage rate of exactly five ACH50. This analysis assumes that such homes are rare and that all 2012 IECC-compliant homes will fall under the ventilation requirement.
} 
There is growing consensus among building scientists that a ventilation system is necessary in new residential buildings regardless of the vintage of the building energy code in order to ensure a reliable supply of fresh air to maintain indoor air quality. Specific comments from the ASHRAE Standard 90.2 committee for analyses conducted in support of the development of standard 90.2 suggested assuming the same mechanical ventilation rates for the 2006 IECC, even though the 2006 IECC does not specifically require mechanical ventilation. ${ }^{1}$ Therefore, for this analysis, the same mechanical ventilation system and outdoor air flow-rates are assumed in all analyzed code versions.

Ventilation is modeled using the EnergyPlus Zone: Ventilation model using the outdoor flow rates from Table 4.7 and a continuous ventilation fan operation schedule.

\subsection{Heating, Ventilation, and Air-Conditioning Systems}

All homes are assumed to have a central forced-air distribution system served by either a heat pump or an electric air-conditioner coupled with an electric, natural-gas, or oil furnace.

\subsubsection{Operating Conditions}

Thermostat set-points for all models are based on the 2012 IECC performance path specifications (Table R405.5.2(1) in the 2012 IECC). The relevant set-points, which apply to both the standard reference design and proposed design, are a heating set-point of $72^{\circ} \mathrm{F}$ without a setback period and a cooling set-point of $75^{\circ} \mathrm{F}$ without a setup period.

\subsubsection{HVAC System Efficiency}

None of the IECC versions specifies efficiency requirements for heating, ventilation, and air conditioning (HVAC) systems. A federal equipment standards rulemaking process governs minimum heating and cooling equipment efficiencies at the manufacturing level. ${ }^{2}$ Federal minimum baseline efficiencies in effect as of May 2012 for residential central air conditioners, heat pumps and furnaces are assumed to apply for the purpose of this analysis $\left(10\right.$ CFR $\left.430^{3}\right)$. Table 4.8 shows the heating and cooling equipment efficiencies used in the analysis.

Table 4.8. Heating and Cooling Equipment Efficiencies used in this Analysis.

\begin{tabular}{|c|c|c|c|c|}
\hline \multicolumn{5}{|c|}{ Equipment Efficiencies } \\
\hline $\begin{array}{c}\text { Air Conditioner } \\
\text { SEER }^{(a)}\end{array}$ & $\begin{array}{l}\text { Heat Pump } \\
\text { SEER }\end{array}$ & Gas Furnace AFUE $^{(b)}$ & $\begin{array}{c}\text { Oil Furnace } \\
\text { AFUE }\end{array}$ & Heat Pump HSPF ${ }^{(c)}$ \\
\hline 13 & 13 & $78 \%$ & $78 \%$ & 7.7 \\
\hline $\begin{array}{l}\text { (a) SEER = Seasona } \\
\text { (b) } \text { AFUE = Annual } \\
\text { (c) HSPF = Heating }\end{array}$ & $\begin{array}{l}\text { Efficiency } \\
\text { lization Effic } \\
\text { I Performano }\end{array}$ & & & \\
\hline
\end{tabular}

\footnotetext{
${ }^{1}$ These comments were received during the web meeting held on March 22, 2012, for the development of the ASHRAE 90.2-2014 standard.

${ }^{2}$ Per the requirements of the National Appliance Energy Conservation Act of 1987 (NAECA), as amended.

${ }^{3}$ http://www.gpo.gov/fdsys/pkg/CFR-2011-title10-vol3/pdf/CFR-2011-title10-vol3-sec430-32.pdf.
} 


\subsubsection{Air Distribution System and Duct Leakage Rates}

All models in the analysis are assumed to have a centralized supply and return duct system. The air distribution system is modeled using the EnergyPlus Airflownetwork. The model has capabilities for modeling wind and pressure-driven air flows through the building shell as well as detailed thermal gains and losses and leakages through the air-distribution system.

The 2006 IECC does not specify a maximum allowable duct leakage rate. Research done by Building America indicates that typical new homes with ducts in attics or crawlspaces lose about 25 to 40 percent of the heating or cooling energy that passes through the ducts. In EnergyPlus, duct leakage is defined as a ratio of the total supply air flow-rate. A conservative baseline duct leakage rate of 15 percent on the supply side and 15 percent on the return side for the 2006 IECC is assumed in this analysis, based on research done by Building America. ${ }^{1}$ The ducts are assumed to be located in the unconditioned attic space and all the leakage is assumed to take place in this zone. The 2009 and 2012 IECC specify limits on duct leakage in terms of cubic feet per minute (CFM) per $100 \mathrm{ft}^{2}$ conditioned floor area at a 25-Pa pressure differential. This value is converted into a ratio of duct leakage CFM to the total supply CFM for input to EnergyPlus. The leakage is assumed to be equally distributed between the supply and return air sides. These leakage inputs are summarized in

Table 4.9.

Table 4.9. Duct Leakage Rates

\begin{tabular}{ccc}
\hline & $\begin{array}{c}\text { Maximum Allowed Duct Leakage Rate } \\
\left(\mathrm{CFM} / 100 \mathrm{ft}^{2} \text { conditioned floor area at a 25-Pa }\right. \\
\text { pressure differential) }\end{array}$ & $\begin{array}{c}\text { Duct Leakage Ratio (percent of } \\
\text { total supply CFM) }\end{array}$ \\
\hline Energy Code & Not specified & $15 \%$ supply and 15\% return \\
2006 IECC & 8 & $10 \%$ supply and 10\% return \\
2009 IECC & 4 & $4 \%$ supply and 4\% return \\
\hline
\end{tabular}

Some modules within the EnergyPlus Airflownetwork were still under development at the time of this analysis, thus requiring a workaround to complete the simulations. The impacts of duct leakage on heating and cooling energy were simulated separately from other building elements and added to the energy results through post-processing. A separate suit of 11,424 models was created with the ductleakage rates set to the 2006, 2009, and 2012 IECC levels, respectively, and the rest of the requirements were maintained at the 2006 IECC level. This approach allowed the impact of duct leakage on heating and cooling energy to be isolated and captured. This impact was then added to the energy use results from the 2009 and 2012 IECC models through post-processing.

\footnotetext{
${ }^{1}$ Building America "Better Duct Systems for Home Heating and Cooling" http://www.nrel.gov/docs/fy05osti/30506.pdf.
} 


\subsection{Domestic Hot Water System}

The domestic hot water system in all models is assumed to be a storage type water heater. For models that represent homes with fuel-fired furnaces as space-heating equipment, water heaters are modeled as gas-fired storage water heaters. For models that represent homes with electricity as the space heating fuel (electric furnace and heat pump), water heaters are assumed to be electric storage tank type water heaters.

The size of the storage tank is assumed to be 40 gal for gas-fired water heaters and 52 gal for electric water heaters. For the purpose of modeling, domestic hot water use is split into various end-uses such as baths, sinks, clothes washer, dishwasher, and showers using peak flow rates and schedules from the Building America House Simulation Protocols.

Commercially available residential size water heaters are rated in terms of an Energy Factor (EF). A federal rulemaking process determines minimum allowable EF values that depend on the equipment type and capacity (storage volume). ${ }^{1}$ This analysis assumes EF values based on the federal rule in effect as of May 2012.

Table 4.10 summarizes the EF for gas-fired and electric water heaters used in this analysis.

Table 4.10. Water Heater Energy Factor used in the Analysis

\begin{tabular}{cc}
\hline Water Heater Type & Energy Factor \\
\hline Gas fired storage type & 0.594 \\
Electric storage type & 0.917 \\
\hline
\end{tabular}

For modeling purposes, the EF has to be split into a burner thermal efficiency and standby losses. These calculations are carried out using equations from the Water Heater Analysis Model (WHAM) (Lutz et al. 1998). Table 4.11 summarizes thermal efficiency and shell losses for each case.

Table 4.11. Standby Losses and Burner Thermal Efficiencies for Water Heaters

\begin{tabular}{ccc}
\hline Water Heater Type & Shell Losses-UA $\left(\mathrm{Btu} / \mathrm{hr}-{ }^{\circ} \mathrm{F}\right)$ & Burner Thermal Efficiency \\
\hline Gas fired storage type & 10.84 & $80 \%$ \\
Electric storage type & 2.52 & $100 \%$ \\
\hline
\end{tabular}

The 2012 IECC specifies requirements for insulating hot water pipes for service water heating (faucets, showers, etc.). This insulation requirement did not exist in the 2006 or 2009 IECC. The savings from this requirement are variable, because they depend on system design and occupant behavior, and are not easy to capture with an energy model. Klein estimates the 2012 IECC requirements save from 10.2 to 27.4 percent of the overall hot water energy consumption for a typical household (Klein 2012). This analysis uses a conservative estimate of 10 percent hot water energy savings. These savings are applied to the simulated hot water energy consumption through post-processing.

\footnotetext{
${ }^{1} \mathrm{http} / / /$ www1.eere.energy.gov/buildings/appliance_standards/residential/pdfs/htgp_finalrule_fedreg.pdf.
} 


\subsection{Energy Costs}

\subsection{Energy Use}

EnergyPlus provides detailed end-use energy consumption estimates, potentially at high time resolution (monthly, hourly, or even sub-hourly). For this analysis, only annual end-use energy consumption, taken from the EnergyPlus 'table.csv' output report, is used. As specified in the costeffectiveness methodology, energy savings for cost-effectiveness considerations are limited to heating, cooling, domestic hot water heating, and lighting to match the scope of the IECC.

\subsection{Fuel Prices}

Fuel prices and anticipated price escalation rates are needed to determine the energy cost savings from improved energy efficiency. This analysis uses the most recently available state-specific residential fuel prices from DOE's Energy Information Administration. ${ }^{1,2} 3$ Electricity prices vary by the heating or cooling season. For air conditioning, electricity prices from the summer are used, and for electric space heating, winter electricity prices are used. Fuel price escalation rates are obtained from the most recent Annual Energy Outlook to account for projected changes in energy prices. This analysis assumes an average fuel escalation rate of $2.2 \%$. Table 5.1 lists the state specific prices used for electricity, gas and oil.

Table 5.1. Fuel Prices by State

\begin{tabular}{lcccc}
\hline \multicolumn{1}{c}{ State } & $\begin{array}{c}\text { Electricity }(\$ / \mathrm{kWh}) \\
(\text { Heating })\end{array}$ & $\begin{array}{c}\text { Electricity }(\$ / \mathrm{kWh}) \\
(\text { Cooling })\end{array}$ & $\begin{array}{c}\text { Gas } \\
(\$ / \text { Therm })\end{array}$ & $\begin{array}{c}\text { Oil } \\
(\$ \mathrm{MBtu})\end{array}$ \\
\hline Alabama & 0.106 & 0.109 & 1.329 & 23.7 \\
Alaska & 0.166 & 0.171 & 0.839 & 23.7 \\
Arizona & 0.099 & 0.117 & 1.306 & 23.7 \\
Arkansas & 0.08 & 0.092 & 0.924 & 23.7 \\
California & 0.149 & 0.156 & 0.943 & 23.7 \\
Colorado & 0.104 & 0.118 & 0.714 & 23.7 \\
Connecticut & 0.181 & 0.192 & 1.244 & 23.86 \\
Delaware & 0.133 & 0.142 & 1.365 & 23.7 \\
District of Columbia & 0.135 & 0.143 & 1.202 & 23.7 \\
Florida & 0.117 & 0.117 & 1.532 & 23.7 \\
Georgia & 0.098 & 0.109 & 1.249 & 23.7 \\
Hawaii & 0.301 & 0.284 & 4.72 & 23.7 \\
Idaho & 0.078 & 0.084 & 0.869 & 23.7 \\
Illinois & 0.108 & 0.122 & 0.717 & 23.7
\end{tabular}

\footnotetext{
${ }^{1}$ U.S. Department of Energy (DOE). 2012a. Electric Power Monthly. DOE/EIA-0226. Washington, D.C. http://www.eia.doe.gov/cneaf/electricity/epm/table5_6_a.html

2 U.S. Department of Energy (DOE). 2012b. Natural Gas Monthly. DOE/EIA-0130. Washington, D.C. http://www.eia.gov/oil_gas/natural_gas/data_publications/natural_gas_monthly/ngm.html

$3{ }^{3}$ U.S. Department of Energy (DOE). 2012c. Petroleum Marketing Monthly. DOE/EIA-0380. Washington, D.C. http://www.eia.gov/petroleum/marketing/monthly/
} 
Table 5.1. (contd)

\begin{tabular}{|c|c|c|c|c|}
\hline State & $\begin{array}{c}\text { Electricity }(\$ / \mathrm{kWh}) \\
(\text { Heating) }\end{array}$ & $\begin{array}{c}\text { Electricity }(\$ / \mathrm{kWh}) \\
(\text { Cooling })\end{array}$ & $\begin{array}{c}\text { Gas } \\
(\$ / \text { Therm) }\end{array}$ & $\begin{array}{c}\text { Oil } \\
(\$ / \mathrm{MBtu})\end{array}$ \\
\hline Indiana & 0.094 & 0.093 & 0.804 & 23.7 \\
\hline Iowa & 0.096 & 0.11 & 0.802 & 23.7 \\
\hline Kansas & 0.095 & 0.105 & 0.815 & 23.7 \\
\hline Kentucky & 0.086 & 0.087 & 0.858 & 23.7 \\
\hline Louisiana & 0.081 & 0.092 & 0.933 & 23.7 \\
\hline Maine & 0.158 & 0.155 & 1.353 & 22.21 \\
\hline Maryland & 0.134 & 0.151 & 1.039 & 23.7 \\
\hline Massachusetts & 0.148 & 0.149 & 1.405 & 24.06 \\
\hline Michigan & 0.123 & 0.131 & 0.971 & 23.7 \\
\hline Minnesota & 0.103 & 0.108 & 0.833 & 23.7 \\
\hline Mississippi & 0.098 & 0.102 & 0.848 & 23.7 \\
\hline Missouri & 0.082 & 0.103 & 0.973 & 23.7 \\
\hline Montana & 0.091 & 0.096 & 0.795 & 23.7 \\
\hline Nebraska & 0.079 & 0.102 & 0.762 & 23.7 \\
\hline Nevada & 0.118 & 0.122 & 0.977 & 23.7 \\
\hline New Hampshire & 0.164 & 0.163 & 1.299 & 22.47 \\
\hline New Jersey & 0.163 & 0.172 & 1.162 & 23.7 \\
\hline New Mexico & 0.099 & 0.116 & 0.791 & 23.7 \\
\hline New York & 0.175 & 0.192 & 1.177 & 23.87 \\
\hline North Carolina & 0.097 & 0.103 & 0.992 & 23.7 \\
\hline North Dakota & 0.073 & 0.094 & 0.685 & 23.7 \\
\hline Ohio & 0.104 & 0.118 & 0.93 & 23.7 \\
\hline Oklahoma & 0.082 & 0.095 & 0.724 & 23.7 \\
\hline Oregon & 0.091 & 0.092 & 1.174 & 23.7 \\
\hline Pennsylvania & 0.125 & 0.133 & 1.101 & 23.41 \\
\hline Rhode Island & 0.158 & 0.162 & 1.369 & 24.47 \\
\hline South Carolina & 0.107 & 0.106 & 1.018 & 23.7 \\
\hline South Dakota & 0.083 & 0.097 & 0.749 & 23.7 \\
\hline Tennessee & 0.095 & 0.095 & 0.862 & 23.7 \\
\hline Texas & 0.11 & 0.12 & 0.814 & 23.7 \\
\hline Utah & 0.083 & 0.094 & 0.843 & 23.7 \\
\hline Vermont & 0.158 & 0.155 & 1.433 & 23.13 \\
\hline Virginia & 0.098 & 0.108 & 1.077 & 23.7 \\
\hline Washington & 0.08 & 0.083 & 1.142 & 23.7 \\
\hline West Virginia & 0.088 & 0.089 & 0.988 & 23.7 \\
\hline Wisconsin & 0.124 & 0.126 & 0.918 & 23.7 \\
\hline Wyoming & 0.084 & 0.093 & 0.747 & 23.7 \\
\hline
\end{tabular}




\subsection{Construction Cost Calculation}

\subsection{Requirements by Climate Zone for Each Code Level}

The 2009 and 2012 IECC have more stringent energy efficiency requirements than the 2006 IECC. Some of the requirements are constant across climate zones while some requirements vary. Table 6.1 summarizes the prescriptive requirements of the three versions of IECC analyzed in this study that vary by climate zone. Table 6.2 summarizes mandatory and prescriptive requirements that do not vary by climate zone.

\subsection{Incremental Cost Calculation}

The analysis compares the energy savings and cost effectiveness of the 2009 and 2012 IECC compared to the 2006 IECC. Cost effectiveness is calculated using incremental first cost and energy savings resulting from improvements in the code. The following sections detail incremental cost calculation for each component.

There are several existing studies on construction cost impacts for improved energy efficiency in residential new construction. Cost data sources consulted include but are not limited to:

- Construction cost data collected by Faithful+Gould in 2011 and 2012 under contract with PNNL ${ }^{1}$

- RS Means Residential Cost Data (RS Means 2011)

- ASHRAE Research Project 1481 (NAHB 2009).

All the costs used in this analysis are documented in the BC3 database. ${ }^{2}$

\subsubsection{Duct Testing and Improved Duct Sealing}

Section 403.2.2 of the 2009 and 2012 IECC require air distribution systems, where any of the ducts pass outside of the conditioned space (in attics, garages, etc.), to be pressure tested against specified maximum leakage rates. Testing is not required if all ducts and air handlers are inside the building envelope (for example in heated basements). All three versions of the IECC require all ducts to be sealed even if they are located inside the envelope. However, the 2006 IECC does not require ducts to be pressure tested for leakage. Thus, for the 2009 and 2012 IECC, there is an additional incremental cost for the pressure test (e.g., a duct blaster® test) and for additional sealing to achieve the required leakage rates.

\footnotetext{
${ }^{1}$ Faithful+Gould "Prototype Estimate and Cost Data" http://bc3.pnnl.gov/wiki/images/f/fa/Residential_Report.pdf.

${ }^{2}$ http://bc3.pnnl.gov/wiki/index.php/Main_Page
} 
Table 6.1. Prescriptive Code Requirements that Vary by Climate Zone

\begin{tabular}{|c|c|c|c|c|c|c|c|c|c|c|c|c|}
\hline \multirow{3}{*}{$\begin{array}{l}\text { Climate } \\
\text { Zone }\end{array}$} & \multirow[b]{3}{*}{ IECC } & \multicolumn{11}{|c|}{ Components } \\
\hline & & \multirow[b]{2}{*}{$\begin{array}{l}\text { Ceiling } \\
\text { (R-value) }\end{array}$} & \multirow{2}{*}{$\begin{array}{l}\text { Skylight } \\
\text { (U-factor) }\end{array}$} & \multicolumn{2}{|c|}{$\begin{array}{l}\text { Fenestration (Windows } \\
\text { and Doors) }\end{array}$} & \multirow{2}{*}{$\begin{array}{c}\text { Wood } \\
\text { Frame } \\
\text { Wall } \\
\text { (R-value) }\end{array}$} & \multirow{2}{*}{$\begin{array}{c}\text { Mass } \\
\text { Wall }^{(a)} \\
\text { (R-value) }\end{array}$} & \multirow{2}{*}{$\begin{array}{c}\text { Floor } \\
\text { (R-value) }\end{array}$} & \multirow{2}{*}{$\begin{array}{c}\text { Basement } \\
\text { Wall }^{(b)} \\
\text { (R-value) }\end{array}$} & \multirow{2}{*}{$\begin{array}{c}\text { Tested Max } \\
\text { Air Leakage } \\
\text { Rate } \\
\text { (air changes } \\
\text { per hour) }\end{array}$} & \multirow{2}{*}{$\begin{array}{c}\text { Slab }^{(\mathrm{c})} \\
\text { (R-value } \\
\text { and depth) }\end{array}$} & \multirow{2}{*}{$\begin{array}{c}\text { Crawl } \\
\text { Space }^{(b)} \\
\text { (R-value) }\end{array}$} \\
\hline & & & & U-factor & SHGC & & & & & & & \\
\hline \multirow{3}{*}{1} & 2006 & & & & 0.4 & & & & & NR & & \\
\hline & 2009 & 30 & 0.75 & NR & 0.3 & 13 & $3 / 4$ & 13 & NR & NR & NR & NR \\
\hline & 2012 & & & & 0.25 & & & & & 5 & & \\
\hline \multirow{3}{*}{2} & 2006 & 30 & 0.75 & 0.75 & 0.4 & & & & & NR & & \\
\hline & 2009 & 30 & 0.75 & 0.65 & 0.3 & 13 & $4 / 6$ & 13 & NR & NR & NR & NR \\
\hline & 2012 & 38 & 0.65 & 0.4 & 0.25 & & & & & 5 & & \\
\hline \multirow{3}{*}{3} & 2006 & 30 & 0.65 & 0.65 & 0.4 & 13 & $5 / 8$ & & 0 & NR & & \\
\hline & 2009 & 30 & 0.65 & 0.5 & 0.3 & 13 & $5 / 8$ & 19 & $5 / 13^{(\mathrm{d})}$ & NR & NR & $5 / 13$ \\
\hline & 2012 & 38 & 0.55 & 0.35 & 0.25 & 20 & $8 / 13$ & & $5 / 13^{(\mathrm{d})}$ & 3 & & \\
\hline \multirow{3}{*}{4} & 2006 & 38 & 0.6 & 0.4 & \multirow{2}{*}{ NR } & 13 & $5 / 13$ & & $10 / 13$ & NR & & $10 / 13$ \\
\hline & 2009 & 38 & 0.6 & 0.35 & & 13 & $5 / 10$ & 19 & $10 / 13$ & NR & $10,2 \mathrm{ft}$ & $10 / 13$ \\
\hline & 2012 & 49 & 0.55 & 0.35 & 0.4 & 20 & $8 / 13$ & & $10 / 13$ & 3 & & $10 / 13$ \\
\hline \multirow{3}{*}{5} & 2006 & 38 & 0.6 & 0.35 & & 19 & $13 / 19$ & & $10 / 13$ & NR & & $10 / 13$ \\
\hline & 2009 & 38 & 0.6 & 0.35 & NR & 20 & $13 / 17$ & 30 & $10 / 13$ & NR & $10,2 \mathrm{ft}$ & $10 / 13$ \\
\hline & 2012 & 49 & 0.55 & 0.32 & & 20 & $15 / 19$ & & $15 / 19$ & 3 & & $15 / 19$ \\
\hline \multirow{3}{*}{6} & 2006 & & 0.6 & 0.35 & & 19 & $10 / 13$ & & $10 / 13$ & NR & & $10 / 13$ \\
\hline & 2009 & 49 & 0.6 & 0.35 & NR & 20 & $15 / 19$ & 30 & $15 / 19$ & NR & $10,4 \mathrm{ft}$ & $10 / 13$ \\
\hline & 2012 & & 0.55 & 0.32 & & $20+5$ & $15 / 19$ & & $15 / 19$ & 3 & & $15 / 19$ \\
\hline \multirow{3}{*}{7 and 8} & 2006 & & 0.6 & 0.35 & & 21 & & 30 & $10 / 13$ & NR & & $10 / 13$ \\
\hline & 2009 & 49 & 0.6 & 0.35 & NR & 21 & $19 / 21$ & 38 & $15 / 19$ & NR & $10,4 \mathrm{ft}$ & $10 / 13$ \\
\hline & 2012 & & 0.55 & 0.32 & & $20+5$ & & 38 & $15 / 19$ & 3 & & $15 / 19$ \\
\hline \multicolumn{13}{|c|}{ (a) The second number applies when more than half the insulation is on the interior side of the high mass material in the wall. } \\
\hline \multicolumn{13}{|c|}{$\begin{array}{l}\text { furred-out wall built against the foundation wall). Only one of these two has to be met. } \\
\text { (c) The first number is R-value. The second value refers to the vertical depth of the insulation around the perimeter. } \\
\text { (d) Basement wall insulation is not required in the warm-humid region of Zone } 3 \text { in the southeastern United States. } \\
\text { IECC = International Energy Conservation Code. } \\
\text { NR } \quad \text { = Not required. } \\
\text { SHGC = Solar heat gain coefficient. }\end{array}$} \\
\hline
\end{tabular}


Table 6.2. Major Code Requirements that do not vary by Climate Zone

\begin{tabular}{|c|c|c|c|}
\hline Requirement & 2006 IECC & 2009 IECC & 2012 IECC \\
\hline Building envelope sealing & $\begin{array}{l}\text { Caulked and sealed } \\
\text { verified by visual } \\
\text { inspection }\end{array}$ & $\begin{array}{l}\text { Caulked and sealed } \\
\text { verified by visual } \\
\text { inspection against a } \\
\text { more detailed } \\
\text { checklist }\end{array}$ & $\begin{array}{l}\text { Caulked and sealed verified by } \\
\text { visual inspection and a pressure } \\
\text { test against a stringent leakage } \\
\text { requirement }\end{array}$ \\
\hline Ducts and air handlers & $\begin{array}{l}\text { Sealed verified by } \\
\text { visual inspection }\end{array}$ & $\begin{array}{l}\text { Sealed, verified by } \\
\text { visual inspection, } \\
\text { and pressure tested } \\
\text { or all ducts must be } \\
\text { inside building } \\
\text { envelope }\end{array}$ & $\begin{array}{l}\text { Sealed, verified by visual } \\
\text { inspection, and pressure tested } \\
\text { against a more stringent leakage } \\
\text { requirement or all ducts must be } \\
\text { inside building envelope }\end{array}$ \\
\hline Supply ducts in attics & $\mathrm{R}-8$ & $\mathrm{R}-8$ & $\mathrm{R}-8$ \\
\hline $\begin{array}{l}\text { Return ducts in attics and all } \\
\text { ducts in crawlspaces, unheated } \\
\text { basements, garages, or } \\
\text { otherwise outside the building } \\
\text { envelope }\end{array}$ & $\mathrm{R}-8$ & R-6 & R-6 \\
\hline $\begin{array}{l}\text { Insulation on hot water pipes } \\
\text { for service water heating } \\
\text { systems }\end{array}$ & None & None & $\begin{array}{l}\text { R-3 except where pipe run length } \\
\text { is below a diameter-dependent } \\
\text { threshold }\end{array}$ \\
\hline $\begin{array}{l}\text { Insulation on hot water pipes } \\
\text { for hydronic (boiler) space } \\
\text { heating systems }\end{array}$ & $\mathrm{R}-3$ & $\mathrm{R}-3$ & $\mathrm{R}-3$ \\
\hline $\begin{array}{l}\text { High-efficacy lamps (percent of } \\
\text { lighting in the home) }\end{array}$ & None & $50 \%$ of lamps & $75 \%$ of lamps or $75 \%$ of fixtures \\
\hline $\begin{array}{l}\text { Certificate of insulation levels } \\
\text { and other energy efficiency } \\
\text { measures }\end{array}$ & Yes & Yes & Yes \\
\hline
\end{tabular}

Faithful+Gould reports a cost of $\$ 135$ for duct testing when done as part of the construction process rather than as a one-off site visit test. Hammon and Modera (2009) estimate a cost of $\$ 131$ to $\$ 163$ for testing, and suggest costs will be even lower in a mature market. The Journal of Light Construction quotes a cost of \$220 for testing (Uniacke 2003). An Appalachian State University study (Appalachian State University 2010) reports a cost of $\$ 175$ to $\$ 250$. It is important to note that the IECC allows the ducts to be tested by the HVAC contractor immediately after the ducts are installed. This should help keep both costs and construction timeline impacts to a minimum. A cost of $\$ 135$ per duct blaster test is assumed in this analysis. Each dwelling unit within the multifamily building is assumed to have its own duct distribution system and thus a separate test would be conducted for each.

The second cost is the cost associated with further improvements in duct sealing to ensure the duct complies with the air leakage limits set in the code of interest. This is expected to be mostly labor costs. Hammon and Modera (1999) estimate a cost of \$214 for materials and labor for improved duct sealing. The developers of Energy Star Home requirements estimated a cost of $\$ 0.10 / \mathrm{ft}^{2}$ of conditioned home floor area for improved duct sealing (EPA 2011). This results in a cost of $\$ 240$ for a $2400-\mathrm{ft}^{2}$ home and $\$ 120$ for a $1200-\mathrm{ft}^{2} \mathrm{dwelling}$ unit. A conservative estimate of $\$ 240$ per home and $\$ 120$ per dwelling unit is used in this analysis for single-family and multifamily buildings, respectively. 
The total cost for duct testing and improved duct sealing for the 2009 IECC thus works out to be $\$ 375$ for a typical new single-family home and $\$ 255$ for a typical dwelling unit in a multifamily building, relative to the 2006 IECC. The 2012 IECC has lower allowable duct leakage rates compared to the 2009 IECC. An additional \$100 is estimated for further improvements in duct sealing for the 2012 IECC, increasing the total sealing and testing cost to $\$ 475$ for single-family homes and $\$ 355$ for each dwelling unit within a multifamily building relative to the 2006 IECC.

\subsubsection{Building Envelope Testing and Improved Envelope Sealing}

Section 402.4.2 of the 2009 IECC provides two options for demonstrating envelope air tightness: a pressure test to verify that the leakage rate is below the specified leakage rate or a visual inspection option accompanied with a checklist (Table 402.4.2). This analysis assumes that either option would result in the same envelope leakage rate.

Section R402.4.1.2 of the 2012 IECC requires the building envelope to be pressure tested to verify that the leakage rate is at or below specified maximum leakage rates. Faithful+Gould reports a cost of $\$ 135$ for envelope testing when done as part of the construction process rather than as a one-off site visit test. Similar to the duct blaster test for the multifamily prototype building, it is assumed that each dwelling unit will be tested for envelope leakage separately, thus costing \$135 per dwelling unit.

The developers of Energy Star Home Requirements estimated a cost of $\$ 0.25 / \mathrm{ft}^{2}$ of home floor area for improved envelope sealing (EPA 2011). This is a cost of $\$ 600$ for a $2400-\mathrm{ft}^{2}$ home and a cost of $\$ 300$ for a $1200-\mathrm{ft}^{2}$ dwelling unit. This analysis assumes this to be the total cost of improved envelope sealing for 2012 IECC over 2006 IECC. The cost for improved envelope sealing for the 2009 IECC is calculated proportionally as $\$ 0.05 / \mathrm{ft}^{2}$ of home floor area. Thus, the cost of improved envelope sealing is $\$ 120$ for the single-family prototype building and $\$ 60$ for each dwelling unit in the multifamily prototype building for the 2009 IECC over the 2006 IECC.

The cost of pressure testing the envelope and improved sealing is assumed to be $\$ 735$ for the singlefamily prototype and $\$ 435$ for each dwelling unit in the multifamily prototype building for the 2012 IECC over the 2006 IECC.

\subsubsection{Window Improvements (U-Factor and Solar Heat Gain Reduction)}

The thermal performance of windows is described using two parameters: the effective heat transfer co-efficient (U-factor) and the Solar Heat Gain Coefficient (SHGC). The 2009 and 2012 IECC require varying degrees of improvement of these two parameters over the 2006 IECC across various climate zones. These prescriptive requirements are summarized along with other envelope requirements in Table 6.1. Table 6.3 also presents these requirements for windows in the three versions of the IECC. The single-family and multifamily building prototype models do not have skylights; hence, the requirements for skylights are not analyzed in this study.

It is challenging to assign a cost for the improvement in window U-factor and SHGC because these two parameters are properties of the window assembly as a whole and can be achieved with a wide variety of window products with a similarly wide range of costs. Although a variety of window products and technologies can be used to comply with the requirements of the 2006, 2009 and 2012 IECC, it is 
expected that the most common method will have the same basic features and will be used in all climate zones. The common use of a low-emissivity (i.e., low-E) coating has the effect of lowering both the $\mathrm{U}$-factor and the SHGC. Thus, the same double-paned window with a low-E coating and a non-aluminum frame (typically wood or vinyl) often will meet both the low U-factor requirements in northern climate zones and the low SHGC requirements in southern climate zones.

Table 6.3. U-Factor and SHGC Requirements for Windows in the 2006, 2009, and 2012 IECC

\begin{tabular}{|c|c|c|c|c|}
\hline \multirow[b]{2}{*}{ Climate Zone } & \multirow[b]{2}{*}{ IECC } & \multirow{2}{*}{$\begin{array}{l}\text { Skylight } \\
\text { (U-Factor) }\end{array}$} & \multicolumn{2}{|c|}{ Fenestration (Windows and Doors) } \\
\hline & & & U-Factor & SHGC \\
\hline \multirow{3}{*}{1} & 2006 & & & 0.4 \\
\hline & 2009 & 0.75 & NR & 0.3 \\
\hline & 2012 & & & 0.25 \\
\hline \multirow{3}{*}{2} & 2006 & 0.75 & 0.75 & 0.4 \\
\hline & 2009 & 0.75 & 0.65 & 0.3 \\
\hline & 2012 & 0.65 & 0.4 & 0.25 \\
\hline \multirow{3}{*}{3} & 2006 & 0.65 & 0.65 & 0.4 \\
\hline & 2009 & 0.65 & 0.5 & 0.3 \\
\hline & 2012 & 0.55 & 0.35 & 0.25 \\
\hline \multirow{3}{*}{4} & 2006 & 0.6 & 0.4 & \multirow{2}{*}{ NR } \\
\hline & 2009 & 0.6 & 0.35 & \\
\hline & 2012 & 0.55 & 0.35 & 0.4 \\
\hline \multirow{3}{*}{5} & 2006 & 0.6 & 0.35 & \multirow{3}{*}{ NR } \\
\hline & 2009 & 0.6 & 0.35 & \\
\hline & 2012 & 0.55 & 0.32 & \\
\hline \multirow{3}{*}{6} & 2006 & 0.6 & 0.35 & \multirow{3}{*}{ NR } \\
\hline & 2009 & 0.6 & 0.35 & \\
\hline & 2012 & 0.55 & 0.32 & \\
\hline \multirow{3}{*}{7 and 8} & 2006 & 0.6 & 0.35 & \multirow{3}{*}{ NR } \\
\hline & 2009 & 0.6 & 0.35 & \\
\hline & 2012 & 0.55 & 0.32 & \\
\hline
\end{tabular}

Faithful+Gould report a cost separately for improving the U-factor and for improving the SHGC. The Faithful+Gould cost for SHGC improvement is used to cost the improvements in glazed fenestration requirements in climate zones 1 through 3 . The reduction of SHGC from 0.40 to 0.30 costs $\$ 2.77 / \mathrm{ft}^{2}$ and the reduction of SHGC from 0.30 to 0.25 costs $\$ 1.38 / \mathrm{ft}^{2}$. Because the low-E coating technology commonly used to achieve lower SHGC also lowers the U-factor, no additional cost is assumed for the improvements to U-factor required by the 2009 and 2012 IECC in climate zones 1 through 3 . The improvement of U-factor from 0.35 to 0.32 in climate zones 4 through 8 is assumed to cost $\$ 0.18 / \mathrm{ft}^{2}$ based on the Faithful+Gould cost estimate. The modest improvement in U-factor and SHGC in climate zone 4 required in the 2009 and 2012 IECC are assumed to have no incremental cost increase as most double-pane low-E windows will comply with the 2012 IECC requirements here.

\subsubsection{Above-Grade Wall Insulation}

Above grade walls in the single-family and multifamily building prototype models are assumed to be wood framed with fiberglass batt insulation. As such, all incremental cost calculations are carried out for 
fiberglass batt insulation. The 2009 IECC requires an increase of wall insulation from R-19 to R-20 ${ }^{1}$ in climate zones 5 and 6 compared to the 2006 IECC. Because fiberglass batts are not commonly manufactured at the R-20 level, the cost for R-21 batts is used. The incremental material cost of R-21 fiberglass batt insulation compared to R-19 was identified as $\$ 0.19 / \mathrm{ft}^{2}$ from the Home Depot website. ${ }^{2}$ A 10-percent markup is added to account for the installers profit (RS Means 2011). This results in an incremental cost of $\$ 0.21 / \mathrm{ft}^{2}$ used in this analysis. The ASHRAE 90.2 database (NAHB 2009) reports a similar cost of $\$ 0.18 / \mathrm{ft}^{2}$.

The 2012 IECC requires R-20 wall insulation in climate zones 3 and 4 . This is an increase from R-13 in the 2006 and 2009 IECC. Wall insulation up to R-13 can be installed using $2 \times 4$-in. wood framing members. $2 \times 4$-in. framing members are assumed to be spaced 16 in. on-center. R-20 cavity insulation has a greater thickness than R-13 and necessitates using $2 \times 6$ wood framing members. As $2 \times 6-$ in. framing allows for more structural stability, framing members are assumed to be spaced $24 \mathrm{in}$. oncenter. RS Means indicates the change from $2 \times 4$-in. framing to $2 \times 6$-in. framing with larger spacing has zero cost. Based on data from RS Means, the incremental cost for R-19 fiberglass batts over R-13 batts is $\$ 0.06 / \mathrm{ft}^{2}$. Thus, the total incremental cost for R-21 wall insulation over R-13 wall insulation is $\$ 0.27 / \mathrm{ft}^{2}$.

The 2012 IECC requires R-20 cavity insulation plus R-5 continuous insulation in climate zones 6 through 8. The 2006 and 2009 IECC do not require R-5 continuous insulation in these zones. Faithful+Gould reports a cost of $\$ 0.79 / \mathrm{ft}^{2}$ for a full layer of R-5 extruded polystyrene continuous insulation. This cost has been used here. The R-5 insulation is assumed to be in addition to structural sheathing such as oriented strand board (OSB) or plywood over the entire wall area. Alternative construction methods may allow the continuous insulation to replace some or all of the structural sheathing using bracing techniques such metal straps or using a combination of wood panel and insulating sheathing at corners of walls. This may allow lower construction costs, but may also modestly decrease energy efficiency. These alternatives are not analyzed here.

\subsubsection{Basement Wall Insulation}

The 2009 and 2012 IECC require basement walls to be insulated with either R-5 continuous insulation or R-13 cavity insulation in climate zone 3 above the "warm humid" line (e.g., northern Alabama and Mississippi) if the basement is conditioned. The 2006 IECC does not require basement wall insulation in this region. All versions of the IECC require basement wall insulation in climate zones 4 through 8 .

This analysis has assumed R-13 fiberglass batt or blanket products would be most likely used to meet basement wall insulation requirements in the IECC. Basement wall insulation is only required if the basement is conditioned, and if the basement is conditioned it is most likely to be finished. Hence, this analysis assumes no additional cost for finishing a basement. Faithful+Gould estimates the installed cost kraft-faced R-13 fiberglass batt at $\$ 0.517 / \mathrm{ft}^{2}$. Hence, an incremental cost of $\$ 0.51 / \mathrm{ft}^{2}$ of basement wall area is assumed in this analysis for R-13 insulation.

\footnotetext{
${ }^{1}$ The IECC permits the R-20 requirements to be met by R-13 cavity insulation plus R-5 continuous insulation.

${ }^{2}$ http://www.homedepot.com/. Last accessed February 27, 2012.
} 
The 2009 IECC requires R-15 continuous or R-19 cavity insulation in basement walls in climate zones 6 through 8 . The 2012 IECC extends this requirement to apply to climate zone 5 as well. This requirement also applies to crawlspace walls if the crawlspace is conditioned. The 2006 IECC only requires R-10 continuous or R-13 cavity insulation in these zones. Faithful+Gould estimate an incremental cost of $\$ 0.26 / \mathrm{ft}^{2}$ of basement wall area for $\mathrm{R}-19$ cavity insulation compared to $\mathrm{R}-13$. This estimate includes the additional cost of switching from $2 \times 4$-in. to $2 \times 6$-in. framing and is used in this analysis.

\subsubsection{Ceiling and Floor Insulation}

The 2009 and 2012 IECC require improved ceiling and floor insulation over the 2006 IECC in certain cliamte zones. Faithful+Gould estimates an incremental cost of $\$ 0.24 / \mathrm{ft}^{2}$ for $\mathrm{R}-38$ floor insulation compared to R-30. For ceiling insulation, Faithful+Gould estimates an incremental cost of $\$ 0.28 / \mathrm{ft}^{2}$ for $\mathrm{R}-38$ insulation compared to R-30 and $\$ 0.28 / \mathrm{ft}^{2}$ for $\mathrm{R}-49$ compared to $\mathrm{R}-38$. These costs are used in this analysis.

\subsubsection{Lighting}

The 2006 IECC does not contain any requirements for high- efficacy lamps. The 2009 and 2012 IECC require 50 percent and 75 percent, respectively, of lamps in permanently installed lighting fixtures to be high efficacy. Compact flourescent lamps (CFLs) will comply with the IECC high-efficacy lamp requirement. The high efficacy lighting requirements in the 2009 and 2012 IECC will become less relevant as the requirements of federal law, which will require improved efficiency in light bulbs sold in the United States, take effect in 2012 to 2014.

A study of 604 new single-family homes in the Pacific Northwest found that the average home has 49 light fixtures containing 77 bulbs (RLW Analytics 2007). The lighting energy use for the singlefamily and multifamily prototype building models is based on Building America house simulation protocols (Hendron and Engebrecht 2010). The protocols assume 16 percent of the lighting energy is plug-in. As the high-efficacy lighting requirement impacts permanently installed fixtures alone, the remaining 84 percent of lighting energy is assumed to be impacted by this requirement. This reduces the number of lamps impacted by the 2009 and 2012 IECC to 65 for the single-family home. Furthermore, the protocols assume 34 percent of all lighting in the benchmark home is already high efficacy. The benchmark home corresponds to the 2006 IECC case in this analysis. This translates to an estimate of 10 light bulbs being replaced with CFLs in the 2009 IECC cases and 27 bulbs in the 2012 IECC cases.

Faithful+Gould estimates standard incandescent bulbs cost $\$ 0.55$ to $\$ 0.78$ per bulb and CFL spiral lamps cost $\$ 3.87$ or less per bulb. An incremental estimate of $\$ 3.00$ per bulb is assumed in this analysis for high-efficiency lighting. These results in an incremental cost of $\$ 30$ per house for the 2009 IECC and $\$ 81$ per house for the 2012 IECC for high-efficacy lighting compared to incandescent lighting.

According to the Building America House Simulation Protocols, the lighting energy for the $1200-\mathrm{ft}^{2}$ dwelling unit in the multifamily prototype is 57 percent of the lighting energy of the $2400-\mathrm{ft}^{2}$ singlefamily prototype. The incremental lighting costs for multifamily are therefore scaled down to $\$ 14$ per house for the 2009 IECC and $\$ 47$ per house for the 2012 IECC. 


\subsubsection{Hot Water Pipe Insulation}

The 2006 and 2009 IECC have no requirements for hot water pipe insulation for non-circulating service water heating systems. The 2012 IECC requires R-3 insulation on most hot water pipes for service water use. The Lowes website ${ }^{1}$ reports a cost of $\$ 5.98$ for $6 \mathrm{ft}$ of R-3 pipe insulation, or about $\$ 1 / \mathrm{ft}$. Assuming there are $200 \mathrm{ft}$ of hot water pipe in a $2400-\mathrm{ft}^{2}$ home, the material cost would be $\$ 200$.

Klein (2012) reports costs of $\$ 136.40$ to $\$ 322.50$ for $\mathrm{R}-3$ insulation installed on hot water pipes in a new $2400-\mathrm{ft}^{2}$ home and $\$ 123.20$ to $\$ 168.00$ for pipe insulation in a $1200-\mathrm{ft}^{2}$ dwelling unit. A conservative estimate of $\$ 400$ (materials and labor) in incremental costs for the single-family prototype and $\$ 200$ for each dwelling unit in the multifamily prototype is used in this analysis for meeting the hot water piping insulation requirements in the 2012 IECC.

\subsubsection{Total Incremental Construction Costs - 2006 to 2009 IECC}

Table 6.4 and Table 6.5 summarize the incremental costs for the 2009 IECC over the 2006 IECC for the single-family and multifamily prototypes, respectively. Table 6.6 and Table 6.7 summarize the incremental costs for the 2012 IECC over the 2009 IECC for the single-family and multifamily prototypes, respectively.

\subsection{Location Indices}

The incremental construction costs are defined on a national average basis for each code improvement. Location multipliers for residential construction developed by Faithful+Gould are applied to the national average construction costs to derive the modified costs for a particular location. ${ }^{2}$ The location factors take into urban/rural factors, and regional construction pricing factors. Table 6.8 indicates the location multipliers for each state.

\footnotetext{
${ }^{1}$ Lowes http://www.lowes.com/. Last accessed February 28, 2012.

${ }^{2}$ Faithful+Gould Residential Energy Efficiency Measures: Location Factors http://bc3.pnnl.gov/wiki/images/7/7f/Location_Factors_Report.pdf.
} 
Table 6.4. Incremental Costs for the 2009 IECC over the 2006 IECC for the Single-family Prototype

\begin{tabular}{|c|c|c|c|c|c|c|c|c|c|c|}
\hline Climate Zone & Foundation Type & $\begin{array}{c}\text { Duct } \\
\text { Sealing and } \\
\text { Testing }\end{array}$ & $\begin{array}{l}\text { Improved } \\
\text { Air } \\
\text { Sealing }\end{array}$ & $\begin{array}{c}\text { R-19 to } \\
\text { R-20 } \\
\text { Walls }\end{array}$ & $\begin{array}{l}\text { Windows } \\
0.30 \\
\text { SHGC and } \\
\text { Lower U }\end{array}$ & $\begin{array}{c}\text { Windows } \\
\text { U-0.40 to } \\
0.35\end{array}$ & $\begin{array}{l}\text { R-30 to R-38 } \\
\text { Floors }\end{array}$ & $\begin{array}{l}\text { R-19 Basement } \\
\text { Wall Insulation }\end{array}$ & $\begin{array}{l}50 \% \text { Energy } \\
\text { Efficient } \\
\text { Lighting }\end{array}$ & Total \\
\hline 1 & All & $\$ 375$ & $\$ 120$ & & $\$ 989$ & & & & $\$ 30$ & $\$ 1,514$ \\
\hline 2 & All & $\$ 375$ & $\$ 120$ & & $\$ 989$ & & & & $\$ 30$ & $\$ 1,514$ \\
\hline 3 -South & All & $\$ 375$ & $\$ 120$ & & $\$ 989$ & & & & $\$ 30$ & $\$ 1,514$ \\
\hline 3 - North & Heated basements & $\$ 375$ & $\$ 120$ & & $\$ 989$ & & & $\$ 500$ & $\$ 30$ & $\$ 2,014$ \\
\hline 3 - North & $\begin{array}{l}\text { All but heated } \\
\text { basements }\end{array}$ & $\$ 375$ & $\$ 120$ & & $\$ 989$ & & & & $\$ 30$ & $\$ 1,514$ \\
\hline 4 & All & $\$ 375$ & $\$ 120$ & & & $\$ 104$ & & & $\$ 30$ & $\$ 629$ \\
\hline 5 & All & $\$ 375$ & $\$ 120$ & $\$ 414$ & & & & & $\$ 30$ & $\$ 939$ \\
\hline 6 & Heated basements & $\$ 375$ & $\$ 120$ & $\$ 414$ & & & & $\$ 255$ & $\$ 30$ & $\$ 1,194$ \\
\hline 6 & $\begin{array}{l}\text { All but heated } \\
\text { basements }\end{array}$ & $\$ 375$ & $\$ 120$ & $\$ 414$ & & & & & $\$ 30$ & $\$ 939$ \\
\hline 7 and 8 & Heated basements & $\$ 375$ & $\$ 120$ & & & & & $\$ 255$ & $\$ 30$ & $\$ 780$ \\
\hline 7 and 8 & $\begin{array}{l}\text { Floors over } \\
\text { unconditioned } \\
\text { spaces }\end{array}$ & $\$ 375$ & $\$ 120$ & & & & $\$ 288$ & & $\$ 30$ & $\$ 813$ \\
\hline 7 and 8 & Slab on grade & $\$ 375$ & $\$ 120$ & & & & & & $\$ 30$ & $\$ 525$ \\
\hline
\end{tabular}


Table 6.5. Incremental Costs for the 2009 IECC over the 2006 IECC for the Multifamily Prototype

\begin{tabular}{|c|c|c|c|c|c|c|c|c|c|c|}
\hline $\begin{array}{l}\text { Climate } \\
\text { Zone }\end{array}$ & Foundation Type & $\begin{array}{c}\text { Duct } \\
\text { Sealing and } \\
\text { Testing }\end{array}$ & $\begin{array}{c}\text { Improved } \\
\text { Air } \\
\text { Sealing }\end{array}$ & $\begin{array}{c}\text { R-19 to } \\
\text { R-20 } \\
\text { walls }\end{array}$ & $\begin{array}{c}\text { Windows } \\
0.30 \\
\text { SHGC and } \\
\text { Lower U }\end{array}$ & $\begin{array}{c}\text { Windows } \\
\text { U-0.40 to } \\
0.35\end{array}$ & $\begin{array}{l}\text { R-30 to R- } \\
38 \text { Floors }\end{array}$ & $\begin{array}{l}\text { R-19 Basement } \\
\text { Wall Insulation }\end{array}$ & $\begin{array}{c}50 \% \text { Energy } \\
\text { Efficient } \\
\text { Lighting }\end{array}$ & Total \\
\hline 1 & All & $\$ 255$ & $\$ 60$ & & $\$ 327$ & & & & $\$ 18$ & $\$ 660$ \\
\hline 2 & All & $\$ 255$ & $\$ 60$ & & $\$ 327$ & & & & $\$ 18$ & $\$ 660$ \\
\hline 3 - South & All & $\$ 255$ & $\$ 60$ & & $\$ 327$ & & & & $\$ 18$ & $\$ 660$ \\
\hline 3 - North & Heated basements & $\$ 255$ & $\$ 60$ & & $\$ 327$ & & & $\$ 73$ & $\$ 18$ & $\$ 733$ \\
\hline 3 - North & $\begin{array}{l}\text { All but heated } \\
\text { basements }\end{array}$ & $\$ 255$ & $\$ 60$ & & $\$ 327$ & & & & $\$ 18$ & $\$ 660$ \\
\hline 4 & All & $\$ 255$ & $\$ 60$ & & & $\$ 34$ & & & $\$ 18$ & $\$ 367$ \\
\hline 5 & All & $\$ 255$ & $\$ 60$ & $\$ 149$ & & & & & $\$ 18$ & $\$ 482$ \\
\hline 6 & Heated basements & $\$ 255$ & $\$ 60$ & $\$ 149$ & & & & $\$ 37$ & $\$ 18$ & $\$ 519$ \\
\hline 6 & $\begin{array}{l}\text { All but heated } \\
\text { basements }\end{array}$ & $\$ 255$ & $\$ 60$ & $\$ 149$ & & & & & $\$ 18$ & $\$ 482$ \\
\hline 7 and 8 & Heated basements & $\$ 255$ & $\$ 60$ & & & & & $\$ 37$ & $\$ 18$ & $\$ 370$ \\
\hline 7 and 8 & $\begin{array}{l}\text { Floors over } \\
\text { unconditioned } \\
\text { spaces }\end{array}$ & $\$ 255$ & $\$ 60$ & & & & $\$ 96$ & & $\$ 18$ & $\$ 429$ \\
\hline 7 and 8 & Slab on grade & $\$ 255$ & $\$ 60$ & & & & & & $\$ 18$ & $\$ 333$ \\
\hline
\end{tabular}


Table 6.6. Incremental Costs for the 2012 IECC over the 2009 IECC for the Single-Family Prototype

\begin{tabular}{|c|c|c|c|c|c|c|c|c|c|c|c|}
\hline $\begin{array}{l}\text { Climate } \\
\text { Zone }\end{array}$ & $\begin{array}{l}\text { Foundation } \\
\text { Type }\end{array}$ & $\begin{array}{l}\text { Envelope } \\
\text { Sealing }\end{array}$ & $\begin{array}{c}\text { Blower } \\
\text { Door Test }\end{array}$ & $\begin{array}{c}\text { Windows - } \\
0.25 \text { SHGC } \\
\text { and Lower U }\end{array}$ & $\begin{array}{l}\text { Increased } \\
\text { Ceiling } \\
\text { Insulation }\end{array}$ & $\begin{array}{c}\text { Increased } \\
\text { Wall } \\
\text { Insulation }\end{array}$ & $\begin{array}{l}\text { Hot Water } \\
\text { Pipe } \\
\text { Insulation }\end{array}$ & $\begin{array}{c}\text { Further } \\
\text { Duct } \\
\text { Sealing }\end{array}$ & $\begin{array}{c}75 \% \\
\text { Energy } \\
\text { Efficient } \\
\text { Lighting }\end{array}$ & $\begin{array}{c}\text { R-19 } \\
\text { Basement } \\
\text { Wall } \\
\text { Insulation }\end{array}$ & Total \\
\hline 1 & All & $\$ 480$ & $\$ 135$ & $\$ 493$ & & & $\$ 400$ & $\$ 100$ & $\$ 51$ & & $\$ 1,659$ \\
\hline 2 & All & $\$ 480$ & $\$ 135$ & $\$ 493$ & $\$ 336$ & & $\$ 400$ & $\$ 100$ & $\$ 51$ & & $\$ 1,995$ \\
\hline 3 & All & $\$ 480$ & $\$ 135$ & $\$ 493$ & $\$ 336$ & $\$ 533$ & $\$ 400$ & $\$ 100$ & $\$ 51$ & & $\$ 2,528$ \\
\hline 4 & All & $\$ 480$ & $\$ 135$ & & $\$ 336$ & $\$ 533$ & $\$ 400$ & $\$ 100$ & $\$ 51$ & & $\$ 2,035$ \\
\hline 5 & $\begin{array}{l}\text { Heated } \\
\text { basement }\end{array}$ & $\$ 480$ & $\$ 135$ & $\$ 64$ & $\$ 336$ & & $\$ 400$ & $\$ 100$ & $\$ 51$ & $\$ 255$ & $\$ 1,821$ \\
\hline 5 & $\begin{array}{l}\text { All but heated } \\
\text { basement }\end{array}$ & $\$ 480$ & $\$ 135$ & $\$ 64$ & $\$ 336$ & & $\$ 400$ & $\$ 100$ & $\$ 51$ & & $\$ 1,566$ \\
\hline 6,7 and 8 & All & $\$ 480$ & $\$ 135$ & $\$ 64$ & & $\$ 1,567$ & $\$ 400$ & $\$ 100$ & $\$ 51$ & & $\$ 2,797$ \\
\hline
\end{tabular}

Table 6.7. Incremental Costs for the 2012 IECC over the 2009 IECC for the Multifamily Prototype

\begin{tabular}{|c|c|c|c|c|c|c|c|c|c|c|c|}
\hline $\begin{array}{l}\text { Climate } \\
\text { Zone }\end{array}$ & $\begin{array}{c}\text { Foundation } \\
\text { Type }\end{array}$ & $\begin{array}{c}\text { Envelope } \\
\text { Sealing }\end{array}$ & $\begin{array}{c}\text { Blower } \\
\text { Door Test }\end{array}$ & $\begin{array}{c}\text { Windows - } \\
0.25 \text { SHGC } \\
\text { and Lower U }\end{array}$ & $\begin{array}{l}\text { Increased } \\
\text { Ceiling } \\
\text { Insulation }\end{array}$ & $\begin{array}{c}\text { Increased } \\
\text { Wall } \\
\text { Insulation }\end{array}$ & $\begin{array}{l}\text { Hot Water } \\
\text { Pipe } \\
\text { Insulation }\end{array}$ & $\begin{array}{l}\text { Further } \\
\text { Duct } \\
\text { Sealing }\end{array}$ & $\begin{array}{c}75 \% \\
\text { Energy } \\
\text { Efficient } \\
\text { Lighting }\end{array}$ & $\begin{array}{c}\text { R-19 } \\
\text { Basement } \\
\text { Wall } \\
\text { Insulation }\end{array}$ & Total \\
\hline 1 & All & $\$ 240$ & $\$ 135$ & $\$ 163$ & & & $\$ 200$ & $\$ 100$ & $\$ 29$ & & $\$ 867$ \\
\hline 2 & All & $\$ 240$ & $\$ 135$ & $\$ 163$ & $\$ 112$ & & $\$ 200$ & $\$ 100$ & $\$ 29$ & & $\$ 979$ \\
\hline 3 & All & $\$ 240$ & $\$ 135$ & $\$ 163$ & $\$ 112$ & $\$ 191$ & $\$ 200$ & $\$ 100$ & $\$ 29$ & & $\$ 1,170$ \\
\hline 4 & All & $\$ 240$ & $\$ 135$ & & $\$ 112$ & $\$ 191$ & $\$ 200$ & $\$ 100$ & $\$ 29$ & & $\$ 1,007$ \\
\hline 5 & $\begin{array}{l}\text { Heated } \\
\text { basement }\end{array}$ & $\$ 240$ & $\$ 135$ & $\$ 21$ & $\$ 112$ & & $\$ 200$ & $\$ 100$ & $\$ 29$ & $\$ 37$ & $\$ 874$ \\
\hline 5 & $\begin{array}{l}\text { All but } \\
\text { heated } \\
\text { basement }\end{array}$ & $\$ 240$ & $\$ 135$ & $\$ 21$ & $\$ 112$ & & $\$ 200$ & $\$ 100$ & $\$ 29$ & & $\$ 837$ \\
\hline 6,7 and 8 & All & $\$ 240$ & $\$ 135$ & $\$ 21$ & & $\$ 562$ & $\$ 200$ & $\$ 100$ & $\$ 29$ & & $\$ 1,287$ \\
\hline
\end{tabular}


Table 6.8. Construction Cost Multiplier by State

\begin{tabular}{|c|c|}
\hline State & Multiplier \\
\hline Alabama & 0.842 \\
\hline Alaska & 1.336 \\
\hline Arizona & 0.928 \\
\hline Arkansas & 0.839 \\
\hline California & 1.142 \\
\hline Colorado & 0.972 \\
\hline Connecticut & 1.124 \\
\hline Delaware & 1.053 \\
\hline District of Columbia & 0.999 \\
\hline Florida & 0.884 \\
\hline Georgia & 0.882 \\
\hline Hawaii & 1.288 \\
\hline Idaho & 0.918 \\
\hline Illinois & 1.069 \\
\hline Indiana & 0.99 \\
\hline Iowa & 0.946 \\
\hline Kansas & 0.869 \\
\hline Kentucky & 0.929 \\
\hline Louisiana & 0.853 \\
\hline Maine & 0.916 \\
\hline Maryland & 0.956 \\
\hline Massachusetts & 1.141 \\
\hline Michigan & 0.989 \\
\hline Minnesota & 1.06 \\
\hline Mississippi & 0.833 \\
\hline Missouri & 1.005 \\
\hline Montana & 0.936 \\
\hline Nebraska & 0.905 \\
\hline Nevada & 1.063 \\
\hline New Hampshire & 0.967 \\
\hline New Jersey & 1.156 \\
\hline New Mexico & 0.903 \\
\hline New York & 1.093 \\
\hline North Carolina & 0.838 \\
\hline North Dakota & 0.888 \\
\hline Ohio & 0.967 \\
\hline Oklahoma & 0.852 \\
\hline Oregon & 1.038 \\
\hline Pennsylvania & 1.025 \\
\hline Rhode Island & 1.082 \\
\hline South Carolina & 0.808 \\
\hline South Dakota & 0.829 \\
\hline Tennessee & 0.863 \\
\hline Texas & 0.837 \\
\hline Utah & 0.883 \\
\hline Vermont & 0.933 \\
\hline
\end{tabular}


Table 6.8. (contd)

\begin{tabular}{lc}
\hline \multicolumn{1}{c}{ State } & Multiplier \\
\hline Virginia & 0.887 \\
Washington & 1.034 \\
West Virginia & 0.979 \\
Wisconsin & 1.01 \\
Wyoming & 0.886 \\
\hline
\end{tabular}




\subsection{Cost-Effectiveness Calculations}

\subsection{Cost-Effectiveness Methodology}

DOE supports the development and adoption of more efficient building energy codes that are cost effective. The cost-effectiveness methodology lays out the entire procedure for computing cost effectiveness of the codes analyzed in this study.

\subsection{Calculation Structure}

Three cost-effectiveness metrics are computed as defined in the cost-effectiveness methodology: 1) LCC, 2) simple payback, and 3) annual consumer cash flow. LCC is the primary metric used by DOE to assess the cost effectiveness of a code. Simple payback and cash flow details are provided to assist states in assessing new codes.

LCC is computed using the annual energy savings and the incremental first cost associated with the efficiency improvements of a code. The LCC calculation is an assessment of the net benefit of code changes in present value terms over a defined period of analysis. Annualized cash flows are a component of the LCC calculation, but are presented year by year without discounting to present value. They help in determining the number of years needed to achieve positive cash flow (i.e., how long before the annual cost savings outweigh the incremental mortgage payments). Simple payback is the simple calculation of the number of years it would take the annual energy savings to break even with the incremental first cost. It does not account for the time-value of money or any other mortgage calculations.

The economic parameters used in the economic calculations are defined in the cost-effectiveness methodology. These are summarized again in Table 7.1. The cost-effectiveness methodology provides more details on the reasoning behind the selection of each value.

\subsection{Aggregation of Results}

The economic results from the 11,424 energy models are aggregated to three levels: 1) state, 2) climate zone, and 3) national. The aggregated results are based on weighted averages of the individual results, in which weightings are defined by the relative prevalence of foundation types, heating system types, and building types (single-family vs. multifamily) at the three levels. Weighting factors are developed from multiple data sources as documented in the cost-effectiveness methodology.

Figure 7.1 provides a high level overview of the aggregation process. The weighting factors used in this analysis are further described in the following sections. 
Annual heating, cooling, domestic hot water and lighting energy consumption from EnergyPlus (119 locations $\times 4$ foundations $\times$ 4 heating systems $\times 2$ prototypes) for the 2006, 2009 and 2012 IECC.

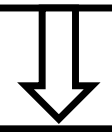

Annual Total Energy cost for each case based on state-wise fuel costs.

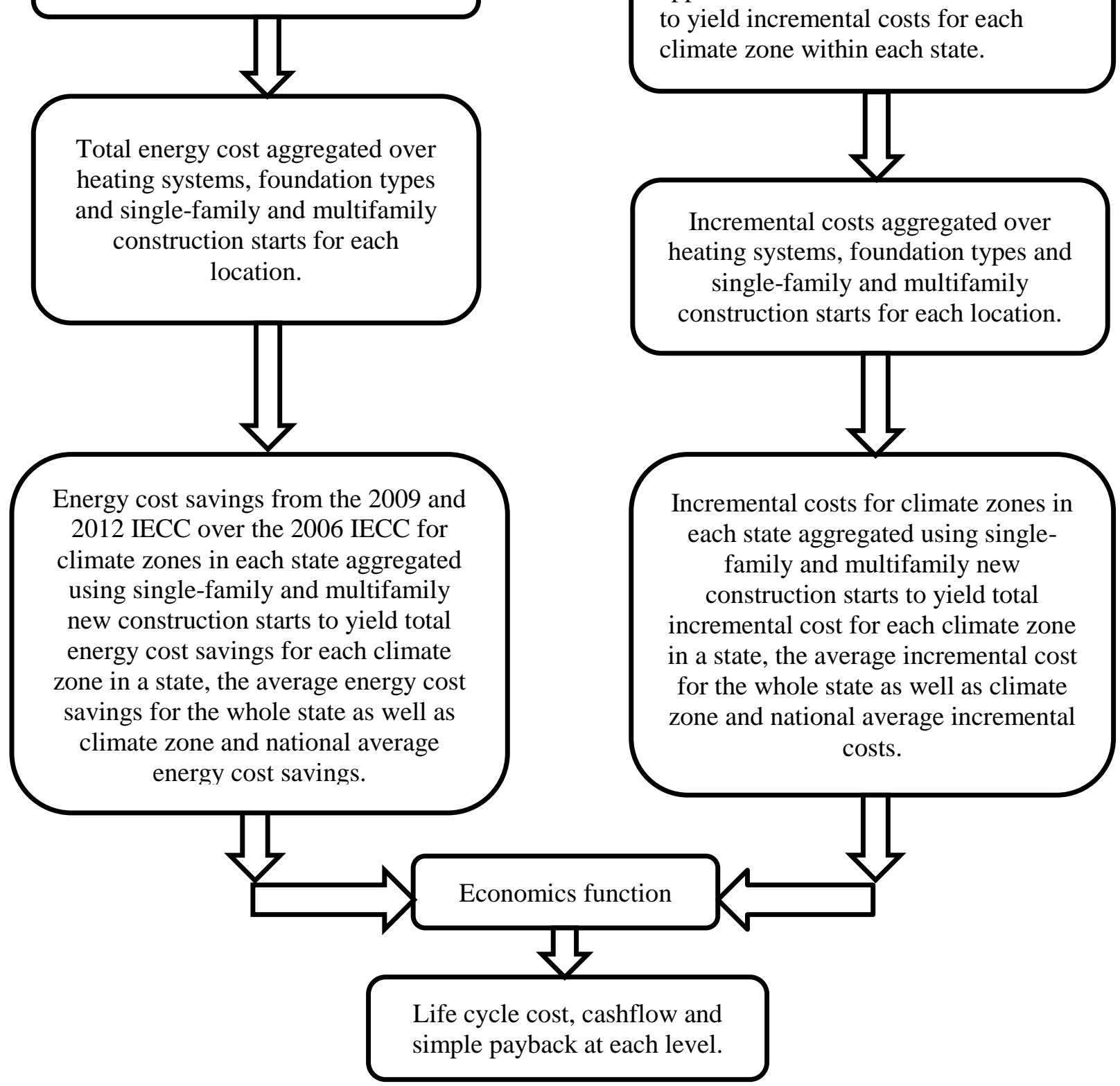

Figure 7.1. Overview of the Aggregation Process
Incremental Costs calculated for the 2009 and 2012 IECC over the 2006 IECC (119 locations $\times 4$ foundations $\times 2$ prototypes). Incremental costs do not change by heating system.

State-wise construction cost multipliers applied to zone-wise incremental costs to yield incremental costs for each climate zone within each state.

Incremental costs aggregated over eating systems, foundation types and single-family and multifamily construction starts for each location.

Incremental costs for climate zones in each state aggregated using single-

family and multifamily new construction starts to yield total incremental cost for each climate zone in a state, the average incremental cost for the whole state as well as climate zone and national average incremental costs. 
Table 7.1. Economic Parameters Used in LCC Calculations

\begin{tabular}{lcl}
\hline \multicolumn{1}{c}{ Parameter } & Symbol & \multicolumn{1}{c}{ Current Estimate } \\
\hline Mortgage Interest Rate & $\mathrm{R}_{\mathrm{MI}}$ & $5 \%$ \\
Loan Term & $\mathrm{T}$ & 30 years \\
Down Payment Rate & $\mathrm{R}_{\mathrm{DP}}$ & $10 \%$ of home price \\
Points and Loan Fees & $\mathrm{R}_{\mathrm{MF}}$ & $0.7 \%$ (non-deductible) \\
Discount Rate & $\mathrm{R}_{\mathrm{d}}$ & $5 \%$ (equal to Mortgage Interest Rate) \\
Period of Analysis & $\mathrm{P}$ & 30 years \\
Property Tax Rate & $\mathrm{R}_{\mathrm{PT}}$ & $0.9 \%$ of home price/value \\
Income Tax Rate & $\mathrm{R}_{\mathrm{IT}}$ & $25 \%$ federal, state values vary \\
Home Price Escalation Rate & $\mathrm{E}_{\mathrm{H}}$ & Equal to Inflation Rate \\
Inflation Rate & $\mathrm{R}_{\mathrm{INF}}$ & $1.6 \%$ annual \\
Fuel Prices and Escalation Rates & Latest state average residential prices are based on current Energy \\
& Information Administration data and projections (as of the end of \\
& 2011; fuel price escalation rates are from the 2012Annual Energy \\
& Outlook. (An average nominal escalation rate of 2.2\% is used in this \\
& analysis). \\
\hline
\end{tabular}

\subsubsection{Aggregation Across Foundation Types}

Residential buildings typically have one of three foundation types: 1) basement, 2) crawlspace, or 3) slab-on-grade. The basement may be heated or unheated. Data from DOE's 2009 Residential Energy Consumption Survey ${ }^{1}$ are used to establish foundation shares for both single-family and multifamily buildings. Table 7.2 details the foundation shares used in this analysis.

Table 7.2. Share of Foundation Types (percent)

\begin{tabular}{|c|c|c|c|c|}
\hline State & $\begin{array}{l}\text { Slab-on- } \\
\text { Grade }\end{array}$ & $\begin{array}{c}\text { Heated } \\
\text { Basement }\end{array}$ & $\begin{array}{l}\text { Unheated } \\
\text { Basement }\end{array}$ & Crawlspace \\
\hline $\begin{array}{l}\text { Connecticut, Rhode Island, Vermont, } \\
\text { New Hampshire, Maine }\end{array}$ & 16.8 & 23.8 & 45.5 & 13.9 \\
\hline Massachusetts & 15.8 & 21.2 & 51.9 & 11.2 \\
\hline New York & 20.4 & 25.9 & 41.7 & 12 \\
\hline New Jersey & 26.9 & 18.3 & 30.6 & 24.2 \\
\hline Pennsylvania & 28.9 & 24.6 & 32.8 & 13.7 \\
\hline Illinois & 22.5 & 39.4 & 14.1 & 24.1 \\
\hline Ohio and Indiana & 27.5 & 29.9 & 21.2 & 21.4 \\
\hline Michigan & 15.7 & 36.2 & 27.3 & 20.8 \\
\hline Wisconsin & 14.9 & 45 & 29.7 & 10.4 \\
\hline Minnesota, Iowa, North Dakota, South Dakota & 22.1 & 46.9 & 15.5 & 15.5 \\
\hline Kansas and Nebraska & 29.8 & 32.7 & 14.9 & 22.5 \\
\hline Missouri & 24.8 & 36.4 & 20.8 & 17.9 \\
\hline
\end{tabular}


Table 7.2. (contd)

\begin{tabular}{lcccc}
\hline \multicolumn{1}{c}{ State } & $\begin{array}{c}\text { Slab-on } \\
\text { Grade }\end{array}$ & $\begin{array}{c}\text { Heated } \\
\text { Basement }\end{array}$ & $\begin{array}{c}\text { Unheated } \\
\text { Basement }\end{array}$ & Crawlspace \\
\hline Virginia & 33.2 & 24.2 & 9.8 & 32.8 \\
Maryland, Delaware, and West Virginia & 28 & 30.7 & 18.3 & 23 \\
Georgia & 57.1 & 6.6 & 9.7 & 26.7 \\
North Carolina and South Carolina & 38.7 & 2.3 & 4.1 & 54.9 \\
Florida & 87.7 & 0 & 0.4 & 11.8 \\
Alabama, Mississippi, Kentucky & 44.1 & 8.6 & 10.6 & 36.7 \\
Tennessee & 35.3 & 7.2 & 9 & 48.4 \\
Arkansas, Louisiana, and Oklahoma & 66.9 & 0.6 & 2.9 & 29.7 \\
Texas & 79.6 & 0.3 & 0.4 & 19.8 \\
Colorado & 30.7 & 28.2 & 9.9 & 31.2 \\
Utah, Wyoming, Montana, Idaho & 26.7 & 36.6 & 11 & 25.6 \\
Arizona & 90.7 & 0.6 & 3.1 & 5.6 \\
Nevada and New Mexico & 86.1 & 2.5 & 0.8 & 10.7 \\
California & 59 & 1.2 & 4.9 & 34.9 \\
Washington, Oregon, Alaska, Hawaii & 37 & 8.9 & 3.1 & 51 \\
\hline
\end{tabular}

\subsubsection{Aggregation Across Heating System Types}

The next level of aggregation is done by heating system shares. Heating system shares used in DOE's analyses are taken from National Association of Home Builders survey data (NAHB 2009). The shares by heating system type for new construction in each census division for single-family and multifamily homes are shown in Table 7.3 and Table 7.4, respectively.

Table 7.3. Share of Heating Systems - Single-Family Home (percent)

\begin{tabular}{lcccc}
\hline \multicolumn{1}{c}{ Census Division } & Electric Heat Pump & Gas Heating & Oil Heating & Electric Furnace \\
\hline New England & 10.8 & 57 & 31.1 & 1.1 \\
Middle Atlantic & 24.5 & 69.2 & 4.6 & 1.7 \\
East North Central & 22.5 & 76.2 & 0.5 & 0.7 \\
West North Central & 39.6 & 56.7 & 0.2 & 3.4 \\
South Atlantic & 78.9 & 19 & 0.1 & 2 \\
East South Central & 68.9 & 28.9 & 0 & 2.1 \\
West South Central & 37.5 & 48.1 & 0 & 14.5 \\
Mountain & 19.4 & 77.8 & 0.2 & 2.6 \\
Pacific & 34 & 62.9 & 0.2 & 2.9 \\
\hline
\end{tabular}


Table 7.4. Share of Heating Systems - Multifamily Home (percent)

\begin{tabular}{lcccc}
\hline \multicolumn{1}{c}{ Census Division } & Electric Heat Pump & Gas Heating & Oil Heating & Electric Furnace \\
\hline New England & 3 & 66 & 30.4 & 0.7 \\
Middle Atlantic & 39.5 & 49.6 & 6.1 & 4.9 \\
East North Central & 3.3 & 96.5 & 0.1 & 0.1 \\
West North Central & 24.8 & 68 & 3 & 4.3 \\
South Atlantic & 74.9 & 24.2 & 0 & 1.1 \\
East South Central & 94.1 & 1.8 & 0 & 4.1 \\
West South Central & 6.9 & 10.1 & $52.9^{1}$ & 30.2 \\
Mountain & 2.8 & 97.2 & 0 & 0 \\
Pacific & 14.9 & 84.2 & 0.2 & 0.8 \\
\hline
\end{tabular}

\subsubsection{Aggregation Across Building Types}

Finally, new housing construction starts from the census data at the county level for $2010^{2}$ are used to estimate single-family and multifamily shares within each climate location within each state. Table 7.5 shows the single-family and multifamily building new housing construction starts for each state - climate zone combination.

Table 7.5. New Housing Construction Starts from the 2010 Census Data

\begin{tabular}{lcrr}
\hline \multicolumn{1}{c}{ State } & Climate Zone & $\begin{array}{c}\text { Single Family } \\
\text { Permits }\end{array}$ & $\begin{array}{c}\text { Multifamily } \\
\text { Permits }\end{array}$ \\
\hline Alabama & 2 & 1,577 & 94 \\
Alabama & 3 & 5,531 & 764 \\
Alabama & $3 \mathrm{WH}$ & 1,594 & 798 \\
Alaska & 7 & 601 & 41 \\
Alaska & 8 & 65 & 0 \\
Arizona & 2 & 9,409 & 719 \\
Arizona & 3 & 696 & 28 \\
Arizona & 4 & 307 & 58 \\
Arizona & 5 & 343 & 88 \\
Arkansas & 3 & 3,454 & 1,512 \\
Arkansas & $3 \mathrm{WH}$ & 51 & 5 \\
Arkansas & 4 & 1,143 & 119 \\
California & 2 & 102 & 0 \\
California & $3 \mathrm{~B}$ & 21,167 & 6,513 \\
California & $3 \mathrm{C}$ & 3,585 & 3,416 \\
California & 4B & 384 & 3
\end{tabular}

\footnotetext{
${ }^{1}$ DOE believes there is either an error or an anomaly in the source table resulting in a large overstatement in oil heating use in the West South Central region. The value, 52.9 percent, is set to zero, and the shares for the other fuel/equipment types are renormalized to sum to $100 \%$ for purposes of DOE's analyses.

${ }^{2}$ United States Census Bureau Building Permits; Accessed April 27, 2012 at http://censtats.census.gov/bldg/bldgprmt.shtml.
} 
Table 7.5 (contd)

\begin{tabular}{|c|c|c|c|}
\hline State & Climate Zone & $\begin{array}{c}\text { Single Family } \\
\text { Permits }\end{array}$ & $\begin{array}{c}\text { Multifamily } \\
\text { Permits }\end{array}$ \\
\hline California & $4 \mathrm{C}$ & 196 & 13 \\
\hline California & 5 & 233 & 21 \\
\hline California & 6 & 26 & 0 \\
\hline Colorado & 4 & 23 & 1 \\
\hline Colorado & 5 & 7,760 & 1,514 \\
\hline Colorado & 6 & 462 & 8 \\
\hline Colorado & 7 & 545 & 26 \\
\hline Connecticut & 5 & 2,632 & 569 \\
\hline Delaware & 4 & 2,673 & 258 \\
\hline District Of Columbia & 4 & 177 & 364 \\
\hline Florida & 1 & 2,045 & 1,680 \\
\hline Florida & 2 & 27,995 & 3,909 \\
\hline Georgia & 2 & 2,915 & 501 \\
\hline Georgia & 3 & 9,245 & 931 \\
\hline Georgia & $3 \mathrm{WH}$ & 1,487 & 133 \\
\hline Georgia & 4 & 1,132 & 44 \\
\hline Hawaii & 1 & 2,203 & 515 \\
\hline Idaho & 5 & 2,669 & 154 \\
\hline Idaho & 6 & 899 & 169 \\
\hline Illinois & 4 & 1,736 & 538 \\
\hline Illinois & 5 & 5,888 & 2,757 \\
\hline Indiana & 4 & 1,924 & 188 \\
\hline Indiana & 5 & 7,849 & 2,135 \\
\hline Iowa & 5 & 4,956 & 1,100 \\
\hline Iowa & 6 & 996 & 62 \\
\hline Kansas & 4 & 3,926 & 796 \\
\hline Kansas & 5 & 48 & 22 \\
\hline Kentucky & 4 & 5,983 & 1,296 \\
\hline Louisiana & 2 & 7,723 & 481 \\
\hline Louisiana & 3 & 20 & 1 \\
\hline Louisiana & $3 \mathrm{WH}$ & 2,467 & 251 \\
\hline Maine & 6 & 2,636 & 89 \\
\hline Maine & 7 & 75 & 8 \\
\hline Maryland & 4 & 8,394 & 2,227 \\
\hline Maryland & 5 & 95 & 0 \\
\hline Massachusetts & 5 & 5,839 & 1,417 \\
\hline Michigan & 5 & 6,041 & 830 \\
\hline Michigan & 6 & 1,426 & 84 \\
\hline Michigan & 7 & 236 & 12 \\
\hline Minnesota & 6 & 5,440 & 1,839 \\
\hline Minnesota & 7 & 1,613 & 117 \\
\hline Mississippi & 2 & 1,765 & 351 \\
\hline Mississippi & 3 & 1,769 & 91 \\
\hline
\end{tabular}


Table 7.5 (contd)

\begin{tabular}{|c|c|c|c|}
\hline State & Climate Zone & $\begin{array}{l}\text { Single Family } \\
\text { Permits }\end{array}$ & $\begin{array}{l}\text { Multifamily } \\
\text { Permits }\end{array}$ \\
\hline Mississippi & $3 \mathrm{WH}$ & 893 & 96 \\
\hline Missouri & 4 & 6,660 & 1,922 \\
\hline Missouri & 5 & 241 & 42 \\
\hline Montana & 6 & 1,322 & 387 \\
\hline Nebraska & 5 & 3,779 & 1,139 \\
\hline Nevada & 3 & 4,623 & 471 \\
\hline Nevada & 5 & 738 & 128 \\
\hline New Hampshire & 5 & 1,146 & 213 \\
\hline New Hampshire & 6 & 744 & 128 \\
\hline New Jersey & 4 & 5,024 & 1,873 \\
\hline New Jersey & 5 & 2,354 & 824 \\
\hline New Mexico & 3 & 953 & 130 \\
\hline New Mexico & 4 & 1,282 & 115 \\
\hline New Mexico & 5 & 927 & 46 \\
\hline New York & 4 & 1,810 & 2,964 \\
\hline New York & 5 & 5,702 & 987 \\
\hline New York & 6 & 2,447 & 257 \\
\hline North Carolina & 3 & 9,552 & 2,358 \\
\hline North Carolina & $3 \mathrm{WH}$ & 3,657 & 373 \\
\hline North Carolina & 4 & 12,419 & 2,263 \\
\hline North Carolina & 5 & 419 & 80 \\
\hline North Dakota & 6 & 789 & 191 \\
\hline North Dakota & 7 & 1,295 & 1,037 \\
\hline Ohio & 4 & 953 & 213 \\
\hline Ohio & 5 & 9,650 & 1,968 \\
\hline Oklahoma & 3 & 6,864 & 824 \\
\hline Oklahoma & 4 & 2 & 0 \\
\hline Oregon & 4 & 4,435 & 852 \\
\hline Oregon & 5 & 741 & 36 \\
\hline Pennsylvania & 4 & 3,821 & 540 \\
\hline Pennsylvania & 5 & 12,472 & 710 \\
\hline Pennsylvania & 6 & 593 & 0 \\
\hline Rhode Island & 5 & 727 & 91 \\
\hline South Carolina & 3 & 7,979 & 574 \\
\hline South Carolina & $3 \mathrm{WH}$ & 4,712 & 287 \\
\hline South Dakota & 5 & 171 & 28 \\
\hline South Dakota & 6 & 2,015 & 505 \\
\hline Tennessee & 3 & 1,463 & 576 \\
\hline Tennessee & 4 & 10,167 & 2,559 \\
\hline Texas & $2 \mathrm{~B}$ & 44,064 & 7,604 \\
\hline Texas & $2 \mathrm{~A}$ & 870 & 56 \\
\hline Texas & 3B & 314 & 234 \\
\hline Texas & $3 \mathrm{~A}$ & 15,908 & 3,887 \\
\hline Texas & $3 \mathrm{AWH}$ & 5,181 & 1,842 \\
\hline
\end{tabular}


Table 7.5 (contd)

\begin{tabular}{lcrc}
\hline \multicolumn{1}{c}{ State } & Climate Zone & $\begin{array}{c}\text { Single Family } \\
\text { Permits }\end{array}$ & $\begin{array}{c}\text { Multifamily } \\
\text { Permits }\end{array}$ \\
\hline Texas & $4 \mathrm{~B}$ & 636 & 280 \\
Utah & 3 & 873 & 11 \\
Utah & 5 & 5,084 & 857 \\
Utah & 6 & 9,26 & 398 \\
Vermont & 6 & 980 & 148 \\
Virginia & 4 & 13,820 & 1,948 \\
Washington & 4 & 10,550 & 2,464 \\
Washington & 5 & 3,889 & 845 \\
Washington & 6 & 263 & 3 \\
West Virginia & 4 & 1,139 & 150 \\
West Virginia & 5 & 657 & 237 \\
Wisconsin & 6 & 6,735 & 2,216 \\
Wisconsin & 7 & 952 & 15 \\
Wyoming & 5 & 18 & 4 \\
Wyoming & 6 & 1,366 & 388 \\
Wyoming & 7 & 162 & 24 \\
\hline
\end{tabular}




\subsection{Summary of Results}

\subsection{Energy Cost Savings}

Table 8.1 through Table 8.3 summarize the combined energy cost savings of the single-family and multifamily prototypes for the 2009 and 2012 IECC compared to the 2006 IECC at the national, climate zone, and state levels. Table 8.4 through Table 8.6 summarize the combined energy cost savings for the 2012 IECC compared to the 2009 IECC. The savings calculation includes only space heating, space cooling, domestic water heating, and lighting energy costs.

Table 8.1. National Energy Cost Savings for the 2009 and 2012 IECC Compared to the 2006 IECC

\begin{tabular}{lcc}
\hline & 2009 IECC & 2012 IECC \\
\hline $\begin{array}{l}\text { National Energy Cost Savings over } \\
\text { the 2006 IECC }\end{array}$ & $10.8 \%(\$ 168)$ & $32.1 \%(\$ 500)$ \\
\hline
\end{tabular}

Table 8.2. Energy Cost Savings by Climate Zone for the 2009 and 2012 IECC Compared to the 2006

\begin{tabular}{|c|c|c|c|c|}
\hline \multirow[t]{3}{*}{ Climate Zone } & \multicolumn{4}{|c|}{ Energy Cost Savings over the 2006 IECC } \\
\hline & \multicolumn{2}{|c|}{2009 IECC } & \multicolumn{2}{|c|}{2012 IECC } \\
\hline & Savings (\%) & Savings (\$) & Savings (\%) & Savings (\$) \\
\hline Zone 1 & 9.6 & 213 & 25.1 & 557 \\
\hline Zone 2 & 12.8 & 186 & 26.3 & 383 \\
\hline Zone 3 & 12.3 & 164 & 34 & 454 \\
\hline Zone 4 & 9.4 & 143 & 32.7 & 498 \\
\hline Zone 5 & 9.5 & 167 & 33 & 577 \\
\hline Zone 6 & 10 & 200 & 36.2 & 725 \\
\hline Zone 7 & 10 & 215 & 37.6 & 807 \\
\hline Zone 8 & 10.3 & 502 & 38.3 & 1862 \\
\hline
\end{tabular}

Table 8.3. Energy Cost Savings by State and Climate Zone for the 2009 and 2012 IECC Compared to the 2006 IECC

\begin{tabular}{lrrrr}
\hline \multirow{2}{*}{ State - Climate Zone } & \multicolumn{4}{c}{ Energy Cost Savings over the 2006 IECC } \\
\cline { 2 - 5 } & \multicolumn{2}{c}{2009 IECC } & \multicolumn{2}{c}{ 2012 IECC } \\
& Savings (\%) & Savings (\$) & Savings (\%) & Savings (\$) \\
\hline Alabama-2AWH & 11.9 & 173 & 26.1 & 380 \\
Alabama-3A & 11.9 & 177 & 34.3 & 509 \\
Alabama-3AWH & 11.1 & 139 & 31.5 & 395 \\
Alabama & 11.8 & 168 & 32.4 & 462 \\
Alaska-7A & 10.1 & 324 & 37.2 & 1190 \\
Alaska-8A & 10.3 & 502 & 38.3 & 1862 \\
Alaska & 10.1 & 340 & 37.3 & 1251 \\
Arizona-2B & 13.8 & 240 & 27.5 & 478 \\
Arizona-3B & 12.8 & 220 & 37.7 & 650 \\
Arizona-4B & 9.1 & 131 & 33 & 473 \\
Arizona-5B & 8.6 & 117 & 28.6 & 391 \\
\hline
\end{tabular}


Table 8.3. (contd)

\begin{tabular}{|c|c|c|c|c|}
\hline \multirow[t]{3}{*}{ State - Climate Zone } & \multicolumn{4}{|c|}{ Energy Cost Savings over the 2006 IECC } \\
\hline & \multicolumn{2}{|c|}{2009 IECC } & \multicolumn{2}{|c|}{2012 IECC } \\
\hline & Savings (\%) & Savings (\$) & Savings $(\%)$ & Savings (\$) \\
\hline Arizona & 13.5 & 231 & 28.3 & 486 \\
\hline Arkansas-3A & 11.7 & 146 & 35.9 & 448 \\
\hline Arkansas-3AWH & 11.7 & 149 & 34.8 & 441 \\
\hline Arkansas-4A & 10 & 151 & 35.7 & 539 \\
\hline Arkansas & 11.3 & 147 & 35.8 & 466 \\
\hline California-2B & 14.3 & 294 & 28.1 & 578 \\
\hline California-3B & 13.8 & 138 & 28.5 & 286 \\
\hline California-3C & 12.3 & 116 & 35.2 & 331 \\
\hline California-4B & 8.5 & 144 & 29.7 & 504 \\
\hline California-4C & 9.2 & 119 & 29.8 & 385 \\
\hline California-5B & 8.9 & 163 & 28.9 & 531 \\
\hline California-6B & 9.4 & 219 & 34.3 & 799 \\
\hline California & 13.4 & 135 & 29.8 & 301 \\
\hline Colorado-4B & 9.9 & 141 & 34.1 & 486 \\
\hline Colorado-5B & 9.3 & 116 & 30.3 & 377 \\
\hline Colorado-6B & 9.6 & 146 & 33.7 & 514 \\
\hline Colorado-7B & 9.4 & 148 & 34.3 & 540 \\
\hline Colorado & 9.3 & 119 & 30.7 & 392 \\
\hline Connecticut-5A & 9.6 & 237 & 32.7 & 811 \\
\hline Connecticut & 9.6 & 237 & 32.7 & 811 \\
\hline Delaware-4A & 10.3 & 249 & 35.8 & 865 \\
\hline Delaware & 10.3 & 249 & 35.8 & 865 \\
\hline DistrictofColumbia-4A & 8.7 & 125 & 29.9 & 429 \\
\hline District of Columbia & 8.7 & 125 & 29.9 & 429 \\
\hline Florida-1AWH & 9.3 & 115 & 25 & 309 \\
\hline Florida-2AWH & 13.3 & 190 & 25.1 & 360 \\
\hline Florida & 12.9 & 182 & 25.1 & 355 \\
\hline Georgia-2AWH & 12.2 & 166 & 26.1 & 354 \\
\hline Georgia-3A & 12.3 & 184 & 35.4 & 530 \\
\hline Georgia-3AWH & 11.6 & 168 & 32.8 & 474 \\
\hline Georgia-4A & 8.5 & 125 & 29.7 & 436 \\
\hline Georgia & 12 & 175 & 32.9 & 481 \\
\hline Hawaii-1A & 9.7 & 347 & 25.1 & 897 \\
\hline Hawaii & 9.7 & 347 & 25.1 & 897 \\
\hline Idaho-5B & 9.1 & 108 & 31.1 & 369 \\
\hline Idaho-6B & 9.9 & 133 & 35.8 & 481 \\
\hline Idaho & 9.3 & 114 & 32.4 & 399 \\
\hline Illinois-4A & 9.5 & 136 & 32.6 & 466 \\
\hline Illinois-5A & 9.3 & 129 & 31.3 & 437 \\
\hline Illinois & 9.3 & 130 & 31.6 & 443 \\
\hline Indiana-4A & 9.6 & 130 & 34 & 459 \\
\hline Indiana-5A & 9.5 & 131 & 33 & 454 \\
\hline Indiana & 9.5 & 130 & 33.1 & 454 \\
\hline Iowa-5A & 9.8 & 172 & 33.8 & 595 \\
\hline Iowa-6A & 10.3 & 234 & 38.1 & 865 \\
\hline Iowa & 9.8 & 181 & 34.5 & 635 \\
\hline Kansas-4A & 9.9 & 155 & 34.9 & 544 \\
\hline Kansas-5A & 9.4 & 133 & 32.4 & 461 \\
\hline Kansas & 10 & 155 & 34.9 & 543 \\
\hline Kentucky-4A & 10.1 & 143 & 34.9 & 492 \\
\hline Kentucky & 10.1 & 143 & 34.9 & 492 \\
\hline
\end{tabular}


Table 8.3. (contd)

\begin{tabular}{|c|c|c|c|c|}
\hline \multirow[t]{3}{*}{ State - Climate Zone } & \multicolumn{4}{|c|}{ Energy Cost Savings over the 2006 IECC } \\
\hline & \multicolumn{2}{|c|}{2009 IECC } & \multicolumn{2}{|c|}{2012 IECC } \\
\hline & Savings (\%) & Savings (\$) & Savings $(\%)$ & Savings (\$) \\
\hline Louisiana-2AWH & 12.2 & 149 & 26.9 & 330 \\
\hline Louisiana-3A & 12 & 152 & 34.9 & 443 \\
\hline Louisiana-3AWH & 11.8 & 151 & 34.8 & 444 \\
\hline Louisiana & 12 & 149 & 28.9 & 358 \\
\hline Maine-6A & 10.2 & 294 & 37.7 & 1086 \\
\hline Maine-7A & 10.2 & 370 & 39.1 & 1423 \\
\hline Maine & 10.2 & 297 & 37.7 & 1097 \\
\hline Maryland-4A & 9.7 & 202 & 33.3 & 691 \\
\hline Maryland-5A & 9.8 & 274 & 34 & 954 \\
\hline Maryland & 9.8 & 203 & 33.3 & 694 \\
\hline Massachusetts-5A & 10.1 & 243 & 35.9 & 864 \\
\hline Massachusetts & 10.1 & 243 & 35.9 & 864 \\
\hline Michigan-5A & 10 & 206 & 34.9 & 717 \\
\hline Michigan-6A & 10.4 & 233 & 37.4 & 836 \\
\hline Michigan-7A & 10.3 & 248 & 38.1 & 921 \\
\hline Michigan & 10.1 & 212 & 35.5 & 744 \\
\hline Minnesota-6A & 10 & 192 & 36.3 & 700 \\
\hline Minnesota-7A & 10.3 & 260 & 38.8 & 983 \\
\hline Minnesota & 10 & 205 & 36.9 & 754 \\
\hline Mississippi-2AWH & 11.9 & 146 & 25.8 & 317 \\
\hline Mississippi-3A & 12.5 & 186 & 35.2 & 524 \\
\hline Mississippi-3AWH & 11.8 & 161 & 33.3 & 456 \\
\hline Mississippi & 12.1 & 164 & 31.2 & 422 \\
\hline Missouri-4A & 9.6 & 142 & 34.1 & 504 \\
\hline Missouri-5A & 9.4 & 168 & 33.8 & 605 \\
\hline Missouri & 9.6 & 143 & 34.1 & 507 \\
\hline Montana-6B & 9.6 & 125 & 34.1 & 444 \\
\hline Montana & 9.6 & 125 & 34.1 & 444 \\
\hline Nebraska-5A & 9.3 & 133 & 32 & 458 \\
\hline Nebraska & 9.3 & 133 & 32 & 458 \\
\hline Nevada-3B & 13.5 & 219 & 36.3 & 590 \\
\hline Nevada-5B & 8.9 & 126 & 29.5 & 419 \\
\hline Nevada & 12.8 & 205 & 35.4 & 565 \\
\hline NewHampshire-5A & 9.3 & 223 & 33.1 & 795 \\
\hline NewHampshire-6A & 9.9 & 265 & 35.8 & 959 \\
\hline New Hampshire & 9.5 & 239 & 34.2 & 859 \\
\hline NewJersey-4A & 10.1 & 216 & 34.5 & 741 \\
\hline NewJersey-5A & 9.5 & 201 & 32.1 & 681 \\
\hline New Jersey & 9.9 & 211 & 33.8 & 722 \\
\hline NewMexico-3B & 13.3 & 191 & 38 & 545 \\
\hline NewMexico-4B & 9 & 112 & 31.3 & 388 \\
\hline NewMexico-5B & 8.9 & 110 & 27.7 & 343 \\
\hline New Mexico & 10.5 & 137 & 32.7 & 425 \\
\hline NewYork-4A & 9.3 & 161 & 31.2 & 543 \\
\hline NewYork-5A & 10 & 269 & 34.5 & 925 \\
\hline NewYork-6A & 10.2 & 277 & 36.4 & 985 \\
\hline New York & 9.9 & 234 & 34.1 & 808 \\
\hline NorthCarolina-3A & 11.6 & 151 & 33.5 & 437 \\
\hline NorthCarolina-3AWH & 11.6 & 152 & 32.7 & 429 \\
\hline NorthCarolina-4A & 8.8 & 118 & 30 & 403 \\
\hline NorthCarolina-5A & 9.2 & 153 & 32.2 & 537 \\
\hline
\end{tabular}


Table 8.3. (contd)

\begin{tabular}{|c|c|c|c|c|}
\hline \multirow[t]{3}{*}{ State - Climate Zone } & \multicolumn{4}{|c|}{ Energy Cost Savings over the 2006 IECC } \\
\hline & \multicolumn{2}{|c|}{2009 IECC } & \multicolumn{2}{|c|}{2012 IECC } \\
\hline & Savings (\%) & Savings (\$) & Savings $(\%)$ & Savings (\$) \\
\hline North Carolina & 10.2 & 136 & 31.7 & 422 \\
\hline NorthDakota-6A & 10 & 169 & 36.6 & 620 \\
\hline NorthDakota-7A & 9.5 & 141 & 36.1 & 535 \\
\hline North Dakota & 9.6 & 149 & 36.2 & 560 \\
\hline Ohio-4A & 10 & 159 & 35.1 & 556 \\
\hline Ohio-5A & 9.3 & 136 & 31.3 & 460 \\
\hline Ohio & 9.4 & 139 & 31.7 & 469 \\
\hline Oklahoma-3A & 12.5 & 190 & 39 & 591 \\
\hline Oklahoma-4B & 10.1 & 145 & 35.4 & 508 \\
\hline Oklahoma & 12.5 & 190 & 39 & 591 \\
\hline Oregon-4C & 8.7 & 100 & 30.2 & 346 \\
\hline Oregon-5B & 9.6 & 153 & 33.7 & 534 \\
\hline Oregon & 8.8 & 106 & 30.8 & 370 \\
\hline Pennsylvania-4A & 10.1 & 192 & 35.3 & 671 \\
\hline Pennsylvania-5A & 9.3 & 204 & 33.1 & 724 \\
\hline Pennsylvania-6A & 10 & 250 & 37.3 & 931 \\
\hline Pennsylvania & 9.5 & 203 & 33.8 & 718 \\
\hline RhodeIsland-5A & 9.8 & 249 & 34.6 & 878 \\
\hline Rhode Island & 9.8 & 249 & 34.6 & 878 \\
\hline SouthCarolina-3A & 11.8 & 176 & 34 & 507 \\
\hline SouthCarolina-3AWH & 11.8 & 166 & 32.3 & 456 \\
\hline South Carolina & 11.8 & 173 & 33.4 & 488 \\
\hline SouthDakota-5A & 10 & 173 & 35.6 & 617 \\
\hline SouthDakota-6A & 10.1 & 168 & 36.4 & 609 \\
\hline South Dakota & 10 & 168 & 36.4 & 609 \\
\hline Tennessee-3A & 12.1 & 154 & 34.7 & 442 \\
\hline Tennessee-4A & 8.9 & 118 & 31.1 & 410 \\
\hline Tennessee & 9.4 & 123 & 31.6 & 415 \\
\hline Texas-2AWH & 12.4 & 182 & 26.6 & 389 \\
\hline Texas-2BWH & 12.9 & 207 & 27.1 & 434 \\
\hline Texas-3A & 12.2 & 180 & 36.4 & 537 \\
\hline Texas-3AWH & 12 & 192 & 35.7 & 571 \\
\hline Texas-3B & 12.4 & 165 & 33.9 & 452 \\
\hline Texas-4B & 9.8 & 152 & 34.2 & 529 \\
\hline Texas & 12.3 & 183 & 29.7 & 442 \\
\hline Utah-3B & 14.7 & 198 & 37 & 498 \\
\hline Utah-5B & 8.8 & 103 & 29.7 & 349 \\
\hline Utah-6B & 8.9 & 97 & 31.3 & 340 \\
\hline Utah & 9.5 & 112 & 30.8 & 363 \\
\hline Vermont-6A & 10.2 & 297 & 37.3 & 1089 \\
\hline Vermont & 10.2 & 297 & 37.3 & 1089 \\
\hline Virginia-4A & 9.1 & 138 & 31.9 & 482 \\
\hline Virginia & 9.1 & 138 & 31.9 & 482 \\
\hline Washington-4C & 9.1 & 97 & 31.8 & 339 \\
\hline Washington-5B & 9.8 & 148 & 34.7 & 522 \\
\hline Washington-6B & 9.7 & 175 & 36.6 & 662 \\
\hline Washington & 9.4 & 112 & 32.9 & 392 \\
\hline WestVirginia-4A & 9.5 & 141 & 33.7 & 501 \\
\hline WestVirginia-5A & 8.9 & 126 & 31.8 & 450 \\
\hline West Virginia & 9.3 & 135 & 32.9 & 480 \\
\hline Wisconsin-6A & 9.7 & 189 & 35.4 & 688 \\
\hline
\end{tabular}


Table 8.3. (contd)

\begin{tabular}{lrrrr}
\hline \multirow{2}{*}{ State - Climate Zone } & \multicolumn{4}{c}{ Energy Cost Savings over the 2006 IECC } \\
\cline { 2 - 5 } & \multicolumn{2}{c}{ 2009 IECC } & \multicolumn{3}{c}{ 2012 IECC } \\
\hline Wisconsin-7A & Savings (\%) & Savings (\$) & Savings (\%) & Savings (\$) \\
Wisconsin & 10.4 & 274 & 38.9 & 1022 \\
Wyoming-5B & 9.8 & 197 & 35.8 & 720 \\
Wyoming-6B & 9.5 & 123 & 32.8 & 426 \\
Wyoming-7B & 10.3 & 129 & 36.7 & 458 \\
Wyoming & 9.6 & 144 & 36.2 & 540 \\
\hline
\end{tabular}

Table 8.4. National Energy Cost Savings for the 2012 IECC Compared to the 2009 IECC 2012 IECC

National Energy Cost Savings over $23.9 \%$ (\$332)
the 2009 IECC

Table 8.5. Energy Cost Savings by Climate Zone for the 2012 IECC Compared to the 2009 IECC

\begin{tabular}{lcc}
\hline \multicolumn{1}{r}{ Climate Zone } & Energy Cost Savings of the 2012 IECC over the 2009 IECC \\
\hline & Savings (\%) & Savings (\$) \\
\hline Zone 1 & 17.1 & 344 \\
Zone 2 & 15.5 & 197 \\
Zone 3 & 24.8 & 290 \\
Zone 4 & 25.7 & 355 \\
Zone 5 & 25.9 & 410 \\
Zone 6 & 29.2 & 525 \\
Zone 7 & 30.6 & 592 \\
Zone 8 & 31.2 & 1360 \\
\hline
\end{tabular}

Table 8.6. Energy Cost Savings by State and Climate Zone for the 2012 IECC Compared to the 2009 IECC

\begin{tabular}{lcc}
\hline \multirow{2}{*}{ State - Climate Zone } & \multicolumn{2}{c}{ Energy Cost Savings of the 2012 IECC over the 2009 IECC } \\
\cline { 2 - 3 } & Savings (\%) & Savings (\$) \\
\hline Alabama-2AWH & 16.1 & 207 \\
Alabama-3A & 25.4 & 332 \\
Alabama-3AWH & 22.9 & 256 \\
Alabama & 23.4 & 294 \\
Alaska-7A & 30.1 & 866 \\
Alaska-8A & 31.2 & 1360 \\
Alaska & 30.3 & 911 \\
Arizona-2B & 15.9 & 238 \\
Arizona-3B & 28.6 & 430 \\
Arizona-4B & 26.3 & 342 \\
Arizona-5B & 21.9 & 274 \\
\hline
\end{tabular}


Table 8.6. (contd)

\begin{tabular}{|c|c|c|}
\hline \multirow[t]{2}{*}{ State - Climate Zone } & \multicolumn{2}{|c|}{ Energy Cost Savings of the 2012 IECC over the 2009 IECC } \\
\hline & Savings $(\%)$ & Savings (\$) \\
\hline Arizona & 17.2 & 255 \\
\hline Arkansas-3A & 27.4 & 302 \\
\hline Arkansas-3AWH & 26.1 & 292 \\
\hline Arkansas-4A & 28.6 & 388 \\
\hline Arkansas & 27.6 & 319 \\
\hline California-2B & 16.1 & 284 \\
\hline California-3B & 17.1 & 148 \\
\hline California-3C & 26.1 & 215 \\
\hline California-4B & 23.2 & 360 \\
\hline California-4C & 22.7 & 266 \\
\hline California-5B & 21.9 & 368 \\
\hline California-6B & 27.5 & 580 \\
\hline California & 19 & 166 \\
\hline Colorado-4B & 26.9 & 345 \\
\hline Colorado-5B & 23.1 & 261 \\
\hline Colorado-6B & 26.7 & 368 \\
\hline Colorado-7B & 27.5 & 392 \\
\hline Colorado & 23.6 & 273 \\
\hline Connecticut-5A & 25.6 & 574 \\
\hline Connecticut & 25.6 & 574 \\
\hline Delaware-4A & 28.4 & 616 \\
\hline Delaware & 28.4 & 616 \\
\hline DistrictofColumbia-4A & 23.2 & 304 \\
\hline District of Columbia & 23.2 & 304 \\
\hline Florida-1AWH & 17.3 & 194 \\
\hline Florida-2AWH & 13.7 & 170 \\
\hline Florida & 14.1 & 173 \\
\hline Georgia-2AWH & 15.8 & 188 \\
\hline Georgia-3A & 26.3 & 346 \\
\hline Georgia-3AWH & 24 & 306 \\
\hline Georgia-4A & 23.2 & 311 \\
\hline Georgia & 23.8 & 306 \\
\hline Hawaii-1A & 17 & 550 \\
\hline Hawaii & 17 & 550 \\
\hline Idaho-5B & 24.2 & 261 \\
\hline Idaho-6B & 28.8 & 348 \\
\hline Idaho & 25.5 & 285 \\
\hline Illinois-4A & 25.5 & 330 \\
\hline Illinois-5A & 24.3 & 308 \\
\hline Illinois & 24.6 & 313 \\
\hline Indiana-4A & 27 & 329 \\
\hline Indiana-5A & 25.9 & 323 \\
\hline Indiana & 26.1 & 324 \\
\hline Iowa-5A & 26.6 & 423 \\
\hline Iowa-6A & 31 & 631 \\
\hline Iowa & 27.4 & 454 \\
\hline Kansas-4A & 27.7 & 389 \\
\hline Kansas-5A & 25.5 & 328 \\
\hline Kansas & 27.7 & 388 \\
\hline
\end{tabular}


Table 8.6. (contd)

\begin{tabular}{|c|c|c|}
\hline \multirow[t]{2}{*}{ State - Climate Zone } & \multicolumn{2}{|c|}{ Energy Cost Savings of the 2012 IECC over the 2009 IECC } \\
\hline & Savings $(\%)$ & Savings (\$) \\
\hline Kentucky-4A & 27.6 & 349 \\
\hline Kentucky & 27.6 & 349 \\
\hline Louisiana-2AWH & 16.8 & 181 \\
\hline Louisiana-3A & 26.1 & 291 \\
\hline Louisiana-3AWH & 26.1 & 293 \\
\hline Louisiana & 19.2 & 209 \\
\hline Maine-6A & 30.6 & 792 \\
\hline Maine-7A & 32.3 & 1053 \\
\hline Maine & 30.7 & 800 \\
\hline Maryland-4A & 26.1 & 489 \\
\hline Maryland-5A & 26.8 & 680 \\
\hline Maryland & 26.1 & 491 \\
\hline Massachusetts-5A & 28.7 & 621 \\
\hline Massachusetts & 28.7 & 621 \\
\hline Michigan-5A & 27.7 & 511 \\
\hline Michigan-6A & 30.1 & 603 \\
\hline Michigan-7A & 31 & 673 \\
\hline Michigan & 28.3 & 532 \\
\hline Minnesota-6A & 29.3 & 508 \\
\hline Minnesota-7A & 31.8 & 723 \\
\hline Minnesota & 29.9 & 549 \\
\hline Mississippi-2AWH & 15.8 & 171 \\
\hline Mississippi-3A & 26 & 338 \\
\hline Mississippi-3AWH & 24.4 & 295 \\
\hline Mississippi & 21.7 & 258 \\
\hline Missouri-4A & 27.1 & 362 \\
\hline Missouri-5A & 26.9 & 437 \\
\hline Missouri & 27.1 & 364 \\
\hline Montana-6B & 27.1 & 319 \\
\hline Montana & 27.1 & 319 \\
\hline Nebraska-5A & 25 & 325 \\
\hline Nebraska & 25 & 325 \\
\hline Nevada-3B & 26.4 & 371 \\
\hline Nevada-5B & 22.6 & 293 \\
\hline Nevada & 25.9 & 360 \\
\hline NewHampshire-5A & 26.3 & 572 \\
\hline NewHampshire-6A & 28.7 & 694 \\
\hline New Hampshire & 27.3 & 620 \\
\hline NewJersey-4A & 27.2 & 525 \\
\hline NewJersey-5A & 25 & 480 \\
\hline New Jersey & 26.5 & 511 \\
\hline NewMexico-3B & 28.5 & 354 \\
\hline NewMexico-4B & 24.5 & 276 \\
\hline NewMexico-5B & 20.6 & 233 \\
\hline New Mexico & 24.7 & 288 \\
\hline NewYork-4A & 24.2 & 382 \\
\hline NewYork-5A & 27.2 & 656 \\
\hline NewYork-6A & 29.2 & 708 \\
\hline New York & 26.9 & 574 \\
\hline
\end{tabular}


Table 8.6. (contd)

\begin{tabular}{|c|c|c|}
\hline \multirow[t]{2}{*}{ State - Climate Zone } & \multicolumn{2}{|c|}{ Energy Cost Savings of the 2012 IECC over the 2009 IECC } \\
\hline & Savings $(\%)$ & Savings (\$) \\
\hline NorthCarolina-3A & 24.8 & 286 \\
\hline NorthCarolina-3AWH & 23.9 & 277 \\
\hline NorthCarolina-4A & 23.3 & 285 \\
\hline NorthCarolina-5A & 25.4 & 384 \\
\hline North Carolina & 24 & 286 \\
\hline NorthDakota-6A & 29.6 & 451 \\
\hline NorthDakota-7A & 29.4 & 394 \\
\hline North Dakota & 29.4 & 411 \\
\hline Ohio-4A & 27.8 & 397 \\
\hline Ohio-5A & 24.3 & 324 \\
\hline Ohio & 24.6 & 330 \\
\hline Oklahoma-3A & 30.3 & 401 \\
\hline Oklahoma-4B & 28.2 & 363 \\
\hline Oklahoma & 30.3 & 401 \\
\hline Oregon-4C & 23.5 & 246 \\
\hline Oregon-5B & 26.6 & 381 \\
\hline Oregon & 24.1 & 264 \\
\hline Pennsylvania-4A & 28 & 479 \\
\hline Pennsylvania-5A & 26.2 & 520 \\
\hline Pennsylvania-6A & 30.3 & 681 \\
\hline Pennsylvania & 26.8 & 515 \\
\hline RhodeIsland-5A & 27.5 & 629 \\
\hline Rhode Island & 27.5 & 629 \\
\hline SouthCarolina-3A & 25.2 & 331 \\
\hline SouthCarolina-3AWH & 23.3 & 290 \\
\hline South Carolina & 24.4 & 315 \\
\hline SouthDakota-5A & 28.5 & 444 \\
\hline SouthDakota-6A & 29.3 & 441 \\
\hline South Dakota & 29.3 & 441 \\
\hline Tennessee-3A & 25.7 & 288 \\
\hline Tennessee-4A & 24.3 & 292 \\
\hline Tennessee & 24.5 & 292 \\
\hline Texas-2AWH & 16.2 & 207 \\
\hline Texas-2BWH & 16.3 & 227 \\
\hline Texas-3A & 27.6 & 357 \\
\hline Texas-3AWH & 26.9 & 379 \\
\hline Texas-3B & 24.5 & 287 \\
\hline Texas-4B & 27 & 377 \\
\hline Texas & 19.8 & 259 \\
\hline Utah-3B & 26.1 & 300 \\
\hline Utah-5B & 23 & 246 \\
\hline Utah-6B & 24.6 & 243 \\
\hline Utah & 23.5 & 251 \\
\hline Vermont-6A & 30.2 & 792 \\
\hline Vermont & 30.2 & 792 \\
\hline Virginia-4A & 25.1 & 344 \\
\hline Virginia & 25.1 & 344 \\
\hline Washington-4C & 25 & 242 \\
\hline Washington-5B & 27.6 & 374 \\
\hline
\end{tabular}


Table 8.6. (contd)

\begin{tabular}{lcc}
\hline \multirow{2}{*}{ State - Climate Zone } & Energy Cost Savings of the 2012 IECC over the 2009 IECC \\
\cline { 2 - 3 } & Savings (\%) & Savings (\$) \\
\hline Washington-6B & 29.8 & 487 \\
Washington & 25.9 & 280 \\
WestVirginia-4A & 26.7 & 360 \\
WestVirginia-5A & 25.2 & 324 \\
West Virginia & 26.1 & 345 \\
Wisconsin-6A & 28.4 & 499 \\
Wisconsin-7A & 31.8 & 748 \\
Wisconsin & 28.8 & 523 \\
Wyoming-5B & 25.7 & 303 \\
Wyoming-6B & 29.4 & 329 \\
Wyoming-7B & 29.4 & 396 \\
Wyoming & 29.4 & 335 \\
\end{tabular}

\subsection{Cost Effectiveness}

Table 8.7 and Table 8.8 summarize the life cycle cost savings of the 2009 and 2012 IECC compared to the 2006 IECC at the climate zone and state levels. Table 8.9 summarizes the life cycle cost savings of the 2012 IECC compared to the 2009 IECC.

Table 8.7. Life Cycle Cost Savings by Climate Zone for the 2009 and 2012 IECC compared to the 2006 IECC (2012 dollars)

\begin{tabular}{lcc}
\hline & \multicolumn{2}{c}{ Life Cycle Cost Savings over the 2006 IECC (\$) } \\
\cline { 2 - 3 } Climate Zone & 2009 IECC & 2012 IECC \\
\hline Zone 1 & 2,877 & 8,256 \\
Zone 2 & 2,443 & 4,763 \\
Zone 3 & 1,944 & 5,720 \\
Zone 4 & 2,259 & 7,706 \\
Zone 5 & 2,486 & 9,229 \\
Zone 6 & 3,114 & 11,366 \\
Zone 7 & 3,622 & 13,166 \\
Zone 8 & 9,147 & 33,105 \\
\hline
\end{tabular}

Table 8.8. Life Cycle Cost Savings by State and Climate Zone for the 2009 and 2012 IECC compared to the 2006 IECC (2012 dollars)

\begin{tabular}{lcc}
\hline & \multicolumn{2}{c}{ Life Cycle Cost Savings over the 2006 IECC (\$) } \\
\cline { 2 - 3 } State - Climate Zone & 2009 IECC & 2012 IECC \\
\hline Alabama-2AWH & 2,149 & 4,666
\end{tabular}


Table 8.8. (contd)

\begin{tabular}{|c|c|c|}
\hline \multirow[b]{2}{*}{ State - Climate Zone } & \multicolumn{2}{|c|}{ Life Cycle Cost Savings over the 2006 IECC (\$) } \\
\hline & 2009 IECC & 2012 IECC \\
\hline Alabama-3A & 2,250 & 6,992 \\
\hline Alabama-3AWH & 1,679 & 5,113 \\
\hline Alabama & 2,117 & 6,182 \\
\hline Alaska-7A & 5,537 & 19,525 \\
\hline Alaska-8A & 9,124 & 32,986 \\
\hline Alaska & 5,861 & 20,745 \\
\hline Arizona-2B & 3,386 & 6,339 \\
\hline Arizona-3B & 2,946 & 9,353 \\
\hline Arizona-4B & 2,017 & 7,223 \\
\hline Arizona-5B & 1,538 & 5,727 \\
\hline Arizona & 3,245 & 6,550 \\
\hline Arkansas-3A & 1,814 & 6,167 \\
\hline Arkansas-3AWH & 1,707 & 5,627 \\
\hline Arkansas-4A & 2,491 & 8,742 \\
\hline Arkansas & 1,948 & 6,679 \\
\hline California-2B & 4,109 & 7,557 \\
\hline California-3B & 1,187 & 1,711 \\
\hline California-3C & 994 & 3,259 \\
\hline California-4B & 2,106 & 7,168 \\
\hline California-4C & 1,622 & 4,832 \\
\hline California-5B & 2,251 & 7,978 \\
\hline California-6B & 3,355 & 12,100 \\
\hline California & 1,192 & 2,136 \\
\hline Colorado-4B & 2,162 & 7,233 \\
\hline Colorado-5B & 1,469 & 5,246 \\
\hline Colorado-6B & 1,963 & 6,820 \\
\hline Colorado-7B & 2,261 & 7,641 \\
\hline Colorado & 1,528 & 5,435 \\
\hline Connecticut-5A & 3,793 & 13,709 \\
\hline Connecticut & 3,793 & 13,709 \\
\hline Delaware-4A & 4,316 & 14,778 \\
\hline Delaware & 4,316 & 14,778 \\
\hline District of Columbia-4A & 2,024 & 6,852 \\
\hline District of Columbia & 2,024 & 6,852 \\
\hline Florida-1AWH & 1,203 & 3,870 \\
\hline Florida-2AWH & 2,453 & 4,141 \\
\hline Florida & 2,320 & 4,147 \\
\hline Georgia-2AWH & 2,024 & 4,167 \\
\hline Georgia-3A & 2,326 & 7,222 \\
\hline Georgia-3AWH & 2,012 & 6,095 \\
\hline Georgia-4A & 1,900 & 6,471 \\
\hline Georgia & 2,210 & 6,415 \\
\hline Hawaii-1A & 5,150 & 14,238 \\
\hline
\end{tabular}


Table 8.8. (contd)

\begin{tabular}{|c|c|c|}
\hline \multirow[b]{2}{*}{ State - Climate Zone } & \multicolumn{2}{|c|}{ Life Cycle Cost Savings over the 2006 IECC (\$) } \\
\hline & 2009 IECC & 2012 IECC \\
\hline Hawaii & 5,150 & 14,238 \\
\hline Idaho-5B & 1,322 & 5,116 \\
\hline Idaho-6B & 1,821 & 6,629 \\
\hline Idaho & 1,444 & 5,515 \\
\hline Illinois-4A & 2,058 & 6,839 \\
\hline Illinois-5A & 1,728 & 6,419 \\
\hline Illinois & 1,784 & 6,506 \\
\hline Indiana-4A & 1,934 & 6,685 \\
\hline Indiana-5A & 1,782 & 6,804 \\
\hline Indiana & 1,781 & 6,764 \\
\hline Iowa-5A & 2,655 & 9,764 \\
\hline Iowa-6A & 3,773 & 14,134 \\
\hline Iowa & 2,823 & 10,416 \\
\hline Kansas-4A & 2,571 & 8,850 \\
\hline Kansas-5A & 1,979 & 7,371 \\
\hline Kansas & 2,556 & 8,828 \\
\hline Kentucky-4A & 2,279 & 7,646 \\
\hline Kentucky & 2,279 & 7,646 \\
\hline Louisiana-2AWH & 1,665 & 3,621 \\
\hline Louisiana-3A & 1,708 & 5,508 \\
\hline Louisiana-3AWH & 1,722 & 5,622 \\
\hline Louisiana & 1,663 & 4,107 \\
\hline Maine-6A & 5,054 & 18,719 \\
\hline Maine-7A & 6,798 & 25,830 \\
\hline Maine & 5,109 & 18,944 \\
\hline Maryland-4A & 3,453 & 11,627 \\
\hline Maryland-5A & 4,620 & 16,781 \\
\hline Maryland & 3,473 & 11,688 \\
\hline Massachusetts-5A & 3,914 & 14,777 \\
\hline Massachusetts & 3,914 & 14,777 \\
\hline Michigan-5A & 3,255 & 12,029 \\
\hline Michigan-6A & 3,707 & 13,331 \\
\hline Michigan-7A & 4,241 & 15,263 \\
\hline Michigan & 3,363 & 12,346 \\
\hline Minnesota-6A & 2,905 & 10,737 \\
\hline Minnesota-7A & 4,448 & 16,385 \\
\hline Minnesota & 3,196 & 11,817 \\
\hline Mississippi-2AWH & 1,716 & 3,605 \\
\hline Mississippi-3A & 2,393 & 7,196 \\
\hline Mississippi-3AWH & 1,955 & 5,933 \\
\hline Mississippi & 2,022 & 5,400 \\
\hline Missouri-4A & 2,224 & 7,766 \\
\hline Missouri-5A & 2,494 & 9,779 \\
\hline Missouri & 2,229 & 7,826 \\
\hline
\end{tabular}


Table 8.8. (contd)

\begin{tabular}{|c|c|c|}
\hline \multirow[b]{2}{*}{ State - Climate Zone } & \multicolumn{2}{|c|}{ Life Cycle Cost Savings over the 2006 IECC (\$) } \\
\hline & 2009 IECC & 2012 IECC \\
\hline Montana-6B & 1,668 & 5,920 \\
\hline Montana & 1,668 & 5,920 \\
\hline Nebraska-5A & 1,908 & 7,141 \\
\hline Nebraska & 1,908 & 7,141 \\
\hline Nevada-3B & 2,720 & 7,616 \\
\hline Nevada-5B & 1,565 & 5,846 \\
\hline Nevada & 2,543 & 7,352 \\
\hline New Hampshire-5A & 3,616 & 13,673 \\
\hline New Hampshire-6A & 4,423 & 16,024 \\
\hline New Hampshire & 3,925 & 14,573 \\
\hline New Jersey-4A & 3,638 & 12,221 \\
\hline New Jersey-5A & 3,078 & 11,094 \\
\hline New Jersey & 3,445 & 11,877 \\
\hline NewMexico-3B & 2,472 & 7,501 \\
\hline NewMexico-4B & 1,631 & 5,483 \\
\hline NewMexico-5B & 1,368 & 4,650 \\
\hline New Mexico & 1,835 & 5,897 \\
\hline NewYork-4A & 2,675 & 8,890 \\
\hline NewYork-5A & 4,474 & 16,071 \\
\hline NewYork-6A & 4,537 & 16,124 \\
\hline New York & 3,870 & 13,677 \\
\hline NorthCarolina-3A & 1,830 & 5,738 \\
\hline NorthCarolina-3AWH & 1,769 & 5,399 \\
\hline NorthCarolina-4A & 1,826 & 6,050 \\
\hline NorthCarolina-5A & 2,354 & 8,878 \\
\hline North Carolina & 1,844 & 5,911 \\
\hline NorthDakota-6A & 2,545 & 9,518 \\
\hline NorthDakota-7A & 2,283 & 8,416 \\
\hline North Dakota & 2,353 & 8,719 \\
\hline Ohio-4A & 2,561 & 8,834 \\
\hline Ohio-5A & 1,887 & 6,939 \\
\hline Ohio & 1,959 & 7,120 \\
\hline Oklahoma-3A & 2,526 & 8,621 \\
\hline Oklahoma-4B & 2,318 & 7,958 \\
\hline Oklahoma & 2,526 & 8,621 \\
\hline Oregon-4C & 1,341 & 4,428 \\
\hline Oregon-5B & 2,139 & 8,217 \\
\hline Oregon & 1,422 & 4,917 \\
\hline Pennsylvania-4A & 3,187 & 10,923 \\
\hline Pennsylvania-5A & 3,160 & 11,996 \\
\hline Pennsylvania-6A & 4,009 & 15,015 \\
\hline Pennsylvania & 3,189 & 11,845 \\
\hline RhodeIsland-5A & 4,043 & 15,074 \\
\hline Rhode Island & 4,043 & 15,074 \\
\hline
\end{tabular}


Table 8.8. (contd)

\begin{tabular}{|c|c|c|}
\hline \multirow[b]{2}{*}{ State - Climate Zone } & \multicolumn{2}{|c|}{ Life Cycle Cost Savings over the 2006 IECC (\$) } \\
\hline & 2009 IECC & 2012 IECC \\
\hline SouthCarolina-3A & 2,276 & 7,034 \\
\hline SouthCarolina-3AWH & 2,071 & 5,999 \\
\hline South Carolina & 2,215 & 6,650 \\
\hline SouthDakota-5A & 2,734 & 10,369 \\
\hline SouthDakota-6A & 2,583 & 9,473 \\
\hline South Dakota & 2,583 & 9,514 \\
\hline Tennesse-3A & 1,863 & 5,795 \\
\hline Tennesse- $4 \mathrm{~A}$ & 1,804 & 6,114 \\
\hline Tennessee & 1,809 & 6,102 \\
\hline Texas-2AWH & 2,394 & 4,933 \\
\hline Texas-2BWH & 2,821 & 5,705 \\
\hline Texas-3A & 2,558 & 8,117 \\
\hline Texas-3AWH & 2,637 & 8,363 \\
\hline Texas-3B & 2,127 & 6,069 \\
\hline Texas-4B & 2,536 & 8,705 \\
\hline Texas & 2,433 & 5,942 \\
\hline Utah-3B & 2,420 & 6,280 \\
\hline Utah-5B & 1,278 & 4,863 \\
\hline Utah-6B & 1,163 & 4,102 \\
\hline Utah & 1,385 & 4,879 \\
\hline Vermont-6A & 5,133 & 18,861 \\
\hline Vermont & 5,133 & 18,861 \\
\hline Virginia-4A & 2,186 & 7,487 \\
\hline Virginia & 2,186 & 7,487 \\
\hline Washington-4C & 1,255 & 4,223 \\
\hline Washington-5B & 2,059 & 8,029 \\
\hline Washington-6B & 2,502 & 9,533 \\
\hline Washington & 1,498 & 5,299 \\
\hline WestVirginia-4A & 2,184 & 7,627 \\
\hline WestVirginia-5A & 1,729 & 6,852 \\
\hline West Virginia & 1,996 & 7,301 \\
\hline Wisconsin-6A & 2,883 & 10,652 \\
\hline Wisconsin-7A & 4,731 & 17,223 \\
\hline Wisconsin & 3,056 & 11,272 \\
\hline Wyoming-5B & 1,675 & 6,404 \\
\hline Wyoming-6B & 1,754 & 6,268 \\
\hline Wyoming-7B & 2,238 & 7,977 \\
\hline Wyoming & 1,809 & 6,441 \\
\hline
\end{tabular}


Table 8.9. Life Cycle Cost Savings by State and Climate Zone for the 2012 IECC compared to the 2009 IECC (2012 dollars)

\begin{tabular}{lc}
\hline State - Climate Zone & Life Cycle Cost Savings over the 2009 IECC (\$) \\
\hline Alabama-2AWH & 2447 \\
Alabama-3A & 4672 \\
Alabama & 3996 \\
Alaska-7A & 13922 \\
Alaska-8A & 23806 \\
Alaska & 14819 \\
Arizona-2B & 2926 \\
Arizona-3B & 6322 \\
Arizona-4B & 5146 \\
Arizona-5B & 4187 \\
Arizona & 3255 \\
Arkansas-3A & 4294 \\
Arkansas-3AWH & 3850 \\
Arkansas-4A & 6222 \\
Arkansas & 4680 \\
California-2B & 3377 \\
California-3B & 438 \\
California-3C & 2200 \\
California-4B & 4995 \\
California-4C & 3139 \\
California-5B & 5706 \\
California-6B & 8721 \\
California & 878 \\
Colorado-4B & 5019 \\
Colorado-5B & 3768 \\
Colorado-6B & 4833 \\
Colorado-7B & 5343 \\
Colorado & 3895 \\
Connecticut-5A & 9903 \\
Connecticut & 9903 \\
Delaware-4A & 10409 \\
Delaware & 10409 \\
District of Columbia-4A & 4796 \\
District of Columbia & 4796 \\
\hline & 2641 \\
Georgia-2AWH & 1639 \\
\hline Flida-2AWH & 1769 \\
\hline
\end{tabular}


Table 8.9 (contd)

\begin{tabular}{|c|c|}
\hline State - Climate Zone & Life Cycle Cost Savings over the 2009 IECC (\$) \\
\hline Georgia-3A & 4822 \\
\hline Georgia-3AWH & 3998 \\
\hline Georgia-4A & 4523 \\
\hline Georgia & 4136 \\
\hline Hawaii-1A & 9044 \\
\hline Hawaii & 9044 \\
\hline Idaho-5B & 3786 \\
\hline Idaho-6B & 4798 \\
\hline Idaho & 4057 \\
\hline Illinois-4A & 4726 \\
\hline Illinois-5A & 4687 \\
\hline Illinois & 4704 \\
\hline Indiana-4A & 4704 \\
\hline Indiana-5A & 5032 \\
\hline Indiana & 4966 \\
\hline Iowa-5A & 7105 \\
\hline Iowa-6A & 10349 \\
\hline Iowa & 7573 \\
\hline Kansas-4A & 6235 \\
\hline Kansas-5A & 5403 \\
\hline Kansas & 6234 \\
\hline Kentucky-4A & 5321 \\
\hline Kentucky & 5321 \\
\hline Louisiana-2AWH & 1911 \\
\hline Louisiana-3A & 3726 \\
\hline Louisiana-3AWH & 3818 \\
\hline Louisiana & 2386 \\
\hline Maine-6A & 13639 \\
\hline Maine-7A & 18995 \\
\hline Maine & 13803 \\
\hline Maryland-4A & 8127 \\
\hline Maryland-5A & 12162 \\
\hline Maryland & 8169 \\
\hline Massachusetts-5A & 10848 \\
\hline Massachusetts & 10848 \\
\hline Michigan-5A & 8753 \\
\hline Michigan-6A & 9591 \\
\hline Michigan-7A & 10993 \\
\hline Michigan & 8972 \\
\hline Minnesota-6A & 7821 \\
\hline
\end{tabular}


Table 8.9 (contd)

\begin{tabular}{|c|c|}
\hline State - Climate Zone & Life Cycle Cost Savings over the 2009 IECC (\$) \\
\hline Minnesota-7A & 11880 \\
\hline Minnesota & 8592 \\
\hline Mississippi-2AWH & 1847 \\
\hline Mississippi-3A & 4723 \\
\hline Mississippi-3AWH & 3908 \\
\hline Mississippi & 3334 \\
\hline Missouri-4A & 5496 \\
\hline Missouri-5A & 7262 \\
\hline Missouri & 5539 \\
\hline Montana-6B & 4244 \\
\hline Montana & 4244 \\
\hline Nebraska-5A & 5224 \\
\hline Nebraska & 5224 \\
\hline Nevada-3B & 4806 \\
\hline Nevada-5B & 4288 \\
\hline Nevada & 4736 \\
\hline New Hampshire-5A & 10054 \\
\hline New Hampshire-6A & 11570 \\
\hline New Hampshire & 10635 \\
\hline New Jersey-4A & 8546 \\
\hline New Jersey-5A & 8009 \\
\hline New Jersey & 8393 \\
\hline New Mexico-3B & 4954 \\
\hline New Mexico-4B & 3803 \\
\hline New Mexico-5B & 3293 \\
\hline New Mexico & 4015 \\
\hline New York-4A & 6175 \\
\hline New York-5A & 11593 \\
\hline New York-6A & 11543 \\
\hline New York & 9777 \\
\hline North Carolina-3A & 3846 \\
\hline North Carolina-3AWH & 3546 \\
\hline North Carolina-4A & 4189 \\
\hline North Carolina-5A & 6521 \\
\hline North Carolina & 4022 \\
\hline North Dakota-6A & 6946 \\
\hline North Dakota-7A & 6102 \\
\hline North Dakota & 6345 \\
\hline Ohio-4A & 6209 \\
\hline Ohio-5A & 5044 \\
\hline
\end{tabular}


Table 8.9 (contd)

\begin{tabular}{|c|c|}
\hline State - Climate Zone & Life Cycle Cost Savings over the 2009 IECC (\$) \\
\hline Ohio & 5151 \\
\hline Oklahoma-3A & 6025 \\
\hline Oklahoma-4B & 5593 \\
\hline Oklahoma & 6025 \\
\hline Oregon-4C & 3055 \\
\hline Oregon-5B & 6076 \\
\hline Oregon & 3450 \\
\hline Pennsylvania-4A & 7697 \\
\hline Pennsylvania-5A & 8844 \\
\hline Pennsylvania-6A & 10990 \\
\hline Pennsylvania & 8632 \\
\hline Rhode Island-5A & 11011 \\
\hline Rhode Island & 11011 \\
\hline South Carolina-3A & 4690 \\
\hline South Carolina-3AWH & 3842 \\
\hline South Carolina & 4366 \\
\hline SouthDakota-5A & 7634 \\
\hline South Dakota-6A & 6862 \\
\hline South Dakota & 6910 \\
\hline Tennessee-3A & 3865 \\
\hline Tennessee-4A & 4280 \\
\hline Tennessee & 4217 \\
\hline Texas-2AWH & 2505 \\
\hline Texas-2BWH & 2828 \\
\hline Texas-3A & 5485 \\
\hline Texas-3AWH & 5662 \\
\hline Texas-3B & 3886 \\
\hline Texas-4B & 6118 \\
\hline Texas & 3456 \\
\hline Utah-3B & 3789 \\
\hline Utah-5B & 3580 \\
\hline Utah-6B & 2895 \\
\hline Utah & 3479 \\
\hline Vermont-6A & 13699 \\
\hline Vermont & 13699 \\
\hline Virginia-4A & 5255 \\
\hline Virginia & 5255 \\
\hline Washington-4C & 2922 \\
\hline Washington-5B & 5983 \\
\hline Washington-6B & 6999 \\
\hline
\end{tabular}


Table 8.9 (contd)

\begin{tabular}{lc}
\hline State - Climate Zone & Life Cycle Cost Savings over the 2009 IECC (\$) \\
\hline Washington & 3778 \\
West Virginia-4A & 5393 \\
West Virginia-5A & 5126 \\
West Virginia & 5270 \\
Wisconsin-6A & 7738 \\
Wisconsin-7A & 12445 \\
Wisconsin & 8186 \\
Wyoming-5B & 4722 \\
Wyoming-6B & 4475 \\
Wyoming-7B & 5702 \\
Wyoming & 4592 \\
\hline
\end{tabular}

\subsection{Cost-Effectiveness Reports}

National and state IECC cost-effectiveness results from this analysis are published online and are available for download on the energy codes website. ${ }^{1}$

\footnotetext{
${ }^{1}$ http://www.energycodes.gov/development/residential/iecc_analysis.
} 


\subsection{References}

Appalachian State University. 2010. Development and Implementation of an Improved Residential Code for North Carolina. Department of Technology and Energy Center, Boone, North Carolina.

Hammon RW and MP Modera. 1999. Improving the Efficiency of Air Distribution Systems in New California Homes-Updated Report. Stockton, California. Available at ucciee.org/downloads/AirsystemsinCAhomes.Modera.PDF.

Hendron R and C Engebrecht. 2009. Building America Research Benchmark Definition. NREL/TP-55047246, National Renewable Energy Laboratory, Golden, Colorado.

Hendron R and C Engebrecht. 2010. Building America House Simulation Protocols. National Renewable Energy Laboratory, Golden, Colorado.

Klein G. 2012. Cost Estimation for Materials and Installation of Hot Water Pipe Insulation. Affiliated International Management, LLC, Newport, California.

Lutz J, CD Whitehead, A Lekov, G Rosequist, and D Winiarski. 1998. WHAM: "A Simplified Energy Consumption Equation for Water Heaters.” ACEEE Summer Study on Energy Efficiency in Buildings, Asilomar, California.

National Association of Home Builders (NAHB). 2009. Economic Database in Support of ASHRAE 90.2 (Energy Efficient Design of Low-Rise Residential Buildings). Report 3296_051409, NAHB Research Center, Upper Marlboro, Maryland.

RLW Analytics. 2007. Single-family Residential New Construction Characteristcis and Practices Study. Sonoma, California.

RS Means. 2011. 2012 Residential Cost Data. RS Means Company, Kingston, Massachusetts

Taylor T., N Fernandez, and R Lucas. 2012. Methodology for Evaluating Cost-Effectiveness of Residential Energy Code Changes. PNNL-21294, prepared for the U.S. Department of Energy by Pacific Northwest National Laboratory, Richland, Washington.

Uniacke M. 2003. "Pressure-Testing Ductwork.” Journal of Light Construction April 2003.

U.S. Environmental Protection Agency (EPA). 2011. ENERGY STAR Qualified Homes 2011 Savings \& Cost Estimate Summary. Washington, D.C. 


\section{Appendix A}

\section{Building Energy Model Description}




\section{A.1 Single-Family Prototype Modeling Description}

\begin{tabular}{|c|c|c|}
\hline Item & Description & Data Source \\
\hline \multicolumn{3}{|c|}{ General } \\
\hline Vintage & New Construction & \\
\hline Locations & See under the '2.2 Climate Locations' & $\begin{array}{l}\text { Reference: Methodology for } \\
\text { Evaluating Cost-Effectiveness of } \\
\text { Residential Energy Code Changes }\end{array}$ \\
\hline Available fuel types & Natural Gas/Electricity/Fuel Oil & \\
\hline $\begin{array}{l}\text { Building Type (Principal Building } \\
\text { Function) }\end{array}$ & Residential & \\
\hline Building Prototype & Single-family Detached & \\
\hline \multicolumn{3}{|c|}{ Form } \\
\hline Total Floor Area (sq. feet) & $\begin{array}{c}2,400 \\
\left(30^{\prime} \times 40^{\prime} \times 2 \text { stories }\right)\end{array}$ & \\
\hline Building shape & & $\begin{array}{l}\text { Reference: Methodology for } \\
\text { Evaluating Cost-Effectiveness of } \\
\text { Residential Energy Code Changes }\end{array}$ \\
\hline Aspect Ratio & 1.33 & \\
\hline
\end{tabular}




\begin{tabular}{|c|c|c|}
\hline Item & Description & Data Source \\
\hline Number of Floors & 2 & \\
\hline $\begin{array}{l}\text { Window Fraction } \\
\text { (Window-to-Floor Ratio) }\end{array}$ & Average Total: $15.0 \%$ divided equally among all facades & $\begin{array}{l}\text { Reference: Methodology for } \\
\text { Evaluating Cost-Effectiveness of } \\
\text { Residential Energy Code Changes }\end{array}$ \\
\hline Window Locations & All facades & \\
\hline Shading Geometry & none & \\
\hline Orientation & Back of the house faces North (see image) & \\
\hline Thermal Zoning & $\begin{array}{l}\text { The house is divided into three thermal zones: 'living space', 'attic' and 'crawlspace', } \\
\text { 'heated basement', 'unheated basement' when applicable. }\end{array}$ & \\
\hline Floor to ceiling height & 8.5 & \\
\hline \multicolumn{3}{|l|}{ Architecture } \\
\hline \multicolumn{3}{|l|}{ Exterior walls } \\
\hline Construction & $\begin{array}{l}\text { Wood-Frame Walls ( } 2 \times 4 \text { 16" O.C. or } 2 \times 624 " \text { O.C.) } \\
\text { 1" Stucco + Building Paper Felt + Insulating Sheathing (if applicable) }+5 / 8 \text { " Oriented } \\
\text { Strand Board + Wall Insulation + 1/2" Drywall }\end{array}$ & \\
\hline $\begin{array}{l}\text { U-factor }\left(\mathrm{Btu} / \mathrm{h} * \mathrm{ft}^{2} *{ }^{\circ} \mathrm{F}\right) \\
\text { and/or } \\
\quad \mathrm{R} \text {-value }\left(\mathrm{h} * \mathrm{ft}^{2} *{ }^{\circ} \mathrm{F} / \mathrm{Btu}\right)\end{array}$ & $\begin{array}{l}\text { IECC Requirements } \\
\text { Residential; Walls, above grade, Wood Frame }\end{array}$ & IECC \\
\hline Dimensions & $40^{\prime}$ x 8'6" and $30^{\prime}$ x 8'6" & \\
\hline Tilts and orientations & Vertical & \\
\hline \multicolumn{3}{|l|}{ Roof } \\
\hline Construction & Asphalt Shingles & \\
\hline $\begin{array}{l}\mathrm{U} \text {-factor }\left(\mathrm{Btu} / \mathrm{h} * \mathrm{ft}^{2} *{ }^{\circ} \mathrm{F}\right) \\
\text { and/or } \\
\quad \mathrm{R} \text {-value }\left(\mathrm{h} * \mathrm{ft}^{2} *{ }^{\circ} \mathrm{F} / \mathrm{Btu}\right)\end{array}$ & $\begin{array}{l}\text { IECC Requirements } \\
\text { Residential; Ceiling R value }\end{array}$ & IECC \\
\hline
\end{tabular}




\begin{tabular}{|c|c|c|}
\hline Item & Description & Data Source \\
\hline Tilts and orientations & Gabled Roof with a Slope of $4 / 12$ & \\
\hline \multicolumn{3}{|l|}{ Window } \\
\hline Dimensions & based on window fraction, location, floor area and aspect ratio & \\
\hline Glass-Type and frame & Hypothetical window with the exact U-factor and SHGC shown below & \\
\hline U-factor $\left(\mathrm{Btu} / \mathrm{h} * \mathrm{ft}^{2} *{ }^{\circ} \mathrm{F}\right)$ & \multirow{2}{*}{$\begin{array}{l}\text { IECC Requirements } \\
\text { Residential; Glazing }\end{array}$} & \multirow{2}{*}{ IECC } \\
\hline SHGC (all) & & \\
\hline \multicolumn{3}{|l|}{ Skylight } \\
\hline Dimensions & Not Modeled & \\
\hline Glass-Type and frame & \multirow{4}{*}{ NA } & \\
\hline $\mathrm{U}$-factor $\left(\mathrm{Btu} / \mathrm{h} * \mathrm{ft}^{2} *{ }^{\circ} \mathrm{F}\right)$ & & \\
\hline SHGC (all) & & \\
\hline Visible transmittance & & \\
\hline \multicolumn{3}{|l|}{ Foundation } \\
\hline Foundation Type & $\begin{array}{l}\text { Four Foundation Types are Modeled- } \\
\text { i. Slab-on Grade } \\
\text { ii. Vented Crawlspace Depth 2' } \\
\text { iii. Heated Basement - Depth 7' } \\
\text { iv. Unheated Basement- Depth 7' }\end{array}$ & $\begin{array}{l}\text { Reference: Methodology for } \\
\text { Evaluating Cost-Effectiveness of } \\
\text { Residential Energy Code Changes }\end{array}$ \\
\hline Insulation level & IECC Requirements for floors, slabs and basement walls & IECC \\
\hline Dimensions & based on floor area and aspect ratio & \\
\hline Internal Mass & $8 \mathrm{lbs} / \mathrm{ft} 2$ of floor area & IECC 2006 section 404 \\
\hline
\end{tabular}




\begin{tabular}{|c|c|c|}
\hline Item & Description & Data Source \\
\hline Infiltration (ACH) & $\begin{array}{c}2006 \text { IECC: } 8 \text { Air Changes/Hour at } 50 \mathrm{~Pa} \\
\text { 2009 IECC: } 7 \text { Air Changes/Hour at } 50 \mathrm{~Pa} \\
\text { 2012 IECC: } 5 \text { or } 3 \text { Air Changes/Hour at } 50 \text { Pa depending on climate zone }\end{array}$ & \\
\hline \multicolumn{3}{|c|}{ HVAC } \\
\hline System Type & & \\
\hline Heating type & $\begin{array}{l}\text { Four Heating System Types are Modeled- } \\
\text { i. Gas Furnace } \\
\text { ii. Oil Furnace } \\
\text { iii. Electric Furnace } \\
\text { iv. Heat Pump }\end{array}$ & \multirow[t]{2}{*}{$\begin{array}{l}\text { Reference: Methodology for } \\
\text { Evaluating Cost-Effectiveness of } \\
\text { Residential Energy Code Change }\end{array}$} \\
\hline Cooling type & Central DX Air-Conditioner/Heat Pump & \\
\hline \multicolumn{3}{|l|}{ HVAC Sizing } \\
\hline Cooling & autosized to design day & \\
\hline Heating & autosized to design day & \\
\hline \multicolumn{3}{|l|}{ HVAC Efficiency } \\
\hline Air Conditioning & SEER 13 & Federal minimum efficiency \\
\hline Heating & AFUE 78\% / HSPF 7.7 & Federal minimum efficiency \\
\hline \multicolumn{3}{|l|}{ HVAC Control } \\
\hline Thermostat Setpoint & $75^{\circ} \mathrm{F}$ Cooling $/ 72^{\circ} \mathrm{F}$ Heating & \\
\hline Thermostat Setback & No setback & \\
\hline Supply air temperature & Maximum $110 \mathrm{~F}$, Minimum $52 \mathrm{~F}$ & \\
\hline
\end{tabular}




\begin{tabular}{|c|c|c|}
\hline Item & Description & Data Source \\
\hline Ventilation & 60 CFM Outdoor Air; Continuous Supply & 2012 IRC \\
\hline \multicolumn{3}{|l|}{ Supply Fan } \\
\hline Fan schedules & See Appendix A.4 & \\
\hline Supply Fan Total Efficiency (\%) & Fan Efficiency 58\%; Motor efficiency 65\% (PSC motor) & $\begin{array}{l}\text { Residential Furnaces aand Centralized } \\
\text { Air Condtioners and Heat Pumps } \\
\text { Direct Final Rule Technical Support } \\
\text { Document. }\end{array}$ \\
\hline Supply Fan Pressure Drop & $1.6 "$ w.g. & \\
\hline \multicolumn{3}{|l|}{$\begin{array}{l}\text { Domestic Hot } \\
\text { Water }\end{array}$} \\
\hline DHW type & Individual Residential Water Heater with Storage Tank & \\
\hline Fuel type & Natural Gas/Electricity & \\
\hline Thermal efficiency $(\%)$ & $\begin{array}{l}E F=0.59 \text { for Gas-fired Water Heaters } \\
E F=0.917 \text { for Electric Water Heaters }\end{array}$ & Federal minimum efficiency \\
\hline Tank Volume (gal) & $\begin{array}{l}40 \text { for Gas-fired Water Heaters } \\
52 \text { for Electric Water Heaters }\end{array}$ & \multirow{3}{*}{$\begin{array}{l}\text { Reference: } \\
\text { Building America Research } \\
\text { Benchmark }\end{array}$} \\
\hline Water temperature set-point & $120 \mathrm{~F}$ & \\
\hline Schedules & See Appendix A.4 & \\
\hline \multicolumn{3}{|l|}{ Internal Loads \& Schedules } \\
\hline \multicolumn{3}{|l|}{ Lighting } \\
\hline $\begin{array}{l}\text { Average interior power density } \\
\left(\mathrm{W} / \mathrm{ft}^{2}\right)\end{array}$ & $\begin{array}{l}\text { Living space: Lighting Power Density is } 0.68 \mathrm{~W} / \mathrm{sq} . \mathrm{ft} \text { for the } 2006 \text { IECC } \\
\text { - See '4.4 Lighting' for the detailed calculations }\end{array}$ & $\begin{array}{l}\text { Reference: } \\
2010 \text { Building America House } \\
\text { Simulation Prototcols }\end{array}$ \\
\hline
\end{tabular}

\footnotetext{
${ }^{1}$ Residential Furnaces and Central Air Conditioners and Heat Pumps Direct Final Rule Technical Support Document - Chapter 7 'Energy Use Characterization' http://www1.eere.energy.gov/buildings/appliance_standards/residential/pdfs/hvac_ch_07_energy-use_2011-04-25.pdf
} 


\begin{tabular}{|c|c|c|}
\hline Item & Description & Data Source \\
\hline Interior Lighting Schedule & See Appendix A.4 & \\
\hline \multicolumn{3}{|l|}{ Internal Gains } \\
\hline Load (Btu/day) & $\begin{array}{l}17,900+23.8 \times \mathrm{CFA}+4104 \times \mathrm{Nbr} \\
\text { See under '4.3 Internal Gains' for the detailed calculations }\end{array}$ & \multirow[t]{2}{*}{$\begin{array}{l}\text { Reference: } \\
\text { IECC } 2006 \text { and Building America } \\
\text { Research Benchmark }\end{array}$} \\
\hline Internal gains Schedule(s) & See Appendix A.4 & \\
\hline \multicolumn{3}{|l|}{ Occupancy } \\
\hline Number of people & 3 & \\
\hline Occupancy Schedule & See Appendix A.4 & \\
\hline \multicolumn{3}{|l|}{ Exterior Lighting } \\
\hline Annual Energy (kWh) & 348 for the 2006 IECC & \multirow[b]{2}{*}{$\begin{array}{l}\text { Reference: } \\
\text { 2010 Building America House } \\
\text { Simulation Prototcols }\end{array}$} \\
\hline Exterior lighting Schedule & See Appendix A.4 & \\
\hline \multicolumn{3}{|l|}{ Garage Lighting } \\
\hline Annual Energy (kWh) & 40 for the 2006 IECC & \multirow{2}{*}{$\begin{array}{l}\text { Reference: } \\
\text { 2010 Building America House } \\
\text { Simulation Prototcols }\end{array}$} \\
\hline Garage Lighting Schedule & See Appendix A.4 & \\
\hline
\end{tabular}




\section{A.2 Multifamily Prototype Modeling Description}

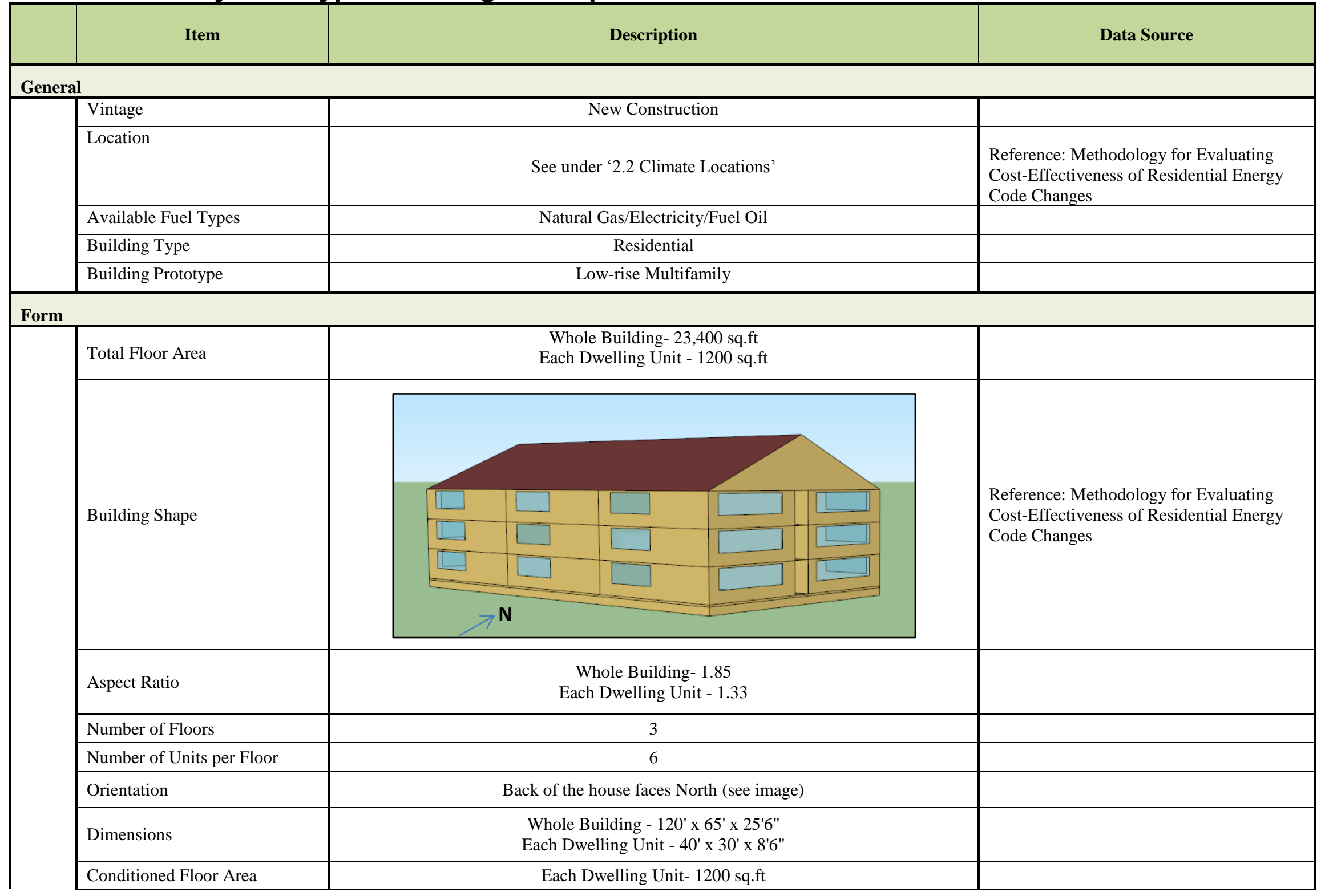




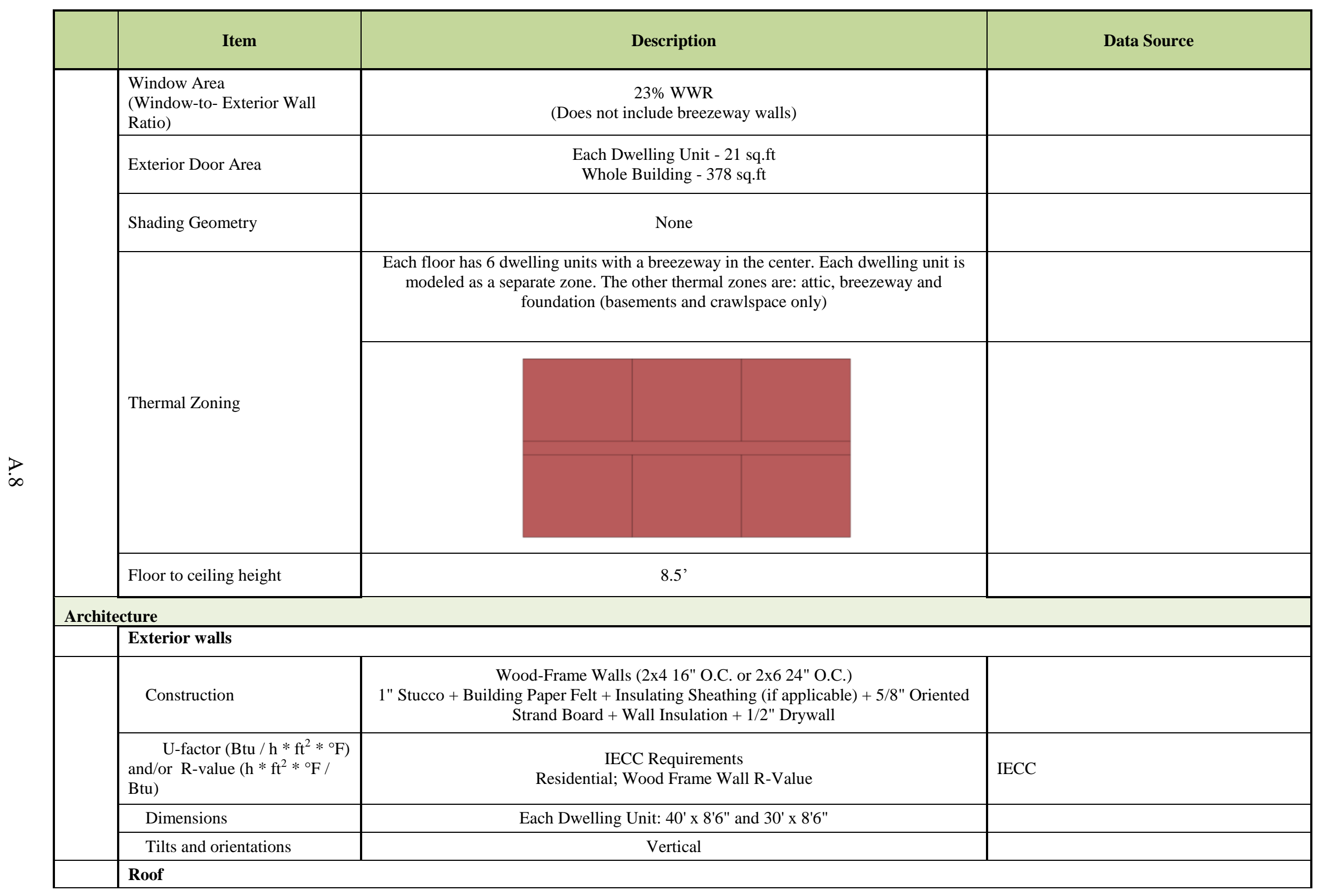




\begin{tabular}{|c|c|c|}
\hline Item & Description & Data Source \\
\hline Construction & Asphalt Shingles & \\
\hline $\begin{array}{l}\text { U-factor }\left(\mathrm{Btu} / \mathrm{h} * \mathrm{ft}^{2} *{ }^{\circ} \mathrm{F}\right) \\
\text { and/or } \\
\quad \text { R-value }\left(\mathrm{h} * \mathrm{ft}^{2} *{ }^{\circ} \mathrm{F} / \mathrm{Btu}\right)\end{array}$ & $\begin{array}{l}\text { IECC Requirements } \\
\text { Residential; Ceiling R value }\end{array}$ & IECC \\
\hline Tilts and orientations & Gabled Roof with a Slope of $4 / 12$ & \\
\hline \multicolumn{3}{|l|}{ Window } \\
\hline Dimensions & based on window fraction, location, glazing sill height, floor area and aspect ratio & \\
\hline Glass-Type and frame & Hypothetical window with the exact U-factor and SHGC shown below. & \\
\hline $\mathrm{U}$-factor $\left(\mathrm{Btu} / \mathrm{h} * \mathrm{ft}^{2} *{ }^{\circ} \mathrm{F}\right)$ & \multirow{2}{*}{$\begin{array}{c}\text { IECC Requirements } \\
\text { Fenestration U-Factor \& SHGC }\end{array}$} & \\
\hline SHGC (all) & & \\
\hline \multicolumn{3}{|l|}{ Skylight } \\
\hline Dimensions & Not Modeled & \\
\hline Glass-Type and frame & \multirow{4}{*}{ NA } & \\
\hline $\mathrm{U}$-factor $\left(\mathrm{Btu} / \mathrm{h} * \mathrm{ft}^{2} *{ }^{\circ} \mathrm{F}\right)$ & & \\
\hline SHGC (all) & & \\
\hline Visible transmittance & & \\
\hline \multicolumn{2}{|l|}{ Foundation } & \\
\hline Foundation Type & $\begin{array}{l}\text { Four Foundation Types are Modeled- } \\
\text { i. Slab-on Grade } \\
\text { ii. Vented Crawlspace Depth 2' } \\
\text { iii. Heated Basement - Depth 7' } \\
\text { iv. Unheated Basement- Depth 7' }\end{array}$ & $\begin{array}{l}\text { Reference: Methodology for Evaluating } \\
\text { Cost-Effectiveness of Residential Energy } \\
\text { Code Changes }\end{array}$ \\
\hline Insulation level & IECC Requirements for floors, slabs and basement walls & \\
\hline Dimensions & based on floor area and aspect ratio & \\
\hline Internal Mass & $8 \mathrm{lbs} / \mathrm{ft} 2$ of floor area & IECC 2006 section 404 \\
\hline
\end{tabular}




\begin{tabular}{|c|c|c|}
\hline Item & Description & Data Source \\
\hline Infiltration (ACH) & $\begin{array}{c}\text { 2006 IECC: } 8 \text { Air Changes/Hour at } 50 \mathrm{~Pa} \\
\text { 2009 IECC: } 7 \text { Air Changes/Hour at } 50 \mathrm{~Pa} \\
\text { 2012 IECC: } 5 \text { or } 3 \text { Air Changes/Hour at } 50 \text { Pa depending on climate zone }\end{array}$ & \\
\hline \multicolumn{3}{|c|}{ HVAC } \\
\hline \multicolumn{3}{|l|}{ System Type } \\
\hline Heating type & $\begin{array}{l}\text { Four Heating System Types are Modeled- } \\
\text { i. Gas Furnace } \\
\text { ii. Oil Furnace } \\
\text { iii. Electric Furnace } \\
\text { iv. Heat Pump }\end{array}$ & \\
\hline Cooling type & Central DX Air-Conditioner/Heat Pump (1 per unit) & \\
\hline \multicolumn{3}{|l|}{ HVAC Sizing } \\
\hline Cooling & autosized to design day & \\
\hline Heating & autosized to design day & \\
\hline \multicolumn{3}{|l|}{ HVAC Efficiency } \\
\hline Air Conditioning & SEER 13 & $\begin{array}{l}\text { Federal Minimum Equipment Efficiency } \\
\text { for Air Conditioners and Condensing Units }\end{array}$ \\
\hline Heating & AFUE $78 \%$ / HSPF 7.7 & Federal Minimum Equipment Efficiency \\
\hline \multicolumn{3}{|l|}{ HVAC Control } \\
\hline Thermostat Setpoint & $75^{\circ} \mathrm{F}$ Cooling $/ 72^{\circ} \mathrm{F}$ Heating & \\
\hline Thermostat Setback & No setback & \\
\hline Supply air temperature & Maximum $110 \mathrm{~F}$, Minimum $52 \mathrm{~F}$ & \\
\hline Ventilation & 45 CFM Outdoor Air per dwelling unit; Continuous Supply & 2012 International Mechanical Code (IMC) \\
\hline \multicolumn{3}{|l|}{ Supply Fan } \\
\hline Fan schedules & See Appendix A.4 & \\
\hline
\end{tabular}




\begin{tabular}{|c|c|c|}
\hline Item & Description & Data Source \\
\hline $\begin{array}{l}\text { Supply Fan Total Efficiency } \\
(\%)\end{array}$ & Fan efficiency 58\%; Motor efficiency 65\% (PSC motor) & $\begin{array}{l}\text { Residential Furnaces and Centralized Air } \\
\text { Conditioners and Heat Pumps Direct Final } \\
\text { Rule Technical Support Document }^{1}\end{array}$ \\
\hline Supply Fan Pressure Drop & $1.6 "$ w.g. & \\
\hline \multicolumn{3}{|l|}{ Service Water Heating } \\
\hline SWH type & Individual Residential Water Heater with Storage Tank & \\
\hline Fuel type & Natural Gas / Electricity & \\
\hline Thermal efficiency (\%) & $\begin{array}{l}E F=0.59 \text { for Gas-fired Water Heaters } \\
E F=0.917 \text { for Electric Water Heaters }\end{array}$ & Federal Minimum Equipment Efficiency \\
\hline Tank Volume (gal) & 40 & \\
\hline Water temperature set-point & $120 \mathrm{~F}$ & \\
\hline Schedules & See Appendix A.4 & \\
\hline \multicolumn{3}{|l|}{ Internal Loads \& Schedules } \\
\hline Lighting & & \\
\hline $\begin{array}{l}\text { Average power density } \\
\left(\mathrm{W} / \mathrm{ft}^{2}\right)\end{array}$ & $\begin{array}{l}\text { Dwelling unit units: Lighting Power Density is } 0.82 \mathrm{~W} / \mathrm{sq} . \mathrm{ft} \text { (For interior lighting) for } \\
\text { the } 2006 \text { IECC } \\
\text { See ' } 4.4 \text { Lighting' for the detailed calculations }\end{array}$ & $\begin{array}{l}2010 \text { Building America House Simulation } \\
\text { Prototcols }\end{array}$ \\
\hline Interior Lighting Schedule & See Appendix A.4 & \\
\hline Internal Gains & & \\
\hline $\begin{array}{l}\text { Internal Gains (Btu/day per } \\
\text { Dwelling Unit) }\end{array}$ & $\begin{array}{c}17,900+23.8 \times \mathrm{CFA}+4104 \times \mathrm{N}_{\mathrm{br}} \\
\text { See '4.3 Internal Gains' for the detailed calculations }\end{array}$ & \\
\hline
\end{tabular}

\footnotetext{
${ }^{1}$ Residential Furnaces and Centralized Air Conditioners and Heat Pumps Direct Final Rule Technical Support Document: Chapter 7 'Energy Use Characterization' Residential Furnaces and Centralized Air Conditioners and Heat Pumps Direct Final Rule Technical Support Document
} 


\begin{tabular}{|c|c|c|c|}
\hline & Item & Description & Data Source \\
\hline & Internal Gains Schedule(s) & See under Appendix A.4 & \\
\hline & Occupancy & & \\
\hline & Average people & 2 & \\
\hline & Occupancy Schedule & See Appendix A.4 & \\
\hline \multicolumn{4}{|l|}{ Misc. } \\
\hline & Exterior Lighting & & \\
\hline & Annual energy $(\mathrm{kWh})$ & 174 for the 2006 IECC & \\
\hline & Exterior Lighting Schedule & See Appendix A.4 & \\
\hline & Garage Lighting & & \\
\hline & Annual energy (kWh) & 24 for the 2006 IECC & \\
\hline & Garage Lighting Schedule & See Appendix A.4 & \\
\hline
\end{tabular}




\section{A.3 Internal Gains Assumptions}

A.3.1 Total Internal Gains for the single-family prototype for the 2006, 2009 and 2012 IECC

\begin{tabular}{|c|c|c|c|c|c|c|c|c|}
\hline \multirow[t]{2}{*}{ Appliance } & \multirow[t]{2}{*}{ Power } & \multirow{2}{*}{$\begin{array}{c}\text { Total } \\
\text { Electricity } \\
(\mathbf{k W h} / \mathbf{y r})\end{array}$} & \multirow[t]{2}{*}{$\begin{array}{l}\text { Fraction } \\
\text { Sensible }\end{array}$} & \multirow[t]{2}{*}{$\begin{array}{c}\text { Fraction } \\
\text { Latent }\end{array}$} & \multirow{2}{*}{$\begin{array}{c}\text { Fraction of } \\
\text { electricity } \\
\text { use not } \\
\text { turned into } \\
\text { heat } \\
\end{array}$} & \multicolumn{3}{|c|}{$\begin{array}{c}\text { Internal Heat Gains } \\
(\mathrm{kWh} / \mathrm{yr})\end{array}$} \\
\hline & & & & & & 2006 IECC & 2009 IECC & 2012 IECC \\
\hline Refrigerator & $91.09 \mathrm{~W}$ & 668.90 & 1.00 & 0.00 & 0.00 & 669 & 669 & 669 \\
\hline Clothes Washer & $29.6 \mathrm{~W}$ & 109.16 & 0.80 & 0.00 & 0.20 & 87 & 87 & 87 \\
\hline Clothes Dryer & $222.11 \mathrm{~W}$ & 868.15 & 0.15 & 0.05 & 0.80 & 174 & 174 & 174 \\
\hline Dishwasher & $68.33 \mathrm{~W}$ & 214.16 & 0.60 & 0.15 & 0.25 & 161 & 161 & 161 \\
\hline Range & $248.97 \mathrm{~W}$ & 604.90 & 0.40 & 0.30 & 0.30 & 423 & 423 & 423 \\
\hline Misc. Plug Load & $0.228 \mathrm{~W} / \mathrm{sq} . \mathrm{ft}$ & 3238.13 & 0.69 & 0.06 & 0.25 & 2429 & 2429 & 2429 \\
\hline Miscellaneous Electric Loads & $182.5 \mathrm{~W}$ & 1598.00 & 0.69 & 0.06 & 0.25 & 1199 & 1199 & 1199 \\
\hline IECC adjustment factor & $0.0275 \mathrm{~W} / \mathrm{sq} . \mathrm{ft}$ & 390.56 & 0.69 & 0.06 & 0.25 & 293 & 293 & 293 \\
\hline Lighting & & & 1.00 & 0.00 & 0.00 & 1635 & 1345 & 1164 \\
\hline Occupants & 3 Occupants & & & & & 2123 & 2123 & 2123 \\
\hline \multirow[t]{3}{*}{ Total } & & & & & kWh/yr & 9192 & 8902 & 8721 \\
\hline & & & & & kBtu/yr & 31362 & 30373 & 29755 \\
\hline & & & & & Btu/day & 85924 & 83213 & 81522 \\
\hline
\end{tabular}


A.3.2 Total Internal Gains for the multifamily prototype for the 2006, 2009 and 2012 IECC (per dwelling unit)

\begin{tabular}{|c|c|c|c|c|c|c|c|c|}
\hline \multirow[t]{2}{*}{ Appliance } & \multirow[t]{2}{*}{ Power } & \multirow{2}{*}{$\begin{array}{c}\text { Total } \\
\text { Electricity } \\
(\mathbf{k W h} / \mathbf{y r})\end{array}$} & \multirow[t]{2}{*}{$\begin{array}{l}\text { Fraction } \\
\text { Sensible }\end{array}$} & \multirow[t]{2}{*}{$\begin{array}{c}\text { Fraction } \\
\text { Latent }\end{array}$} & \multirow{2}{*}{$\begin{array}{l}\text { Fraction of } \\
\text { electricity } \\
\text { use not } \\
\text { turned into } \\
\text { heat } \\
\end{array}$} & \multicolumn{3}{|c|}{$\begin{array}{c}\text { Internal Heat Gains } \\
(\mathrm{kWh} / \mathrm{yr})\end{array}$} \\
\hline & & & & & & 2006 IECC & 2009 IECC & 2012 IECC \\
\hline Refrigerator & $91.09 \mathrm{~W}$ & 668.90 & 1.00 & 0.00 & 0 & 669 & 669 & 669 \\
\hline Clothes Washer & $29.6 \mathrm{~W}$ & 109.16 & 0.80 & 0.00 & 0.2 & 87 & 87 & 87 \\
\hline Clothes Dryer & $222.11 \mathrm{~W}$ & 868.15 & 0.15 & 0.05 & 0.8 & 174 & 174 & 174 \\
\hline Dishwasher & $68.33 \mathrm{~W}$ & 214.16 & 0.60 & 0.15 & 0.25 & 161 & 161 & 161 \\
\hline Range & $248.97 \mathrm{~W}$ & 604.00 & 0.40 & 0.30 & 0.3 & 423 & 423 & 423 \\
\hline Misc. Plug Load & $0.228 \mathrm{~W} / \mathrm{sq} . \mathrm{ft}$ & 1619.00 & 0.69 & 0.06 & 0.25 & 1214 & 1214 & 1214 \\
\hline Miscellaneous Electric Loads & $121.88 \mathrm{~W}$ & 1067.00 & 0.69 & 0.06 & 0.25 & 800 & 800 & 800 \\
\hline IECC adjustment factor & $0.0275 \mathrm{~W} / \mathrm{sq} . \mathrm{ft}$ & 195.28 & 0.69 & 0.06 & 0.25 & 146 & 146 & 146 \\
\hline Lighting & & & 1.00 & 0.00 & 0 & 493 & 405 & 351 \\
\hline Occupants & 2 Occupants & & & & & 1416 & 1416 & 1416 \\
\hline Total & & & & & kWh/yr & 5582 & 5495 & 5440 \\
\hline & & & & & kBtu/yr & 19046 & 18748 & 18562 \\
\hline & & & & & Btu/Day & 52181 & 51364 & 50855 \\
\hline
\end{tabular}




\section{A.4 Schedules}

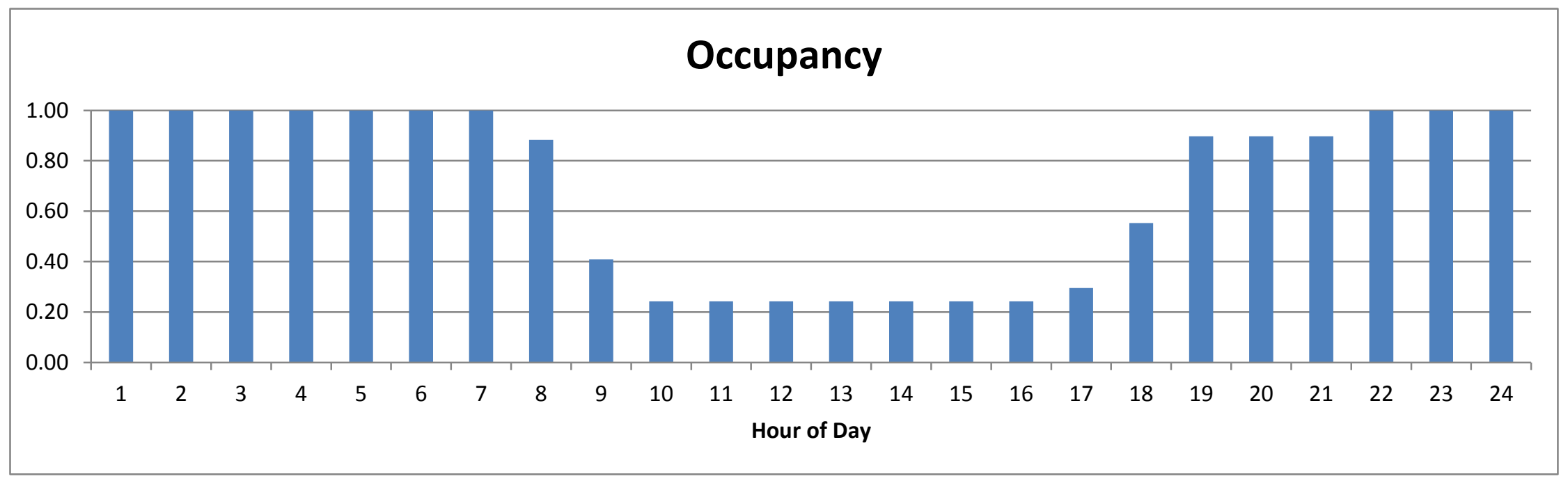

$\stackrel{p}{u}$

\section{HVAC}

Cooling Heating Fan (On/Off)

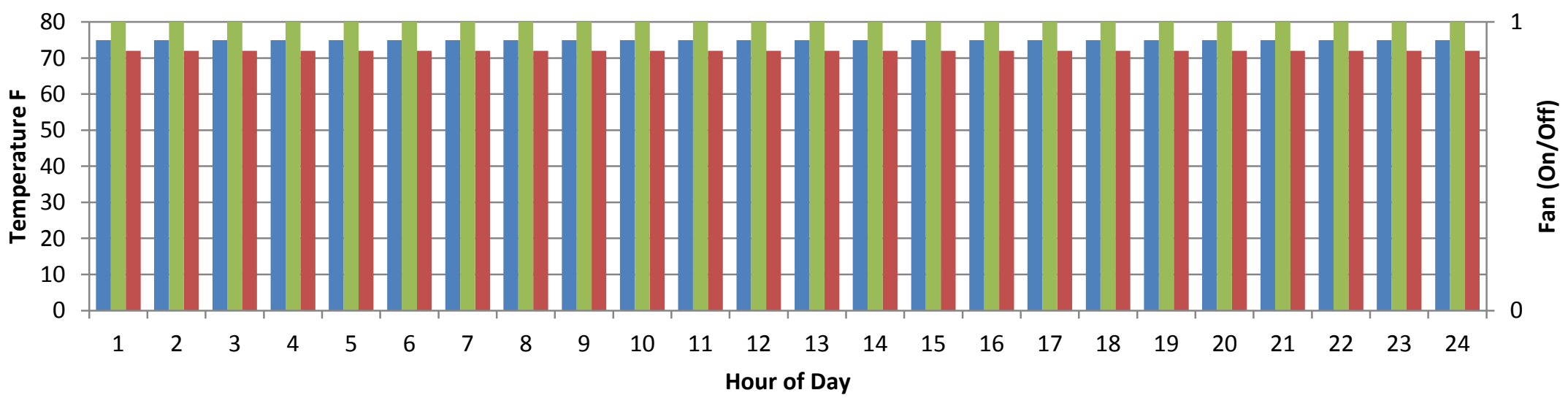



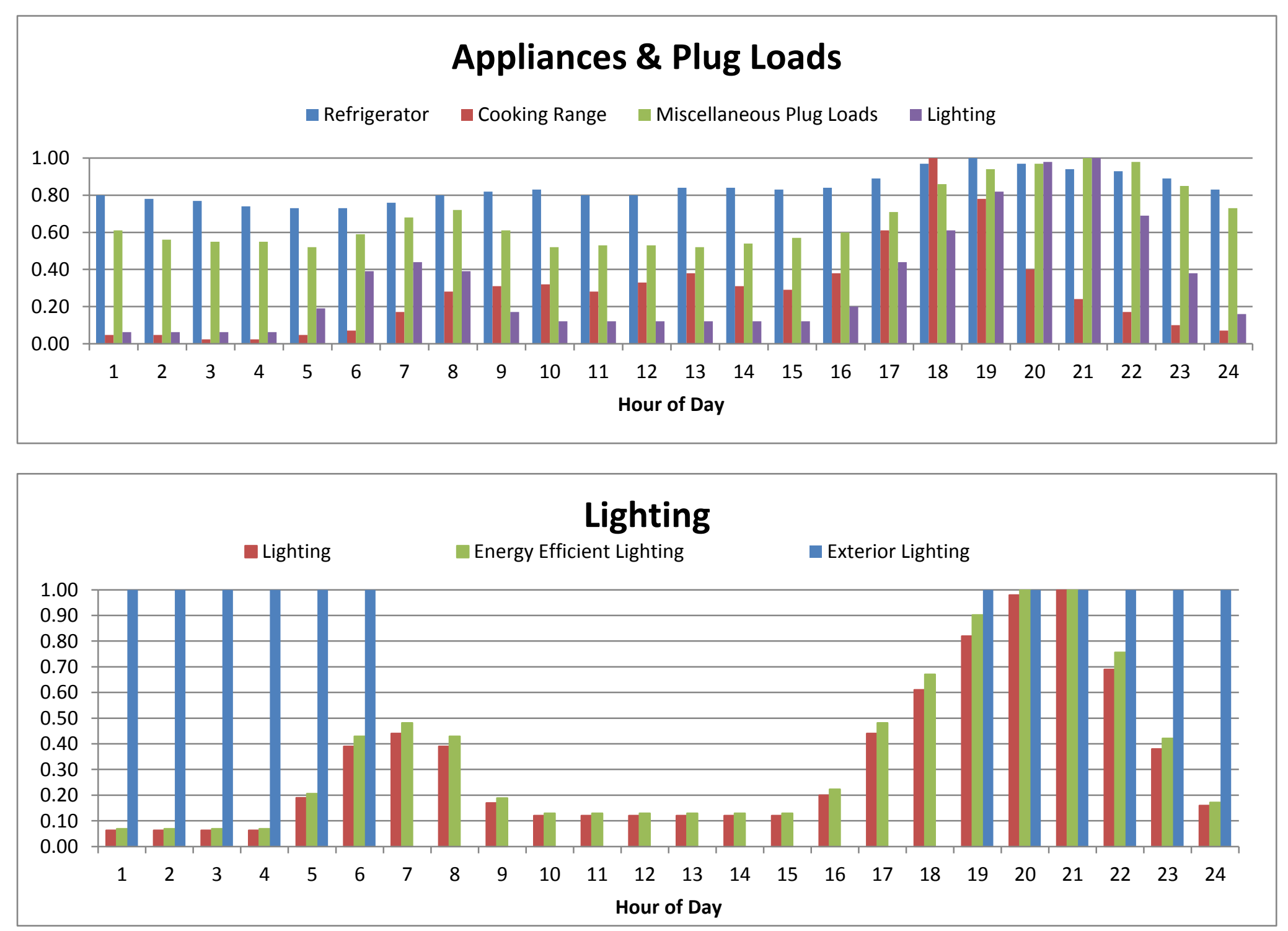


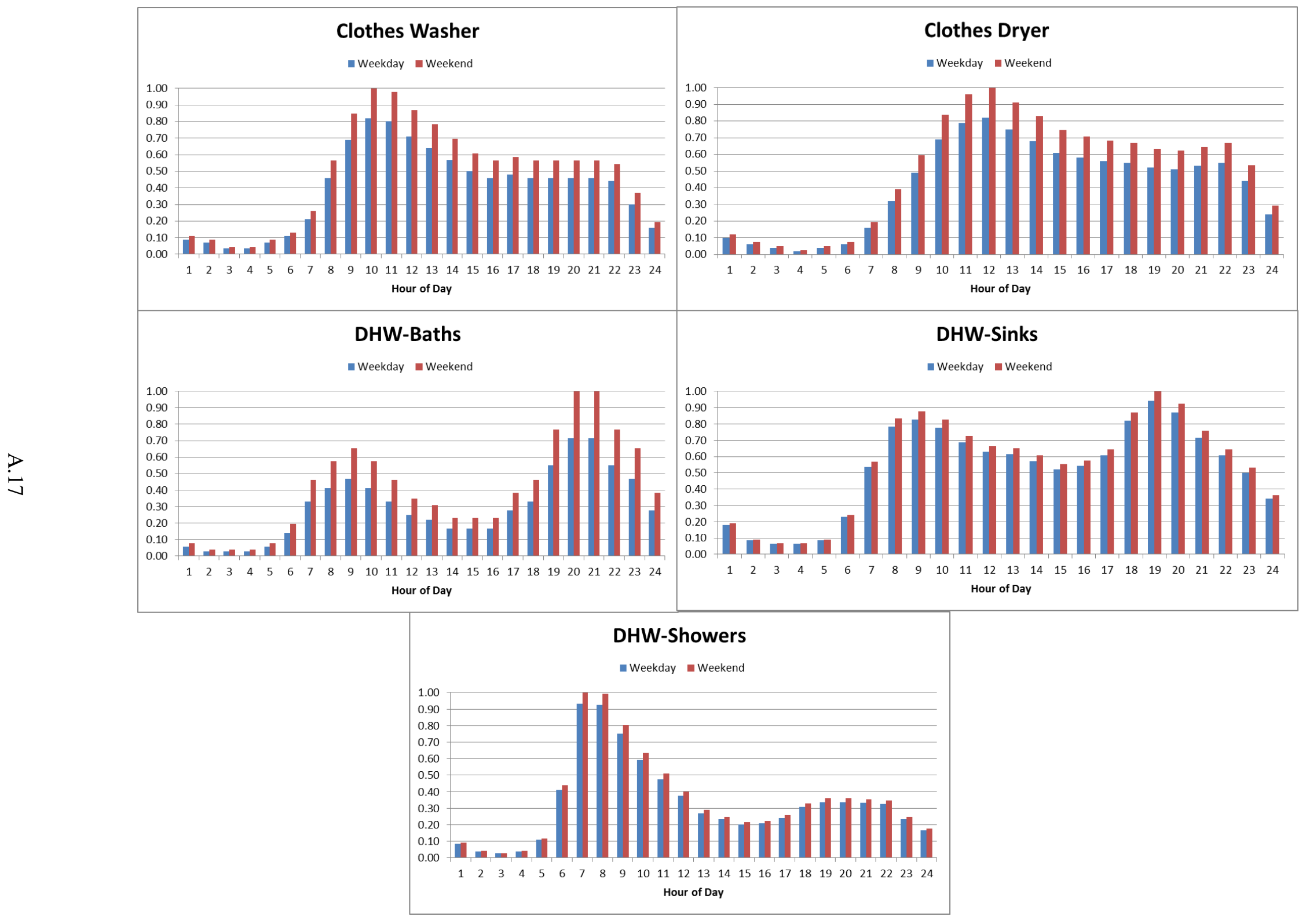




\section{Appendix B}

Major Prescriptive Code Requirements for the 2006 IECC, the 2009 IECC, and the 2012 IECC 
Table B.1.

\begin{tabular}{|c|c|c|c|c|c|c|c|c|c|c|c|c|}
\hline \multirow{3}{*}{$\begin{array}{l}\text { Climate } \\
\text { Zone }\end{array}$} & \multirow[b]{3}{*}{ IECC } & \multicolumn{11}{|c|}{ Components } \\
\hline & & \multirow{2}{*}{$\begin{array}{l}\text { Ceiling } \\
\text { (R-value) }\end{array}$} & \multirow{2}{*}{$\begin{array}{l}\text { Skylight } \\
\text { (U-factor) }\end{array}$} & \multicolumn{2}{|c|}{$\begin{array}{l}\text { Fenestration (Windows } \\
\text { and Doors) }\end{array}$} & \multirow{2}{*}{$\begin{array}{c}\text { Wood } \\
\text { Frame } \\
\text { Wall } \\
\text { (R-value) }\end{array}$} & \multirow{2}{*}{$\begin{array}{c}\text { Mass } \\
\text { Wall }^{(a)} \\
\text { (R-value) }\end{array}$} & \multirow{2}{*}{$\begin{array}{c}\text { Floor } \\
\text { (R-value) }\end{array}$} & \multirow{2}{*}{$\begin{array}{l}\text { Basement } \\
\text { Wall }^{(\mathrm{b})} \\
\text { (R-value) }^{\text {R-valu }}\end{array}$} & \multirow{2}{*}{$\begin{array}{l}\text { Tested Max } \\
\text { Air Leakage } \\
\text { Rate } \\
\text { (air changes } \\
\text { per hour) }\end{array}$} & \multirow{2}{*}{$\begin{array}{c}\text { Slab }^{(\mathrm{c})} \\
\text { (R-value } \\
\text { and depth) }\end{array}$} & \multirow{2}{*}{$\begin{array}{c}\text { Crawl } \\
\text { Space }^{(b)} \\
\text { (R-value) }\end{array}$} \\
\hline & & & & U-factor & SHGC & & & & & & & \\
\hline \multirow{3}{*}{1} & 2006 & & & & 0.4 & & & & & NR & & \\
\hline & 2009 & 30 & 0.75 & NR & 0.3 & 13 & $3 / 4$ & 13 & NR & NR & NR & NR \\
\hline & 2012 & & & & 0.25 & & & & & 5 & & \\
\hline \multirow{3}{*}{2} & 2006 & 30 & 0.75 & 0.75 & 0.4 & & & & & NR & & \\
\hline & 2009 & 30 & 0.75 & 0.65 & 0.3 & 13 & $4 / 6$ & 13 & NR & NR & NR & NR \\
\hline & 2012 & 38 & 0.65 & 0.4 & 0.25 & & & & & 5 & & \\
\hline \multirow{3}{*}{3} & 2006 & 30 & 0.65 & 0.65 & 0.4 & 13 & $5 / 8$ & & 0 & NR & & \\
\hline & 2009 & 30 & 0.65 & 0.5 & 0.3 & 13 & $5 / 8$ & 19 & $5 / 13^{(\mathrm{d})}$ & NR & NR & $5 / 13$ \\
\hline & 2012 & 38 & 0.55 & 0.35 & 0.25 & 20 & $8 / 13$ & & $5 / 13^{(\mathrm{d})}$ & 3 & & \\
\hline \multirow{3}{*}{4} & 2006 & 38 & 0.6 & 0.4 & \multirow{2}{*}{ NR } & 13 & $5 / 13$ & & $10 / 13$ & NR & & $10 / 13$ \\
\hline & 2009 & 38 & 0.6 & 0.35 & & 13 & $5 / 10$ & 19 & $10 / 13$ & NR & $10,2 \mathrm{ft}$ & $10 / 13$ \\
\hline & 2012 & 49 & 0.55 & 0.35 & 0.4 & 20 & $8 / 13$ & & $10 / 13$ & 3 & & $10 / 13$ \\
\hline \multirow{3}{*}{5} & 2006 & 38 & 0.6 & 0.35 & & 19 & $13 / 19$ & & $10 / 13$ & NR & & $10 / 13$ \\
\hline & 2009 & 38 & 0.6 & 0.35 & NR & 20 & $13 / 17$ & 30 & $10 / 13$ & NR & $10,2 \mathrm{ft}$ & $10 / 13$ \\
\hline & 2012 & 49 & 0.55 & 0.32 & & 20 & $15 / 19$ & & $15 / 19$ & 3 & & $15 / 19$ \\
\hline \multirow{3}{*}{6} & 2006 & & 0.6 & 0.35 & & 19 & $10 / 13$ & & $10 / 13$ & NR & & $10 / 13$ \\
\hline & 2009 & 49 & 0.6 & 0.35 & NR & 20 & $15 / 19$ & 30 & $15 / 19$ & NR & $10,4 \mathrm{ft}$ & $10 / 13$ \\
\hline & 2012 & & 0.55 & 0.32 & & $20+5$ & $15 / 19$ & & $15 / 19$ & 3 & & $15 / 19$ \\
\hline \multirow{3}{*}{7 and 8} & 2006 & & 0.6 & 0.35 & & 21 & & 30 & $10 / 13$ & NR & & $10 / 13$ \\
\hline & 2009 & 49 & 0.6 & 0.35 & NR & 21 & $19 / 21$ & 38 & $15 / 19$ & NR & $10,4 \mathrm{ft}$ & $10 / 13$ \\
\hline & 2012 & & 0.55 & 0.32 & & $20+5$ & & 38 & $15 / 19$ & 3 & & $15 / 19$ \\
\hline
\end{tabular}

(a) The second number applies when more than half the insulation is on the interior side of the high mass material in the wall.

(b) The first number is for continuous insulation (e.g., a board or blanket directly on the foundation wall) and the second number is for cavity insulation (i.e., if there is a furred-out wall built against the foundation wall). Only one of these two has to be met.

(c) The first number is R-value. The second value refers to the vertical depth of the insulation around the perimeter.

(d) Basement wall insulation is not required in the warm-humid region of Zone 3 in the southeastern United States.

IECC = International Energy Conservation Code.

$\mathrm{NR} \quad=$ Not required.

SHGC $=$ Solar heat gain coefficient. 


\section{Appendix C}

\section{Custom State Requirements and Analyses}




\section{Appendix C}

\section{Custom State Requirements and Analyses}

\section{C.1 Introduction}

Not at all states adopt the International Energy Conservation Code (IECC) without any modifications. Some states adopt modified versions of the IECC. Pacific Northwest National Laboratory conducted customized state analyses for the District of Columbia, Georgia, Michigan, Minnesota, Montana, Oklahoma, Virginia, Vermont, and Wisconsin to account for changes that these states made to the IECC in their existing code. This section describes the customizations analyzed for each state. The EnergyPlus models and output files and the state cost-effectiveness reports for all the above states are available for download on the energy codes website. ${ }^{1,2}$

\section{C.2 District of Columbia}

The District of Columbia Energy Conservation Code is an amended version of the 2009 IECC with the following changes:

- The DC Energy Conservation Code requires R-18 above-grade wall insulation. The DC Energy Conservation Code requires R-49 ceiling insulation, which is more stringent than the 2012 IECC ceiling insulation requirements.

- The DC Energy Conservation Code requires R-2 hot water piping insulation.

\section{C.3 Georgia}

Georgia has three climate zones (climate zones 2, 3, and 4) as defined by the IECC. The Georgia State Code is an amended version of the 2009 IECC. This analysis assesses the cost effectiveness of the 2012 IECC over the Georgia state energy code. Table C.1 below summarizes prescriptive requirements of the Georgia code that contain differences to the 2009 IECC.

Table C.1. Residential Prescriptive Code Requirements for the State of Georgia

\begin{tabular}{cccc}
\hline Climate Zone & $\begin{array}{c}\text { Fenestration U-Factor } \\
\left(\text { Btu/hr- } \mathrm{ft}^{2}-\mathrm{F}\right)\end{array}$ & Fenestration SHGC & $\begin{array}{c}\text { Slab Insulation R-value and } \\
\text { Insulation Depth }\end{array}$ \\
\hline 2 & 0.5 & 0.3 & 0 \\
3 & 0.5 & 0.3 & 0 \\
4 & 0.35 & 0.3 & 0 \\
\hline
\end{tabular}

\footnotetext{
${ }^{1}$ EnergyPlus models and output files - http://www.energycodes.gov/development/residential/iecc_models.

${ }^{2}$ State Cost-effectiveness Reports - http://www.energycodes.gov/development/residential/iecc_analysis.
} 
Additionally, the Georgia code does not explicitly mention the exception for basement wall insulation in warm-humid climates. Thus, the analysis assumes that basement wall insulation is required by the state code in the representative warm-humid location of Macon. Georgia also does not allow the use of electric resistance as the primary heating source. To address this prohibition, electric resistance heating is not analyzed for Georgia and the weights for electric resistance heat are reassigned proportionally to natural gas heating and heat pumps during the aggregation process.

\section{C.4 Michigan}

Michigan has three climate zones (climate zones 5, 6, and 7) as defined by the IECC. The Michigan Uniform Energy Code is based on the 2009 IECC but does not require duct pressure testing. This analysis assesses the cost effectiveness of the 2012 IECC over the Michigan state energy code by accounting for the savings and incremental costs for duct sealing requirements in 2012 IECC.

\section{C.5 Minnesota}

Minnesota has two climate zones (climate zones 6 and 7) as defined by the IECC. The Minnesota State code is similar to the 2006 IECC but it requires R-38 ceiling insulation in climate zone 6 and R-44 in climate zone 7. It also requires R-19 above grade wall insulation in climate zone 7 . The 2006 IECC has more stringent ceiling and above grade wall insulation requirements than the Minnesota state code. This analysis assesses the cost effectiveness of the 2009 and 2012 IECC over the Minnesota state code.

There is some evidence that the typical envelope leakage rates achieved by builders in Minnesota are lower than the assumed 8 50-Pa pressure differential (ACH50) for the 2006 IECC. A proposed code change (RE-12) to the 1322 Advisory Committee for the State of Minnesota in 2012 from the Builders Association of Minnesota reports that recently built homes in Minnesota had an average air leakage of 1.7 ACH50, substantially better than required by any version of the IECC. Additional analysis is conducted assuming 1.7 ACH50 rate for the current Minnesota state code, the 2009 IECC, and the 2012 IECC.

\section{C.6 Montana}

Montana has only one climate zone (climate zone 6) as defined by the IECC. The Montana State energy code is based on the 2009 IECC with some minor modifications. It requires a fenestration

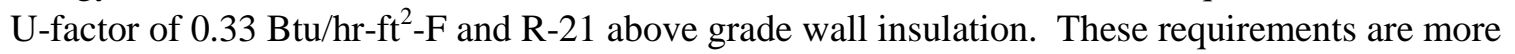
stringent than the fenestration and above grade wall insulation requirements in the 2009 IECC. This analysis assesses the cost effectiveness of the 2012 IECC over the Montana State energy code.

\section{C.7 Oklahoma}

Oklahoma has two climate zones (climate zone 3 and 4) as defined by the IECC. Oklahoma has adopted the 2009 International Residential Code (IRC). The 2009 IRC requires a glazed fenestration solar heat gain coefficient (SHGC) of 0.35 in climate zone 3. This glazed fenestration SHGC requirement for climate zone 3 is 0.30 in the 2009 IECC. This analysis assesses the cost effectiveness of the 2012 IECC over the Oklahoma state energy code. 


\section{C.8 Virginia}

Virginia has only one climate zone (climate zone 4) as defined by the IECC. The Virginia state code is based on the 2009 IECC but does not require duct pressure testing. This analysis assesses the cost effectiveness of the 2012 IECC over the Virginia state energy code by assuming no savings and no incremental costs from duct sealing requirement in 2009 IECC.

\section{C.9 Vermont}

Vermont has only one climate zone (climate zone 6) as defined by the IECC. The Vermont state energy code is based on the 2009 IECC with a number of modifications. The Vermont Energy Code has four packages in the "Fast Track" compliance method. This analysis assesses the cost effectiveness of the 2012 IECC over package 1 of the Vermont State Energy Code, which has many of the same prescriptive requirements as the 2009 IECC but with a few differences. This analysis accounts for the following modifications to the 2009 IECC:

- The fenestration U-factor requirement in the Vermont Energy Code is 0.32 instead of the 2009 IECC requirement of 0.35 .

- Slab perimeter insulation is required to be R-15 instead of the IECC's R-10.

- The maximum allowable duct leakage rates are lower than allowed by the 2009 IECC.

The Vermont code requires mechanical ventilation with fan capacity dependent on whether the system is flow tested. If the flow-rate is verified by testing, the Vermont code would require a 60-cubic feet per minute ( $\mathrm{cfm}$ ) fan for the three-bedroom home analyzed here. An untested system would have to be rated at $100 \mathrm{cfm}$. This analysis assumes $60 \mathrm{cfm}$ ventilation rate for the Vermont code for a singlefamily home and $45 \mathrm{cfm}$ for the multifamily building because it results in conservatively low estimates of energy savings and cost effectiveness for the 2012 IECC. The 2012 IECC also requires mechanical ventilation and the same ventilation rates are assumed for the 2012 IECC as for the state code.

The Vermont Energy Code has other differences from the IECC, such as special requirements for log homes and combustion safety requirements. Additionally, the fast track methods cannot be used if the glazing area is greater than $20 \%$ of the wall area. These differences are not examined in this analysis.

\section{C.10 Wisconsin}

Wisconsin has two climate zones (climate zone 6 and 7) as defined by the IECC. The Wisconsin State energy code is equivalent to the 2006 IECC with the following modifications:

- The 2006 IECC requires U-0.35 glazed fenestration whereas the Wisconsin state code requires U-0.30 glazed fenestration.

- The 2006 IECC requires R-10 basement walls whereas the Wisconsin state code requires R-15 basement walls.

- The 2006 IECC requires R-19 above-grade walls in Zone 6 and R-21 in Zone 7 whereas the Wisconsin state code requires R-21 above-grade walls for the entire state 
This analysis assesses the cost effectiveness of the 2009 and 2012 IECC over the Wisconsin State Energy Code. 



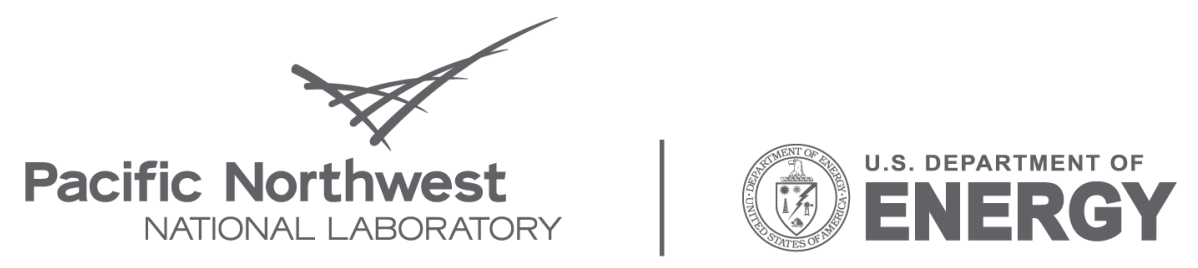

Proudly Operated by Battelle Since 1965

902 Battelle Boulevard

P.O. Box 999

Richland, WA 99352

1-888-375-PNNL (7665)

www.pnl.gov 